\title{
PERFORMANCE OF A CATCH BASIN FILTER AND LEACHATE FROM BIOCIDAL MEDIA FOR STORMWATER TREATMENT
}

\author{
A Master's Thesis Presented to the Faculty of \\ California Polytechnic State University \\ San Luis Obispo
}

\author{
In Partial Fulfillment of \\ the requirements for the degree of \\ Master of Science in \\ Civil and Environmental Engineering
}

By

Ryan Scott MacLure

March 2009 
(C) 2009

Ryan Scott MacLure

ALL RIGHTS RESERVED 


\section{COMMITTEE MEMBERSHIP}

TITLE:

AUTHOR:

DATE SUBMITTED:

COMMITTEE CHAIR:

COMMITTEE MEMBER:

COMMITTEE MEMBER:
Performance of a Catch Basin Filter and Leachate from Biocidal Media for Stormwater Treatment

Ryan Scott MacLure

March 2009

Dr. Ben Burgoa, Ph.D.

Dr. Tryg Lundquist, Ph.D. 


\title{
ABSTRACT \\ Performance of a Catch Basin Filter and Leachate from Biocidal Media for Stormwater Treatment
}

\author{
Ryan MacLure
}

The feasibility of installing biocidal beads into a catch basin filter insert for simultaneous stormwater disinfection and contaminant removal was tested. The catch basin filter insert $\left(\operatorname{DrainPac}^{\circledR}\right)$ was tested for its sediment, oil and grease, and coliform bacteria removal efficiency in conjunction with bench-scale testing of biocidal polymer beads. DrainPac ${ }^{\circledR}$ catch basin filters are composed of a metal frame, polypropylene filter fabric, and a highdensity polymer support basket, and are installed below storm drains. A 12 x 41 in. DrainPac ${ }^{\circledR}$ filter (United Stormwater, Inc.) insert was set in a flume that simulated a large-scale catchment basin. Pond water was gravity fed to the flume at flow rates up to $200 \mathrm{gpm}$. The pond water contained fine sediments at concentrations ranging from 30-50 $\mathrm{mg} / \mathrm{L}$. The biocidal beads were tested in a small laboratory column for potential application to stormwater treatment.

The head loss through the clean filter insert varied from $0.5 \mathrm{~cm}$ at $20 \mathrm{gpm}$ to $9.1 \mathrm{~cm}$ at $200 \mathrm{gpm}$. Head loss of $21.5 \mathrm{~cm}$ occurred after $625 \mathrm{~g}$ of solids were added to the filter at $200 \mathrm{gpm}$ at which point water began bypassing the filter fabric and flowing through the mesh screen. The highest flow rate that could be filtered through the loaded filter was 80 gpm. 
The DrainPac ${ }^{\circledR}$ filter removed total suspended solids with efficiencies ranging from $83 \%$ to $91 \%$ at flow rates of 20 to 200 gpm, with higher removal efficiencies at lower flow rates. The oil and grease removal efficiency of the DrainPac ${ }^{\circledR}$ filter ranged from $40 \%$ to $82 \%$. The DrainPac ${ }^{\circledR}$ filter exhibited no removal of coliform bacteria under these test conditions.

Biocidal brominated polystyrene beads, developed by Dr. S. D. Worley at Auburn University, were tested in a 1-cm diameter laboratory column apparatus for leaching of bromine compounds, which is important for determining if the filters will meet water quality regulations of the receiving waters. Removal efficiencies of coliform bacteria were tested in a companion study by Cal Poly graduate student Alex Bowerman. Pond water was passed through a 1-cm thick bed of beads in an up-flow direction. Leachate was analyzed for bromine, bromide, and bromoform. Leaching from both 0.3-mm and 0.8-mm biocidal beads was tested in the column apparatus. Samples collected for bromoform analysis were quenched with sodium thiosulfate, and the time before samples were quenched had a drastic effect on bromoform concentrations. Samples quenched after the collection of the total sample were assumed to be the most realistic for stormwater conditions since stormwater entering catch basins isn't immediately discharged into its receiving waters. Effluent from a $1-\mathrm{cm}$ bed of $0.3-\mathrm{mm}$ beads at 0.56 $\mathrm{mL} / \mathrm{sec}$ contained the following average concentrations: $0.47 \mathrm{mg} / \mathrm{L}$ bromine, $2.45 \mathrm{mg} / \mathrm{L}$ bromoform, and $0.53 \mathrm{mg} / \mathrm{L}$ bromide. The same conditions for $0.8 \mathrm{~mm}$ beads resulted in effluent containing the following average concentrations: $0.27 \mathrm{mg} / \mathrm{L}$ bromine, $0.06 \mathrm{mg} / \mathrm{L}$ bromoform, and $0.50 \mathrm{mg} / \mathrm{L}$ bromide. The much lower concentrations of bromine measured in the $0.8-\mathrm{mm}$ bead leachate was likely due to the greater surface area of the 
smaller beads. The greater leaching of bromoform from the $0.3 \mathrm{~mm}$ beads may be partly attributed to the greater surface area of the smaller beads, but also the manufacturer of the beads reported that different production methods were used for the $0.3 \mathrm{~mm}$ beads.

Higher bromine compound concentrations were found at lower flow rates, due to the longer contact times with the beads.

Deionized (DI) water that was used to initially wet the biocidal beads before passing pond water through the column was also analyzed for bromoform. The DI flush water from the $0.3 \mathrm{~mm}$ beads contained $1.25 \mathrm{mg} / \mathrm{L}$ bromoform at a flow rate of $0.28 \mathrm{~mL} / \mathrm{sec}$. Bromoform concentrations in the DI flush water from the $0.8 \mathrm{~mm}$ beads at the same flow rate were below detection. Bromoform is expected to be formed as bromine is reduced to bromide by the presence of organics. Since there are no organics present in DI water to form such high concentrations of bromoform as those found from the $0.3-\mathrm{mm}$ bead DI flush water, it appears that bromoform could have leached from the surface of the $0.3 \mathrm{~mm}$ beads.

The longevity of the bromine treatment of the biocidal beads was tested on one set of 0.3 $\mathrm{mm}$ beads by simulating five use cycles, and also by testing another set of beads after dry storage. Each use cycle was simulated by pumping pond water through a $1-\mathrm{cm}$ bed of 0.3 $\mathrm{mm}$ beads at $0.56 \mathrm{~mL} / \mathrm{sec}$ for one hour and then connecting the column to an air pump to dry for 23 hours. After five simulated uses, leachate from the beads showed only a slight reduction in concentrations of bromine and bromide (21\% and $4 \%$ less than fresh beads, respectively), while the concentration of bromoform was nearly 100 times less. The drastic decrease in bromoform concentration suggests that after five simulated uses, much of the bromoform was exhausted or conditions for the formation of bromoform were no 
longer present. For the dry storage test, $0.3 \mathrm{~mm}$ beads were wetted with 1-L DI water and then stored dry for 162 days. Then pond water was pumped through the column at $0.56 \mathrm{~mL} / \mathrm{sec}$ and the leachate was analyzed. After dry storage for 162 days, the leachate showed no reduction in bromine concentrations compared to fresh beads, a 97\% reduction in bromoform, and a $30 \%$ increase in bromide concentrations. This significant reduction in bromoform could be due to the volatilization of bromoform off the surface of the $0.3 \mathrm{~mm}$ beads during dry storage. The $0.3 \mathrm{~mm}$ beads are no longer being manufactured, and leachate from the $0.8 \mathrm{~mm}$ beads contained bromoform at concentrations below the potable drinking water maximum contaminant level of $80 \mu \mathrm{g} / \mathrm{L}$. Under all tested conditions, bromine, bromide, and bromoform are present in the leachate from the biocidal beads, and thus their applicability for stormwater disinfection depends on the longevity of the bromine compounds in receiving waters, and on the regulations governing these compounds. 


\section{ACKNOWLEDGMENTS}

This project was funded by United Stormwater Inc. I would like to thank Israel Rabinowitz, Tony Baird, and Ed Perry for all their technical support and for making this research possible.

I would also like to thank Dr. Yarrow Nelson for all of his knowledge, support, and friendship throughout this project as well as my time spent at Cal Poly. His passion and motivation for teaching is truly inspiring. Much gratitude to Dr. Ben Burgoa for keeping the jokes flowing in our meetings but also keeping us focused on reality.

I would like to thank Alex Bowerman for keeping me company during those long walks across campus, tireless hours in the lab, numerous board meetings, and the great stormwater site visit to Costa Rica. I would also like to thank Ian Woertz for the good company and endless support in the lab. I would have never been able to troubleshoot the IC without him. Much gratitude to Sarah Bragg-Flavan for showing me the way with extractions and the GC.

And finally, I would like to thank my family, friends, and Yvonne for their endless support throughout my college years. 


\section{TABLE OF CONTENTS}

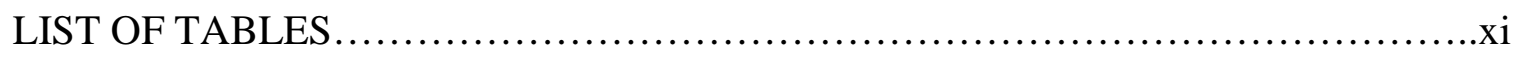

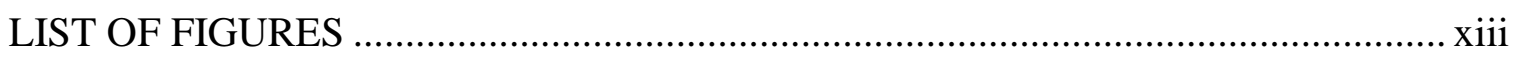

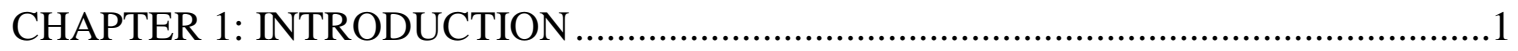

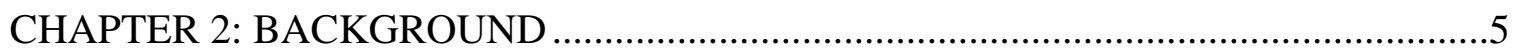

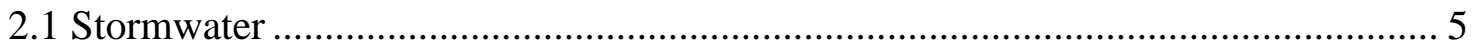

2.1.1 Issues with Stormwater......................................................................... 5

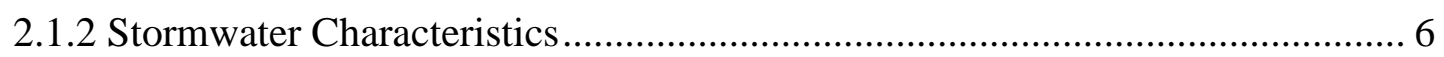

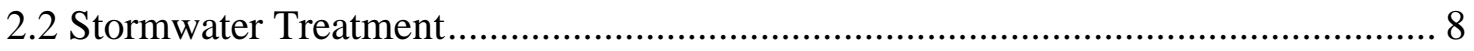

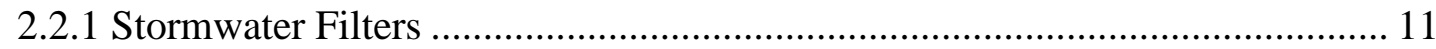

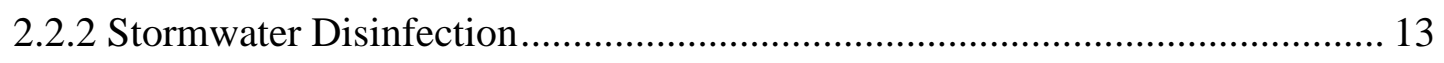

2.3 Biocidal Polymer Beads ................................................................................ 14

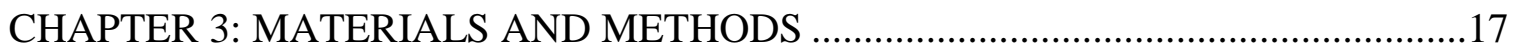

3.1 DrainPac ${ }^{\circledR}$ Stormwater Filter Testing............................................................. 17

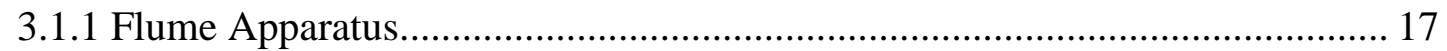

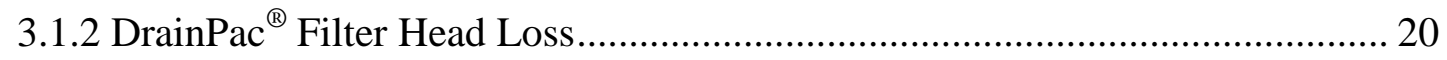

3.1.3 Suspended Solids Removal .................................................................... 21

3.1.4 DrainPac ${ }^{\circledR}$ Oil and Grease Removal ................................................................ 24

3.15 Testing Coliform Removal by a Full-Scale DrainPac ${ }^{\circledR}$ Filter............................. 26

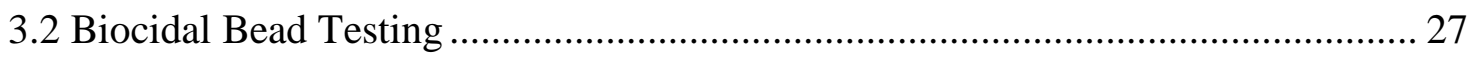

3.2.1 Column Apparatus ..................................................................................... 27

3.2.2 Column Head Loss Testing ...................................................................... 28

3.2.3 Measurement of Leaching …………………….......................................... 30

3.2.4 Bromine Sample Collection and Analysis ......................................................... 30

3.2.5 Bromoform Sample Collection and Analysis ……………………………...... 32

3.2.6 Bromide Sample Collection and Analysis.......................................................... 38

3.2.7 Measurement of Bromine Leaching During Longevity Testing ...................... 40

CHAPTER 4: RESULTS AND DISCUSSION............................................................

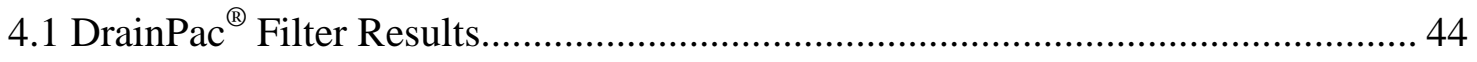

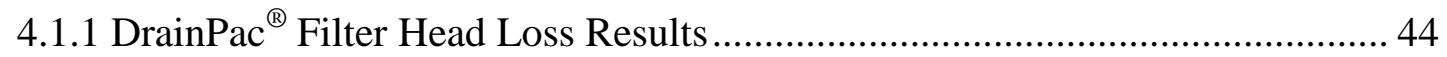


4.1.2 Sediment Removal by the Full-Scale DrainPac ${ }^{\circledR}$ Filter................................. 47

4.1.3 Oil and Grease Removal by the Full-Scale DrainPac ${ }^{\circledR}$ Filter ......................... 49

4.1.4 Coliform Removal by the Full-Scale DrainPac ${ }^{\circledR}$ Filter ................................. 51

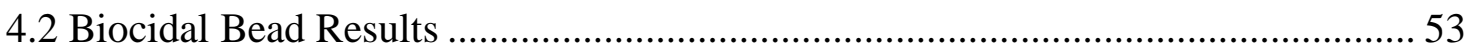

4.2.1 Laboratory Column and Biocidal Bead Head Loss Results ............................ 53

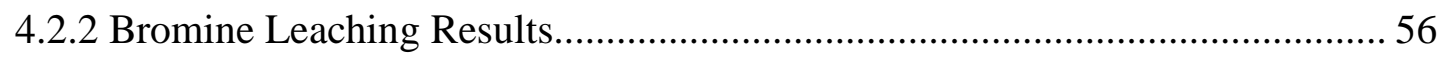

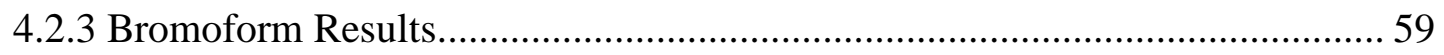

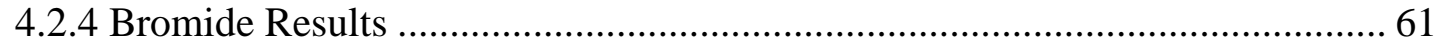

4.2.5 Bromine Compound Leaching During Longevity Testing ............................. 64

CHAPTER 5: CONCLUSIONS AND RECCOMENDATIONS ......................................70

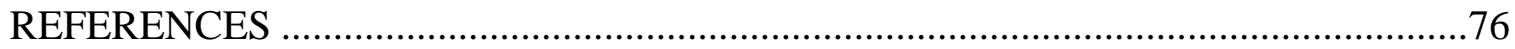

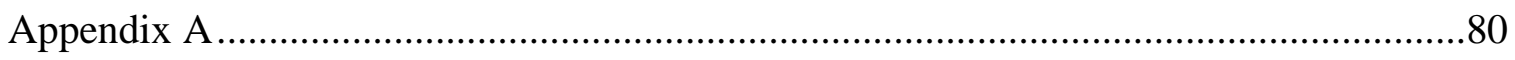




\section{LIST OF TABLES}

Table 1. Stormwater characteristics compared to rainfall and wastewater (Metcalf \&

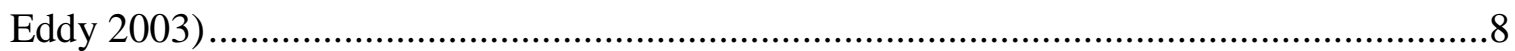

Table 2. Sieve analysis of sediment used for all DrainPac ${ }^{\circledR}$ solids tests...........................22

Table 3. Laboratory column and 12 x 41 in. DrainPac ${ }^{\circledR}$ filter equivalent flow rates.........29

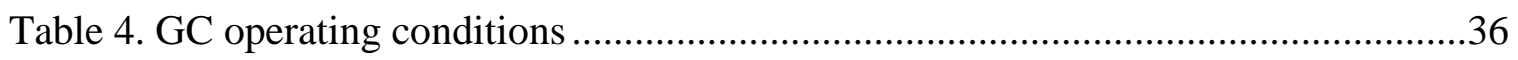

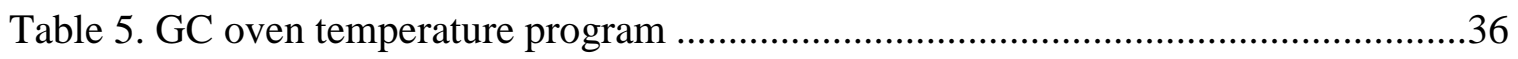

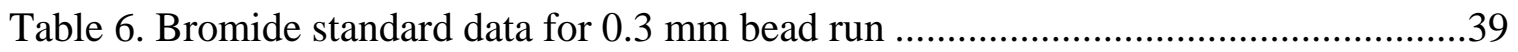

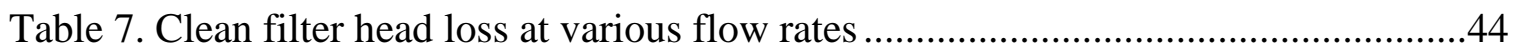

Table 8. Head loss of DrainPac ${ }^{\circledR}$ filter at $200 \mathrm{gpm}$ during solids loading (40 g/min) ......46

Table 9. Influent and effluent TSS measurements for DrainPac ${ }^{\circledR}$ filter testing at various

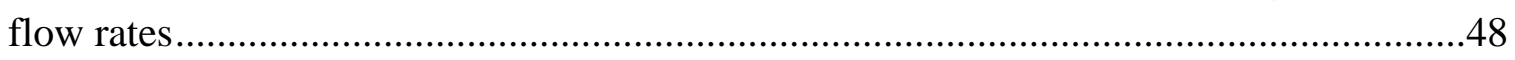

Table 10. DrainPac ${ }^{\circledR}$ filter sediment removal efficiency …..........................................48

Table 11. Oil concentration in water before and after DrainPac ${ }^{\circledR}$ filter at various flow

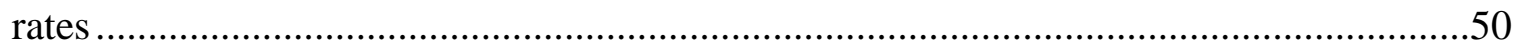

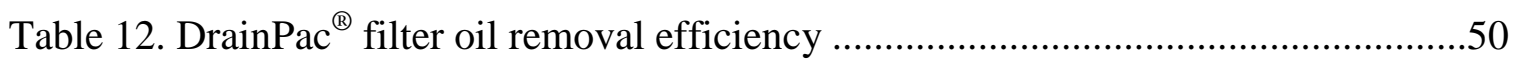

Table 13. DrainPac ${ }^{\circledR}$ filter coliform removal results at various flow rates .......................52

Table 14. $0.3 \mathrm{~mm}$ Biocidal bead head loss results ........................................................53

Table 15. $0.8 \mathrm{~mm}$ Biocidal bead head loss results .........................................................54

Table 16. Effluent bromine concentrations from the laboratory column with $0.3 \mathrm{~mm}$

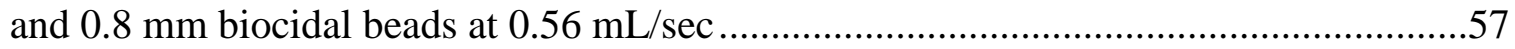

Table 17. Effluent bromoform concentrations from $0.3 \mathrm{~mm}$ biocidal beads ....................60

Table 18. Effluent bromoform concentrations from $0.8 \mathrm{~mm}$ biocidal beads ....................61

Table 19. Effluent bromide concentrations from $0.3 \mathrm{~mm}$ biocidal beads at $0.56 \mathrm{~mL} / \mathrm{sec}$

Table 20. Effluent bromide concentrations from $0.8 \mathrm{~mm}$ biocidal beads at a $0.56 \mathrm{~mL} / \mathrm{sec}$ flow rate

Table 21. Effluent bromide concentrations from $0.8 \mathrm{~mm}$ biocidal beads at a

$0.28 \mathrm{~mL} / \mathrm{sec}$ flow rate

Table 22. Effluent bromine concentrations from $0.3 \mathrm{~mm}$ biocidal beads at $0.56 \mathrm{~mL} / \mathrm{sec}$ flow rate under simulated use longevity conditions 
Table 23. Effluent bromide concentrations from $0.3 \mathrm{~mm}$ biocidal beads at $0.56 \mathrm{~mL} / \mathrm{sec}$ flow rate under longevity conditions

Table 24. Effluent bromoform concentrations from $0.3 \mathrm{~mm}$ biocidal beads at $0.56 \mathrm{~mL} / \mathrm{sec}$ flow rate under longevity conditions. .65

Table 25. Effluent bromine concentrations from $0.3 \mathrm{~mm}$ beads at a flow rate of 0.56 $\mathrm{mL} / \mathrm{sec}$ after 162 days of dry storage.

Table 26. Effluent bromide concentrations from $0.3 \mathrm{~mm}$ beads after 162 days of dry storage .68

Table 27. Bromoform concentrations from $0.3 \mathrm{~mm}$ bead effluent at $0.56 \mathrm{~mL} / \mathrm{sec}$ after

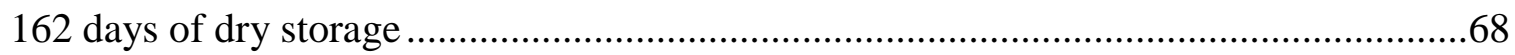

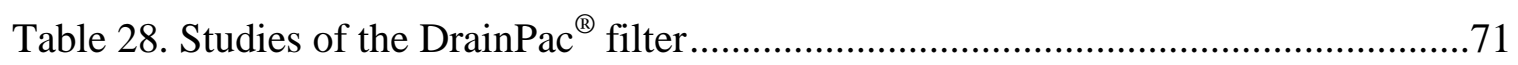

Table A-1. Bromide standard data for $0.8 \mathrm{~mm}$ bead run............................ 80 


\section{LIST OF FIGURES}

Figure 1. Stormceptor ${ }^{\circledR}$ on-site stormwater treatment device ........................................... 10

Figure 2. Structures of chlorinated and brominated polymeric beads

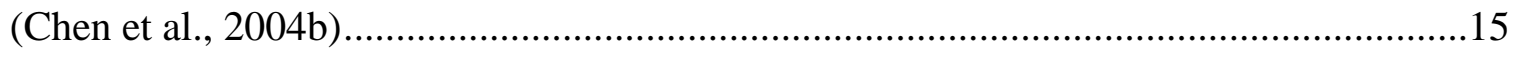

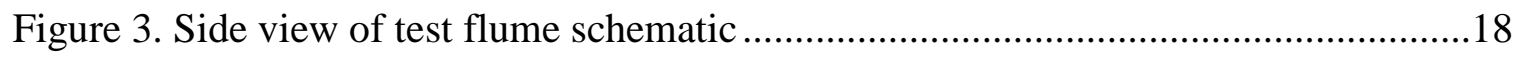

Figure 4. Photograph of test flume ......................................................................... 18

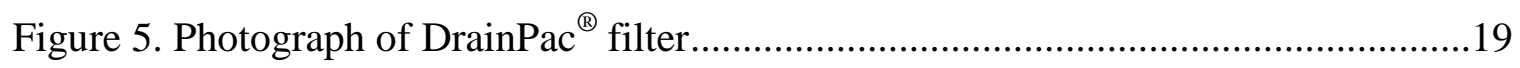

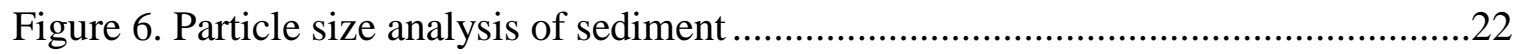

Figure 7. Photograph of column apparatus with manometer in-line for head loss testing (left) and biocidal beads packed in column apparatus (right) ......................................28

Figure 8. Reaction of DPD reagent to diluted bromine samples ....................................32

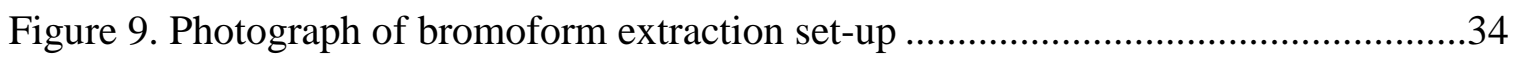

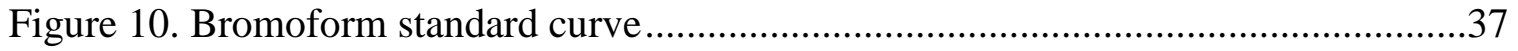

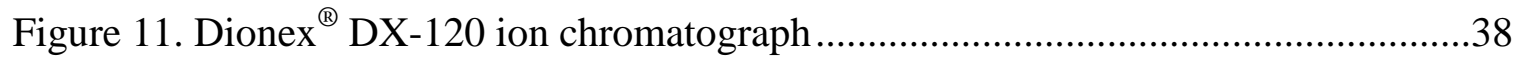

Figure 12. Bromide standard curve for $0.3 \mathrm{~mm}$ bead test........................................40

Figure 13. Simulated use cycle test apparatus with separate glass wool filter column .....41

Figure 14. Clean filter head loss at various flow rates............................................45

Figure 15. Head loss of DrainPac ${ }^{\circledR}$ filter at $200 \mathrm{gpm}$ during solids loading (40 g/min)...46

Figure 16. Head loss through DrainPac ${ }^{\circledR}$ filter loaded with 625 g solids compared to clean filter head loss.

Figure 17. DrainPac ${ }^{\circledR}$ filter sediment removal efficiency (error bars indicate standard deviations)

Figure 18. DrainPac ${ }^{\circledR}$ filter oil removal efficiency at various flow rates ...........................51

Figure 19. $0.3 \mathrm{~mm}$ Biocidal bead head loss results.....................................................54

Figure 20. $0.8 \mathrm{~mm}$ Biocidal bead head loss results.................................................55

Figure 21. Biocidal bead size and head loss comparison.............................................56

Figure 22. Bromine compound concentrations of fresh $0.3 \mathrm{~mm}$ biocidal bead effluent vs. $0.3 \mathrm{~mm}$ biocidal beads after five siumulated use cylces at $0.56 \mathrm{~mL} / \mathrm{sec}$ flow rate ......66

Figure 23. Bromine compound concentrations of fresh $0.3 \mathrm{~mm}$ bead effluent vs.

$0.3 \mathrm{~mm}$ bead effluent after 162 days of dry storage at $0.56 \mathrm{~mL} / \mathrm{sec}$ flow rate

Figure A-1. Bromide standard curve for $0.8 \mathrm{~mm}$ bead run 
Figure A-2. $5 \mathrm{mg} / \mathrm{L}$ bromide standard ion chromatogram.......................... 81

Figure A-3. Ion chromatogram of leachate from $0.8 \mathrm{~mm}$ beads at $0.28 \mathrm{~mL} / \mathrm{sec}-$ pond

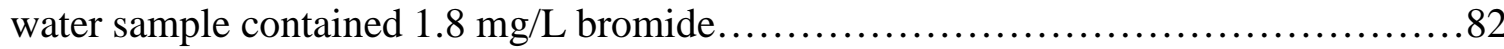

Figure A-4. Bromoform standard curve for dry storage beads ........................82 


\section{CHAPTER 1: INTRODUCTION}

As human population and urbanization increase, stormwater pollution is becoming a serious threat to the water quality of receiving rivers, creeks, and the ocean. Nonpoint source pollution resulting from urban stormwater runoff is a major cause of poor water quality in receiving waters (Lehner et al., 2001). Nonpoint source pollution is responsible for $65 \%$ of all water pollution in the United States (Chiras, 2006). Urban stormwater often contains high concentrations of fecal indicator bacteria, causing over 5,000 beach closures in California in 2005 (He \& He, 2008).

Under the Clean Water Act, the National Pollutant Discharge Elimination System (NPDES) regulates stormwater discharges from industrial, construction, and municipal storm sewer systems. Many methods to comply with NPDES requirements have been developed and continue to be researched. Stormwater contamination can be reduced with the use of structural and nonstructural Best Management Practices (BMPs) (Vassilios \& Hamid, 1997). Structural BMPs remove contaminants by intercepting stormwater flows and allowing solids and other contaminants to settle out, be filtered out, or adsorb to organic material (Horner and May, 1999). Common structural BMPs are: catch basin inlet filters, infiltration trenches, infiltration basins, porous pavement, detention basins, sand filters, and oil/grit separators (Vassilios \& Hamid, 1997). Nonstructural BMPs reduce the amount of stormwater contamination through street sweeping, education, and limiting the amount of impervious surfaces with land use planning (Vassilios \& Hamid, 1997). Low impact development (LID) is a technique to use stormwater BMPs to develop land without significantly altering the historical hydrology of the site (Dietz and 
Claussen, 2008). Onsite treatment is often implemented for larger industrial or construction sites, and it often involves proprietary systems that settle out solids, separate oils and grease, and adsorb heavy metals. Unfortunately, even with BMPs in place, stormwater pollution is still a problem.

The use of catch basin inlet filters is a simple, relatively inexpensive method to reduce stormwater contamination (Walch et al., 2004). United Stormwater Inc. produces $\operatorname{DrainPac}^{\circledR}$ stormwater filters, which are custom manufactured for each inlet and consist of a metal frame, a high-density polymer support basket, and a polypropylene filter cloth. United Stormwater Inc. provided a grant to Cal Poly to test the filter's sediment, oil and grease, and coliform bacteria removal efficiencies. The efficacy of the DrainPac ${ }^{\circledR}$ stormwater filter for removing sediment, oil and grease, and coliform bacteria was tested in a full-scale mock catch basin, constructed of wood, at the Cal Poly Irrigation and Training Research Center (ITRC). Water was gravity fed to the test apparatus from a pond at Cal Poly, San Luis Obispo.

In a past study conducted by Dr. Stenstrom of UCLA (Stenstrom, 1998), DrainPac ${ }^{\circledR}$ stormwater filters were tested for the removal of oil and grease, suspended solids, and polycyclic aromatic hydrocarbons (PAHs). Using the solids provided by United Pumping Service Inc., Dr. Stenstrom reported an average total suspended solids removal efficiency of $96 \%$ and an average oil and grease removal efficiency of 67\% (Stenstrom, 1998). Other studies on the performance of stormwater inlet filters have been conducted in the field; however, many of these studies have produced highly variable data, likely because of the high maintenance requirements of the filters, such as the removal of accumulated debris, and their design of bypassing flow once clogged (Walch et al., 2004). 
In addition to testing the DrainPac ${ }^{\circledR}$ stormwater filter, biocidal brominated polystyrene beads were tested for their application to stormwater treatment. These beads were originally developed in the laboratories of Dr. S.D. Worley (Sun et al., 1996). Similar beads (with chlorine treatment instead of bromine treatment) were tested by Sun et al. (1996) by passing deionized (DI) water at $0.7 \mathrm{~mL} / \mathrm{min}$ through $0.91 \mathrm{~g}$ of chlorinated biocidal polystyrene beads held in a Pasteur pipette. Concentrations of viable bacteria were reduced by six orders of magnitude, and the leachate contained less than $0.5 \mathrm{mg} / \mathrm{L}$ free chlorine and chloroform at concentrations ranging from 9- $16 \mu \mathrm{g} / \mathrm{L}$ (Sun et al., 1996). In a study using brominated polystyrene beads in a column, less than $2.0 \mathrm{mg} / \mathrm{L}$ free bromine was detected in the effluent water (Chen et al., 2003). Concentrations of bromoform in the effluent water were not reported. Worley et al. (1996) found chloroform concentrations from chlorinated beads to be below the potable water maximum contaminant level (MCL) of $100 \mathrm{ppb}$, and by analogy it was hoped that bromoform concentrations in leachate from this study would be below the potable water MCL of $80 \mathrm{ppb}$ (US EPA, 2008c). Thus it is important that leachate of bromoform be determined before these beads are deployed for stormwater applications.

United Stormwater Inc. requested the investigation of the use of biocidal beads in DrainPac $^{\circledR}$ stormwater filters to provide a stormwater inlet filter that inactivates bacteria as well as removing solids and oils. In the companion study mentioned above, the coliform removal efficiencies of the biocidal beads were tested by Alex Bowerman under various conditions. In the present research, the biocidal beads were evaluated for their leaching of bromine, bromide, and bromoform. This leaching is of particular interest if the beads are to be used for stormwater disinfection applications because their feasibility 
could depend on the regulatory limits on discharge of bromine compounds to receiving waters. The longevity of the beads is also of interest, and this research investigates the concentration of bromine compounds leaching from the beads after five simulated use cycles and after over five months of dry storage. The longevity of the beads is important for their application to stormwater disinfection because they must be able to withstand periods of wet and dry conditions in the stormwater filter.

To test the brominated beads, a glass laboratory column was constructed with a $1-\mathrm{cm}$ inside diameter. To model a 1-cm thick layer of biocidal beads at the bottom of a DrainPac ${ }^{\circledR}$ filter, the column was packed with a 1-cm bed depth of beads. Pond water was pumped in an up-flow direction through the beads. Influent and effluent coliform counts were measured in the companion study. For this study, effluent water was analyzed for bromine using a colorimetric $\mathrm{Hach}^{\circledR}$ kit, bromide was measured with ion chromatography, and bromoform was measured with gas chromatography using a mass spectrometer detector. The leachate from both $0.3 \mathrm{~mm}$ and $0.8 \mathrm{~mm}$ biocidal beads were tested for the aforementioned bromine compounds.

This project was designed as a joint research project between Ryan MacLure and Alex Bowerman. Construction of the full-scale mock catch basin and all DrainPac ${ }^{\circledR}$ filter testing was conducted together. The biocidal beads were tested in a bench-top column apparatus for their inactivation of bacteria by Alex Bowerman and the leaching of bromine compounds was tested by Ryan MacLure. In addition, the long-term biocidal effectiveness of the beads was tested by Alex Bowerman, and the leaching characteristics after multiple, simulated use cycles was tested by Ryan MacLure. 


\section{CHAPTER 2: BACKGROUND}

\subsection{STORMWATER}

Stormwater is water that flows through or over landscape during or after a rain or snowstorm event. For the purpose of this study, stormwater will be referred to as water that flows over or through man-made structures such as pipes, gutters, concrete canals, pavement, etc. In natural watersheds, not impacted by humans, stormwater infiltrates into the groundwater and excess water flows with its destination subject to the natural gradient of the land. Stormwater in natural environments is generally clean, and what nutrients and contaminants are present, are often treated by microbes in the soil during groundwater infiltration (Horner, 1993). It is in urban environments where stormwater contamination becomes an issue.

\subsubsection{Issues with Stormwater}

In urban environments, impervious surfaces inhibit stormwater from infiltrating into the groundwater and being treated by microbes in the soil. Stormwater soil infiltration can remove many contaminants such as organics, metals, and PAHs (Murakami et al., 2008). The increase of impervious surfaces in urban environments increases the volume of stormwater run off, increases the peak flow rate, reduces stormwater infiltration, and reduces the time that runoff occurs (Brezonik and Stadelmann, 2002). In urban environments, stormwater flows with increased velocities over streets, pavement, and through pipes, picking up pollutants along the way. Man-made water conveyance 
structures often have smooth surfaces that allow the stormwater to pick up high velocities where they are eventually discharged directly into streams and creeks, often causing erosion and sedimentation, and eventually into the ocean or other receiving waters. A study by Hascic and $\mathrm{Wu}$ (2006) found a strong association of water quality degradation with urban and agricultural land use.

If a rainfall event has not occurred for an extended amount of time, pollutants can build up on impervious surfaces and be dislodged by the "first flush" rainfall event. The stormwater runoff contained in the beginning of the runoff volume often has much higher pollutant concentrations than later in the rainfall event because of the release of accumulated contaminants on impervious surfaces (Metcalf \& Eddy 2003). Lee et al. (2004) found water contaminant concentrations to be 1.2 to 20 times greater during the beginning of the rainy season compared to the end of the wet season with monitoring sites located throughout Los Angeles County.

\subsubsection{Stormwater Characteristics}

Stormwater characteristics vary depending on the surrounding environment, the degree of urbanization present, and the type of urban land use (Brinkmann, 1983 and Brezonik and Stadelmann, 2002). The majority of pollutants found in urban stormwater are generated by automobiles; other sources include: construction, animal waste, trash, agriculture, etc. (Brinkmann, 1985). Brinkmann (1985) described sources of atmospheric pollutants as either dry or wet deposition. Dry deposition can be the emissions of pollutants from cars, power plants, industry, etc., and wet deposition can be atmospheric pollutants transferred 
to the liquid phase by precipitation (Brinkmann, 1985). Pollutants commonly found in stormwater include: sediment, metals, hydrocarbons, pesticides, bacteria, organics, nitrogen, and phosphorus (US EPA, 1999). Booth and Jackson (1997) reported that when a watershed has at least $10 \%$ effective impervious area, there is a noticeable loss of physical and biological aquatic habitat function.

Kayhanian et al. (2002) characterized stormwater runoff at several Caltrans facilities including highways, park and rides, maintenance areas, etc. The average total suspended solids (TSS) of the stormwater runoff from various Caltrans facilities ranged from approximately 45-123 mg/L (Kayhanian et al. 2002). Table 1 shows that typical contaminant concentrations in stormwater are consistently higher than pollutant concentrations in rainfall water (Metcalf \& Eddy, 2003). Bacterial contamination has also been known to be present in stormwater and has contributed to the degradation of aquatic habitats. Typical stormwater runoff contains $10^{3}-10^{4} \mathrm{MPN} / 100 \mathrm{~mL}$ fecal coliform bacteria (Table 1, Metcalf\& Eddy, 2003). Urban stormwater runoff contributes a large amount of bacterial contamination to receiving waters, however, marine animals and waterfowl also contribute to the contamination especially around lagoons and estuaries (Noble et al., 2000). Ocean water quality sampled in close proximity to a stormwater outfall consistently had poor bacteriological water quality (Noble et al., 2000). With such high contaminant concentrations possible in urban stormwater, stormwater controls are necessary for protecting the water quality of receiving waters, the health of aquatic habitats, and the safety of the public. 
Table 1. Stormwater characteristics compared to rainfall and wastewater (Metcalf \& Eddy 2003)

\begin{tabular}{|c|c|c|c|c|c|}
\hline \multirow[b]{2}{*}{ Parameter } & \multirow[b]{2}{*}{ Unit } & \multicolumn{4}{|c|}{ Range of parameter concentrations } \\
\hline & & Rainfall $^{\mathrm{a}}$ & $\begin{array}{c}\text { Stormwater } \\
\text { Runoff }^{\text {b }}\end{array}$ & $\begin{array}{c}\text { Combined } \\
\text { wastewater }^{c}\end{array}$ & $\begin{array}{c}\text { Municipal } \\
\text { wastewater }\end{array}$ \\
\hline $\begin{array}{l}\text { Total suspended } \\
\text { solids, TSS }\end{array}$ & $\mathrm{mg} / \mathrm{L}$ & $<1$ & $67-101$ & $270-550$ & $120-370$ \\
\hline $\begin{array}{c}\text { Biological Oxygen } \\
\text { Demand, BOD }\end{array}$ & $\mathrm{mg} / \mathrm{L}$ & $1-13$ & $8-10$ & $60-220$ & $120-380$ \\
\hline $\begin{array}{c}\text { Chemical Oxygen } \\
\text { Demand, COD }\end{array}$ & $\mathrm{mg} / \mathrm{L}$ & $9-16$ & $40-73$ & $260-480$ & $260-900$ \\
\hline $\begin{array}{c}\text { Fecal coliform } \\
\text { bacteria }\end{array}$ & $\begin{array}{c}\mathrm{MPN} / 100 \\
\mathrm{~mL}\end{array}$ & & $10^{3}-10^{4}$ & $10^{5}-10^{6}$ & $10^{5}-10^{7}$ \\
\hline $\begin{array}{c}\text { Total Kjeldahl } \\
\text { Nitrogen }\end{array}$ & $\mathrm{mg} / \mathrm{L}$ & & $0.43-1.00$ & $4-17$ & 20-705 \\
\hline Nitrate & $\mathrm{mg} / \mathrm{L}$ & 0.05-1 & $0.48-0.91$ & & 0 \\
\hline Phosphorus & $\mathrm{mg} / \mathrm{L}$ & $0.02-0.15$ & $0.67-1.66$ & $1.2-2.8$ & $4-12$ \\
\hline Copper & $\mu \mathrm{g} / \mathrm{L}$ & & $27-33$ & & \\
\hline Lead & $\mu \mathrm{g} / \mathrm{L}$ & $30-70$ & $30-144$ & $140-600$ & \\
\hline Zinc & $\mu \mathrm{g} / \mathrm{L}$ & & $135-226$ & & \\
\hline \multicolumn{6}{|c|}{${ }^{a}$ Adapted from Huber (1984) } \\
\hline \multicolumn{6}{|c|}{${ }^{b}$ Adapted from US EPA (1983) } \\
\hline \multicolumn{6}{|c|}{${ }^{c}$ Adapted from Metcalf \& Eddy (1977) } \\
\hline
\end{tabular}

\subsection{STORMWATER TREATMENT}

Today, stormwater is treated in a variety of ways, often depending on the volume of water to be treated, site characteristics, and desired treatment level. Many stormwater treatment devices are used as part of construction Best Management Practices or BMP's that may be necessary to comply with National Pollutant Discharge Elimination System 
(NPDES) requirements. Under the Clean Water Act, the NPDES program was created in 1972 to control point-source discharges from municipal separate storm sewer systems (MS4s), construction activities, and industrial activities (US EPA, 2008b). Phase 1 of the NPDES system was created in 1990, and it regulates municipalities over 100,000 people and Phase 2 was created in 1999 to regulate small municipalities and construction sites disturbing one to five acres of land (US EPA, 2008b).

Since construction sites are now being regulated for their on-site stormwater, many onsite treatment technologies have been developed. One example of a proprietary on-site treatment technology is the Stormceptor ${ }^{\circledR}$ (Figure 1), which is marketed for industrial and commercial construction sites. The Stormceptor ${ }^{\circledR}$ by Imbrium Systems Corp. (Rockville, M.D.) is a hydrodynamic separator device that dissipates the energy of the stormwater and allows solids to settle to the bottom, oils and grease to rise and separate to the top, while treated stormwater is released (Imbrium Systems Corp., 2008). Some proprietary devices contain adsorbents to eliminate trace metals and hydrocarbons, but these require replacement after exhaustion (Devinny et al, 2005). The disadvantages of many proprietary on-site stormwater treatment devices are that many are designed to bypass treatment during high flows, maintenance is necessary, and installation costs are high (Devinny et al., 2005). While proprietary on-site treatment devices may prove adequate for large industrial or commercial sites, many municipalities are turning to BMPs to meet water quality standards and goals. 


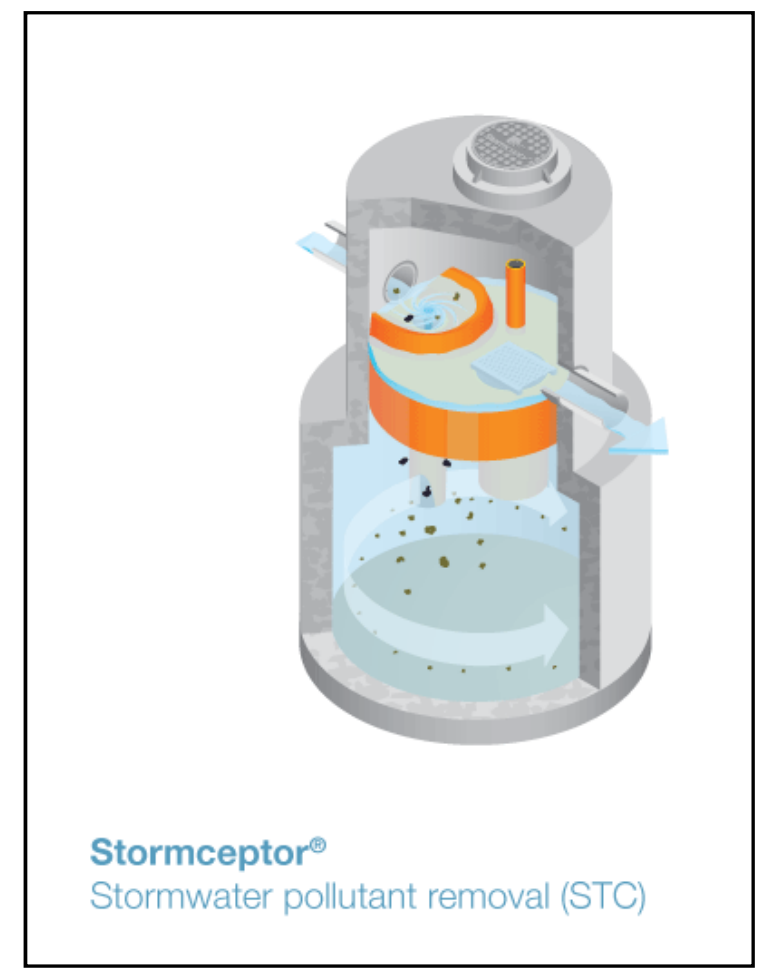

Figure 1. Stormceptor ${ }^{\circledR}$ on-site stormwater treatment device

Booth et al. (2002) reported that effective stormwater management cannot solely rely on structural stormwater BMPs such as stormwater detention, but the control of impervious surfaces must be incorporated into development to minimize impacts on aquatic habitats. Low impact development (LID) is a relatively new approach that incorporates stormwater management into the development of sites to treat stormwater on-site and minimize impervious surfaces (US EPA, 2008a). The goal of LID is to develop land without significantly altering the pre-development hydrology of the land by increasing imperviousness and increasing runoff volumes (Dietz and Claussen, 2008). Green spaces in parking lots, green roofs on commercial buildings, rain gardens, permeable pavement, and vegetated swales are all techniques used to reduce the amount of run-off by increasing stormwater infiltration into the groundwater (Lehner et al., 2001). 
LID reduces the amount of stormwater that enters municipal storm sewers, and some techniques can remove sediments, metals, and nutrients as water infiltrates through plants and soil (Lehner et al., 2001). Hatt et al. (2007) and Henderson et al. (2007) found that non-vegetated biofilters consisting of just soil, not including sand, are actually sources for nitrogen, and thus vegetation is required if nutrient removal is a goal. In a similar study, Bratieres et al. (2008) reported that any soil-based biofilter can remove total suspended soilds (TSS), however, if nutrient removal is desired, a sandy-loam biofilter media planted with $C$. appressa or M. ericifolia or other species with strong nutrient removal capacities is effective. Constructed wetlands for the treatment of urban and agricultural stormwater are of recent interest due to their natural tendencies to filter and absorb nutrients and other contaminants from water. One study found decreased contaminant concentrations in the effluent from a constructed wetland, created by the simple installation of an outlet weir to an existing dry detention pond and the growth of natural volunteer wetland species (Carleton et al., 2000).

\subsubsection{Stormwater Filters}

Stormwater filters or catch basin inserts are common approaches to reducing contaminants from stormwater that flows through catch basins (Morgan et al., 2005). Stormwater filters are typically installed at street level or below grade to control urban runoff (Hipp et al., 2006). Morgan et al. (2005) tested several catch basin inserts in a stormwater simulator, including the DrainPac ${ }^{\circledR}$ filter (the type used in the present study), for removal of total suspended solids (TSS) and total petroleum hydrocarbons (TPH). This study found decreasing TSS removal efficiency as the amount of water filtered 
increased (Morgan et al., 2005). This study used sediment from street sweepings and fed a $225 \mathrm{mg} / \mathrm{L}$ influent TSS concentration into the catch basin inserts (Morgan et al., 2005). Each insert was tested for 30 minutes at flow rates of 207 to 213 gpm, and Morgan et al. (2005) found that the DrainPac ${ }^{\circledR}$ filter had an average TSS removal efficiency of approximately $25 \%$.

The Civil and Environmental Engineering Department of the University of California, Los Angeles, conducted a test for United Pumping Service, Inc. testing the DrainPac ${ }^{\circledR}$ filters for head loss, and removal of suspended solids, oil and grease, and polycyclic aromatic hydrocarbon (PAH) removal (Stenstrom, 1998). Their experimental setup included a mock catch basin where they could insert the filters, a stilling chamber, and a $10 \times 2 \mathrm{ft}$. flume constructed of plywood. The sediment removal test used trash and debris extracted from catch basins in southern California provided by United Pumping Service, Inc. that included sediment, cigarette butts, leaves, etc. (Stenstrom, 1998). The UCLA study found that the DrainPac ${ }^{\circledR}$ filter removed $95 \%$ to $98 \%$ of TSS at a flow rate of 75 gpm (Stenstrom, 1998). The UCLA study reported that the DrainPac ${ }^{\circledR}$ filter had a $49 \%$ to $86 \%$ removal efficiency of oil and grease, and that removal efficiency was lower at higher oil and grease concentrations, decreasing after the accumulation of oil and grease (Stenstrom, 1998).

In a study by Walch et al. (2004), the DrainPac ${ }^{\circledR}$ filter and various other catch basin inserts were installed in different locations in Delaware, and tested for their sediment and hydrocarbon removal capabilities. Nearby catch basins without insert filters were used as the control, to compare data to the catch basins containing inlet filters (Walch et al., 2004). The DrainPac ${ }^{\circledR}$ filter produced variable results, with some pollutant 
concentrations higher in the "protected" inlets than in the controls; however, this trend was not statistically significant (Walch et al., 2004). Further research of the DrainPac ${ }^{\circledR}$ filter's ability to remove solids, oils and greases, and coliforms was necessary to better understand the conflicting results of Stenstrom (1998) and Walch et al. (2004). The performance of many inlet filters often depends on the amount of maintenance provided to keep the filter unclogged and clean.

\subsubsection{Stormwater Disinfection}

High coliform bacteria concentrations are common in urban stormwater (Table 1), making onsite stormwater disinfection a possible method to reduce bacterial contamination of receiving waters. To date, there is little published research for the onsite disinfection of stormwater. However, several studies have investigated disinfection for combined sewer systems, which treat sanitary sewage as well as urban stormwater. When these combined systems exceed their treatable water capacity during storm events, combined sewer overflow (CSO) occurs, releasing untreated water into the receiving waters (US EPA, 2004). In a study by Thomas et al. (1990), combined stormwater and sanitary sewage was disinfected in a hydrodynamic separator with peracetic acid, but the required doses were very high. More research is required to determine the feasibility of using peracetic acid for water disinfection (Casson et al., 2006). One advantage of peracetic acid is that it biodegrades into hydrogen peroxide, acetic acid, and oxygen, which are relatively benign substances (Casson et al., 2006). The disadvantage is that it is a hazardous material, and is slightly unstable, requiring onsite generation (Casson et al., 2006). 
Although stormwater alone has not been disinfected onsite, CSO water has been disinfected by UV radiation treatment, ozone, chlorine, chlorine dioxide, etc. (Field et al., 1993). One issue with chlorine disinfection and other halogens is the formation of disinfection byproducts, necessitating dechlorination (Field et al., 1993).

\subsection{BIOCIDAL POLYMER BEADS}

Dr. S. D. Worley of Auburn University developed novel heterocyclic N-halamine biocidal disinfectants that have some advantages over current biocides in use today. Most biocidal materials currently in use consist of quaternary ammonium salt derivatives ("quats") and polymeric derivatives ("polyquats") (Chen et al., 2004a). These materials deactivate bacteria by penetrating the bacterial cell wall and releasing alkyl cations (Chen et al., 2004a). Quats and polyquats are stable in aqueous solution and have adequate disinfecting longevity, however, they cannot be reactivated once exhausted and require long contact times (Chen et al., 2004a).

Biocidal polymer beads composed of poly[1,3-dichloro-5-methyl-5-(4'vinylphenyl)hydantoin] and poly[1,3-dibromo-5-methyl-5-(4'-vinylphenyl)hydantoin] were developed and tested by Dr. Worley for their water disinfection properties (Chen et al., 2003). These N-halamine biocidal polymer beads can be activated with chlorine or bromine. Bacterial cells are reported to be deactivated upon contact with the halogen atom, and the release of free halogen into aqueous solution is less common than with quats or polyquats (Chen et al., 2004a). The stability of these compounds is due to their chemical structures (Figure 2), with electron-donating alkyl components adjacent to the $\mathrm{N}-\mathrm{Br}$ and $\mathrm{N}-\mathrm{Cl}$ functional groups, which control the release of free halogen (Chen et al., 
2003). Benefits of the $\mathrm{N}$-halamine biocides are that the halogen atom can be regenerated simply by exposure to free halogen and the required retention time for bacterial cell deactivation is less than for quats and polyquats (Chen et al., 2004a).

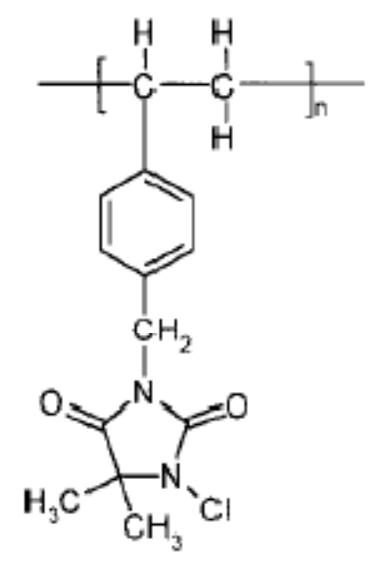

$\mathrm{PHY}-\mathrm{Cl}$

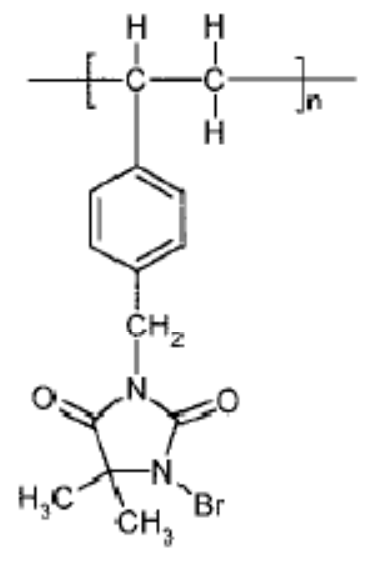

$\mathrm{PHY}-\mathrm{Br}$

\section{Figure 2. Structures of chlorinated and brominated polymeric beads (Chen et al., 2004b)}

These halogenated polymeric beads were tested for bacterial disinfection of water by passing water through a $1.3-\mathrm{cm}$ inside diameter, $7.6-\mathrm{cm}$ length column packed with brominated beads such that it contained an empty bed volume of $3.1 \mathrm{~mL}$ (Chen et al., 2003). Dr. Worley found that a 6.8-log reduction of the bacteria S. Aureus was possible with a 1 second or less contact time. Samples were plated to enumerate active bacteria after the effluent was quenched with $0.02 \mathrm{~N}$ sodium thiosulfate (Chen et al., 2003). The time elapsed before quenching was not reported. It was also found that free bromine concentrations in the effluent water were less than $2.0 \mathrm{mg} / \mathrm{L}$ (Chen et al., 2003).

The longevity of the beads was also tested in a similar column experiment by Dr. Worley, in which 3-L solution of E. coli $\left(10^{6} \mathrm{CFU} / \mathrm{mL}\right)$ in buffered demand-free water at $\mathrm{pH} 7.0$ 
was passed through a column of brominated beads for a five-day period. A six-log inactivation was observed for the entire length of the experiment (Sun et al., 1995). The amount of bromine in the effluent water in this experiment was not reported. Chen et al. (2004b) found that brominated polymer beads can deactivate bacteria with less contact time than the chlorinated polymer beads; however, the brominated beads can release free halogen more readily than the chlorinated beads. 


\section{CHAPTER 3: MATERIALS AND METHODS}

\subsection{DrainPaC ${ }^{\circledR}$ StORMWATER Filter Testing}

\subsubsection{Flume Apparatus}

The full-scale DrainPac ${ }^{\circledR}$ filter insert was tested using a flume constructed of wood and sealed with polyurethane (Figures 3 and 4). The bed slope was $2 \%$, the bed length was eight feet, and the bed width matched the width of the filter insert (41 inches). Water was gravity fed to the system from a pond located on the campus at Cal Poly, San Luis Obispo. The pond water was supplied by a six-inch diameter PVC pipe, which was then reduced to a diameter of four inches. Flow rate was monitored using a magnetic flow meter (Seametrics ${ }^{\circledR}$ ). Water entered the flume via a mixing chamber, which could be used to mix in additional contaminants (e.g. solids and oil). The mixing chamber was constructed by cutting twelve 1-inch diameter holes around the bottom sides of a 5-gallon HDPE bucket. At the higher flow rates of 150 GPM and 200 GPM, a perforated metal weir was added to the flume to slow the water velocity and prevent the water from overshooting the cloth portion of the DrainPac ${ }^{\circledR}$ filter. 


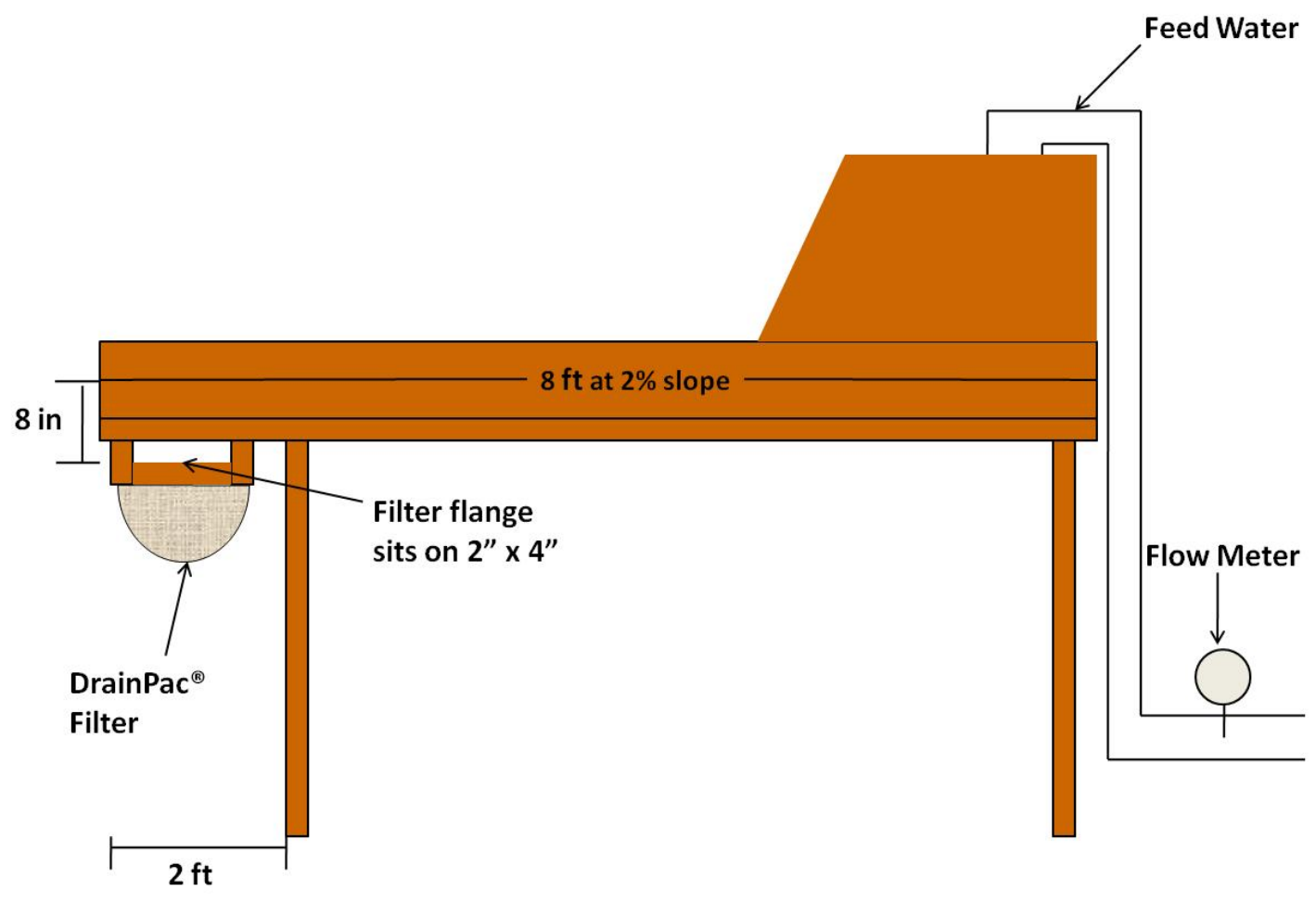

Figure 3. Side view of test flume schematic

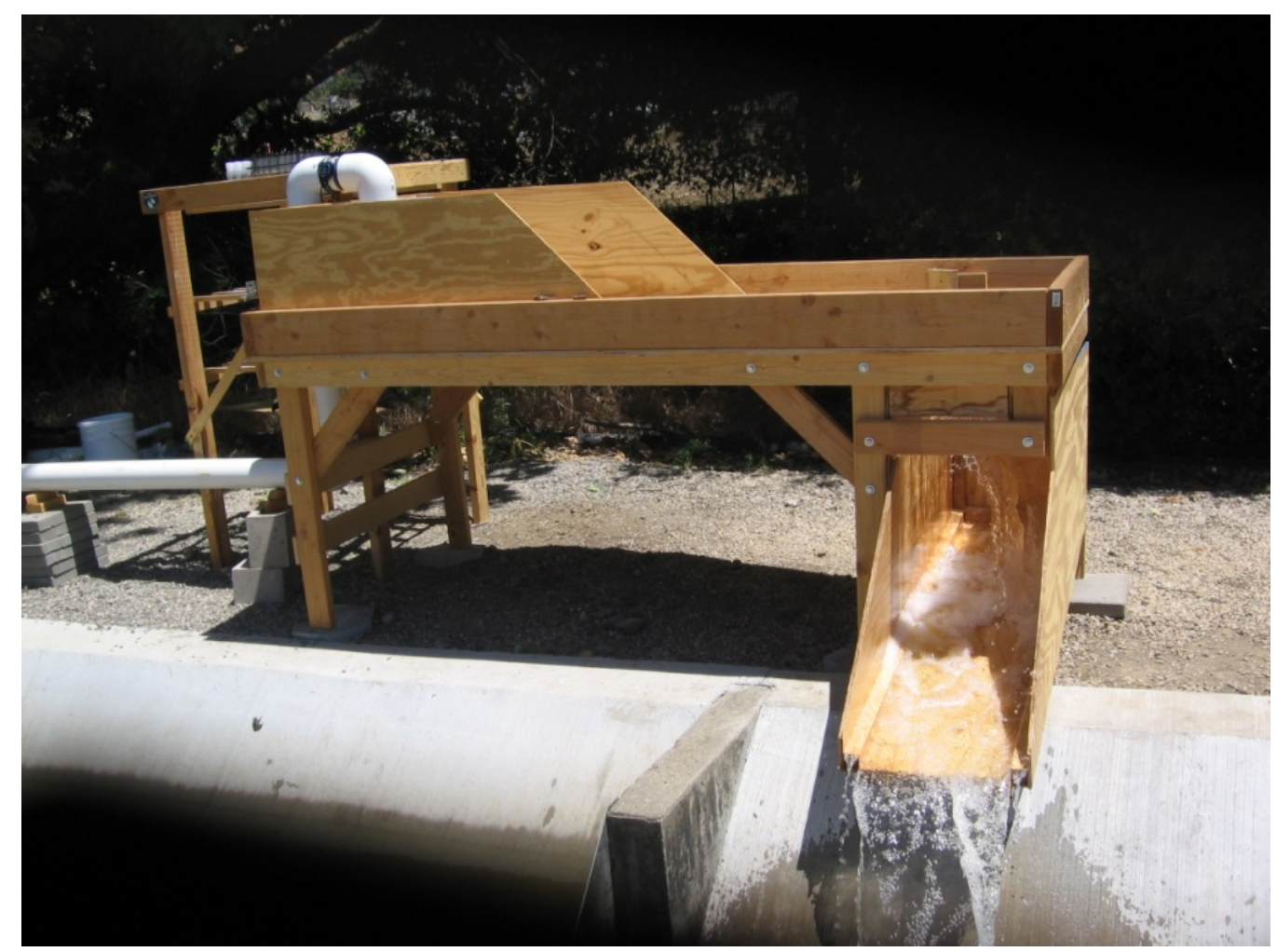

Figure 4. Photograph of test flume 
The DrainPac ${ }^{\circledR}$ filter used in our testing was provided by United Storm Water Inc.

(Figure 5). This type of filter was designed for inlet type storm drains. The dimensions for the stainless steel frame assembly were $12 \times 41$ in. The DrainPac ${ }^{\circledR}$ contained a nonwoven geotextile (polypropylene) filter liner that covered a 9-inch depth of the filter and a 3.5-inch PVC mesh for overflow by-bass (Figure 5).

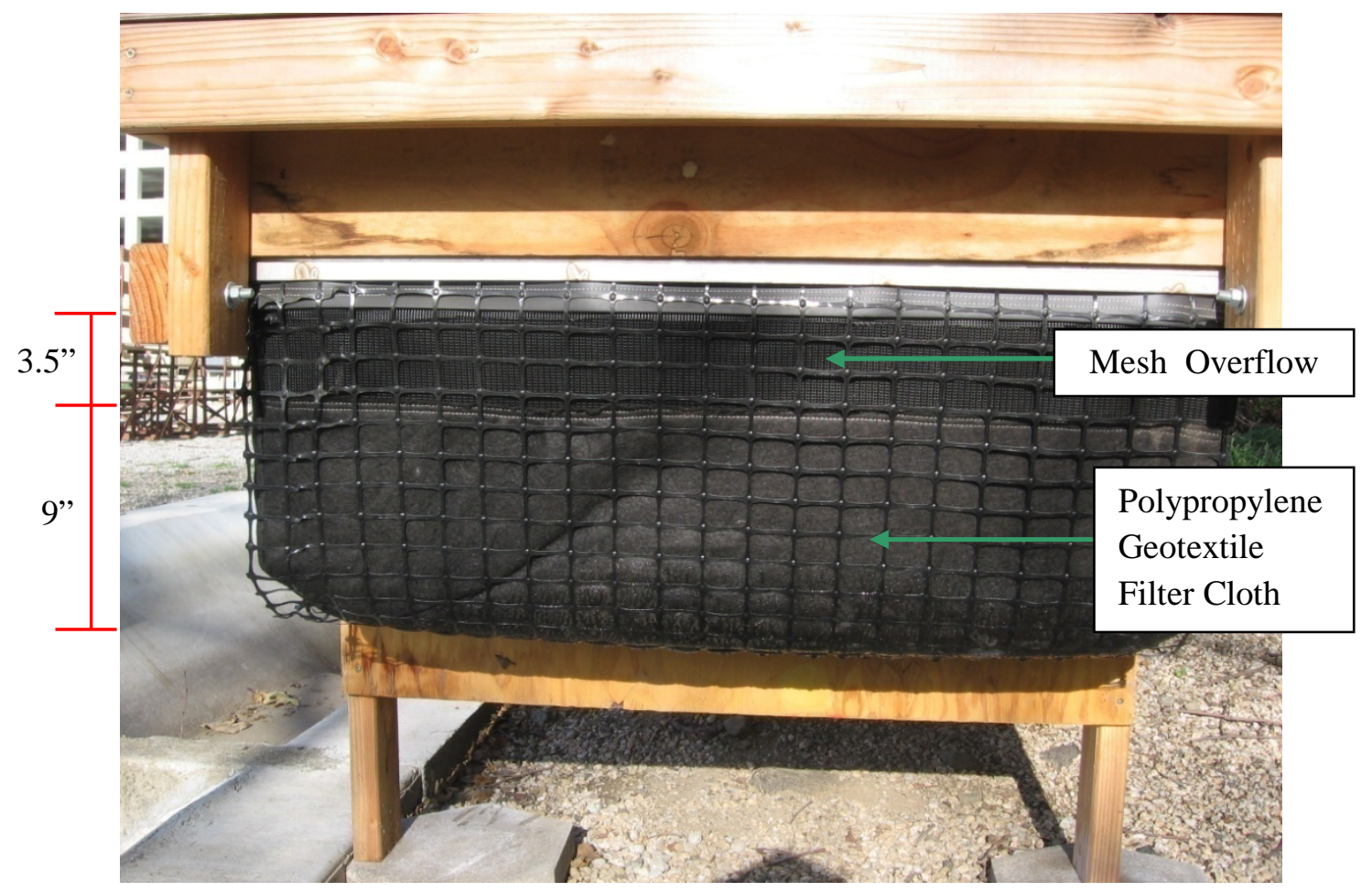

Figure 5. Photograph of DrainPac ${ }^{\circledR}$ filter 


\subsubsection{DrainPac ${ }^{\circledR}$ Filter Head Loss \\ Head Loss of Clean DrainPac ${ }^{\circledR}$ Filter}

The filter head loss was tested with a clean DrainPac ${ }^{\circledR}$ filter using pond water as the only source of solids (30-50 mg/L total suspended solids). The head loss was measured at flow rates of $20,50,115,150,175$, and 200 gpm. Once the desired flow rate was reached, head loss measurements were taken by measuring the water level from the same position in the bottom of the filter fabric. The head loss measurements were taken as swiftly as possible, with approximately two minutes passing between each measurement, to avoid developing a filter cake that could affect the head loss through the filter.

\section{DrainPac $^{\circledR}$ Filter Loading Test at 200 gpm}

The filter was loaded at $200 \mathrm{gpm}$ (superficial water velocity of $3.98 \mathrm{~cm} / \mathrm{sec}$ ) with a solids concentration of approximately $80-100 \mathrm{mg} / \mathrm{L}$ to determine the amount of solids that would cause the filter to overflow (overflowing the filter fabric and passing through the mesh screen). Since the pond water only contained $30-50 \mathrm{mg} / \mathrm{L}$ solids, an additional 40 $\mathrm{g} / \mathrm{min}$ solids was added to the mixing chamber as poorly graded sand (see Table 2 and Figure 6) to provide the target concentration of $80-100 \mathrm{mg} / \mathrm{L}$ solids (sieve analysis below). The volume of water that passed through the filter and the amount of solids added to the mixing chamber were recorded for each head loss measurement until the head loss became high enough that water began by-passing the filter. The total amount of solids loaded into the filter was calculated using the volume of water passed through the 
filter, the approximate solids concentration of the pond water, and the amount of solids added to the mixing chamber.

\section{Loaded DrainPac ${ }^{\circledR}$ Filter Head Loss}

The filter was considered fully loaded after the addition of solids from the previous test caused the filter to overflow at $200 \mathrm{gpm}$. With the solids left in the filter, the head loss of water through the loaded filter was measured at various flow rates, starting at 20 gpm until water began to overflow the filter and pass through the mesh. Head loss measurements were taken at each flow rate by measuring the water level from the same position in the bottom of the filter fabric and increasing the flow rate after each measurement until water began to overflow the filter.

\subsubsection{Suspended Solids Removal}

The suspended solids removal efficiency of the DrainPac ${ }^{\circledR}$ filter was tested at 20,60, 150, and $200 \mathrm{gpm}$. The filter was thoroughly cleaned with tap water before testing at each flow rate. After cleaning, the filter was installed into the flume and the flow of sedimentladen water was started. Poorly graded sand with less than 5\% fines along with solids naturally present in pond water was used for all tests. The results of a sieve analysis on the sand are displayed in Table 2 and Figure 6. From the sieve analysis, the coefficient of uniformity $(\mathrm{Cu})$ was 2.88 and the coefficient of curvature $(\mathrm{Cc})$ was 1.09 , corresponding to a poorly-graded sand classification (USCS ASTM D 2487). 
Table 2. Sieve analysis of sediment used for all DrainPac ${ }^{\circledR}$ solids tests

\begin{tabular}{|c|c|c|c|c|}
\hline Sieve No. & Sieve Size $(\mathrm{mm})$ & Weight Retained $(\mathrm{g})$ & \% Cumulative Retained & \% Passing \\
\hline 4 & 4.75 & 0 & 0.00 & 100.00 \\
\hline 10 & 2 & 0 & 0.00 & 100.00 \\
\hline 20 & 0.85 & 839.06 & 32.37 & 67.63 \\
\hline 40 & 0.425 & 1075.77 & 73.88 & 26.12 \\
\hline 60 & 0.25 & 431.66 & 90.53 & 9.47 \\
\hline 100 & 0.15 & 180.97 & 97.51 & 2.49 \\
\hline 200 & 0.075 & 48.24 & 99.38 & 0.62 \\
\hline & $<0.075$ & 16.19 & 100 & \\
\hline \multicolumn{2}{|r|}{ Total $=$} & 2591.89 & & \\
\hline
\end{tabular}

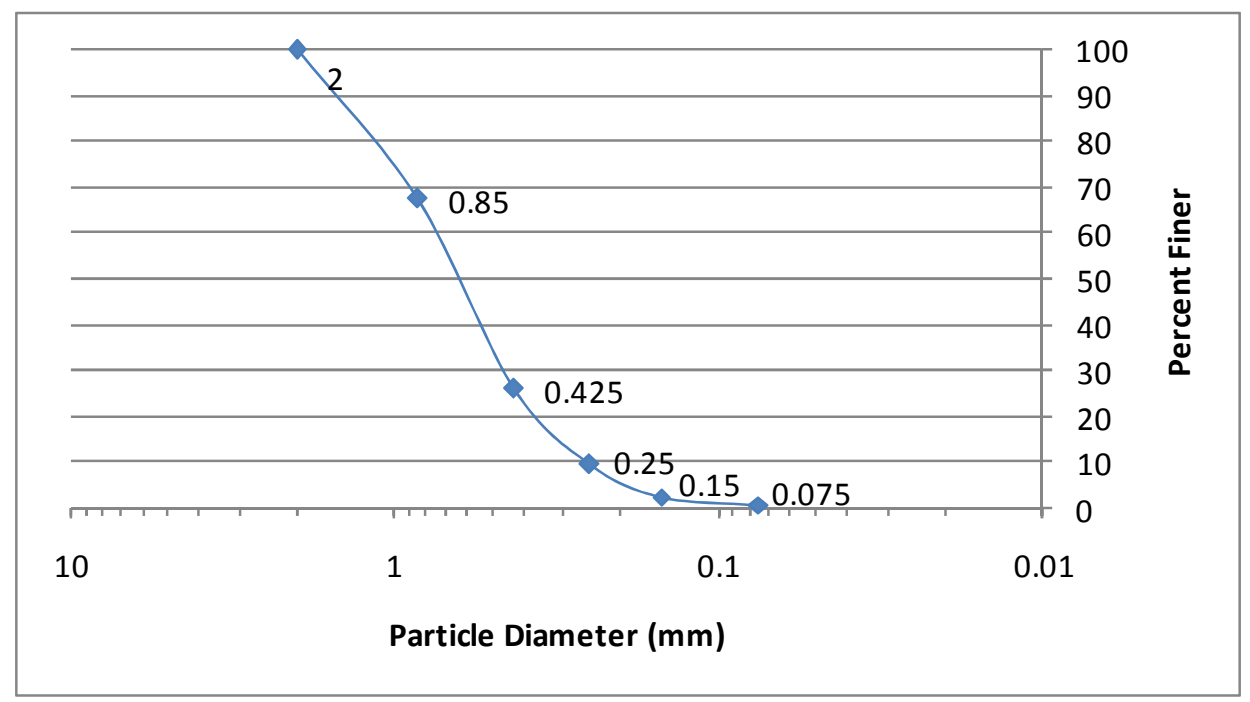

Figure 6. Particle size analysis of sediment

For each test, approximately 200 gallons of water was allowed to pass through the filter before samples were taken. Since the solids which build up in the bottom of the filter may affect removal efficiency, this uniform pre-loading was used for all tests at each flow rate. Three influent and three effluent samples were collected using clean $0.5-\mathrm{L}$ plastic sample bottles for each test. Each set of influent and effluent samples were 
collected simultaneously with one person collecting influent at the spillway before the water entered the DrainPac ${ }^{\circledR}$ filter and the other person collecting effluent samples where the catchment flume spilled into the concrete channel.

Samples were analyzed for total suspended solids (TSS) following Standard Method \#2540 D (APHA, 1999c). Each 500-mL sample bottle was split into two 250-mL replicates and filtered with Type G4 glass fiber filters (Fisher Scientific) with a pore size of $1.2 \mu \mathrm{m}$ and a diameter of $42.5 \mathrm{~mm}$. The entire volume of each $500-\mathrm{mL}$ sample bottle was filtered along with DI water used to rinse the sample bottle. A separate glass fiber filter and aluminum weigh tray was used for each replicate sample. All glass fiber filters were pre-rinsed with DI water using a Millipore ${ }^{\circledR}$ filter apparatus then dried at $105^{\circ} \mathrm{C}$ and weighed. Each replicate sample was vacuum filtered through the Millipore ${ }^{\circledR}$ filter apparatus, and the filter paper was removed with tweezers and transferred to its designated weigh tray. The weigh trays containing the filters were then transferred to an oven at $105^{\circ} \mathrm{C}$ and dried for one hour. Weigh trays and filters were then transferred to a desiccator to cool for 15 minutes. Filters and weigh trays were weighed a second time. Total suspended solids measurements were determined using the difference between the filter weights and the volume filtered. The TSS of each sample was calculated by the following equation:

$$
\text { TSS }=\frac{\text { Final Weight }- \text { Initial Weight }}{\text { Volume Filtered }}
$$

The sediment removal efficiency was calculated using the following equation:

$$
\text { Removal Efficiency }(\%)=\frac{\text { Influent TSS }- \text { Effluent TSS }}{\text { Influent TSS }} * 100
$$




\subsubsection{DrainPac ${ }^{\circledR}$ Oil and Grease Removal}

Oil and grease removal efficiency was tested at flow rates of 20, 60, 150, and $200 \mathrm{gpm}$. Biodegradable vegetable oil was used to simulate oil and grease deposits found on streets and parking lots. Oil was added to the influent stream using a Cole Palmer ${ }^{\circledR}$ Masterflex ${ }^{\circledR}$ L/STM peristaltic pump. Before each test, the filter was thoroughly cleaned with tap water. For each flow rate, 200 gallons of oil-laden water was allowed to pass through the filter in order to maintain a uniform initial buildup of oil and pond sediment for each test. For the flow rates of 20,60,150, and $200 \mathrm{gpm}$, oil was pumped into the mixing chamber at $2.5,7.6,19.0$, and $25.4 \mathrm{~mL} / \mathrm{sec}$, respectively, to simulate an approximate oil concentration of $30 \mathrm{mg} / \mathrm{L}$ in the water. Influent samples were collected where the water spills into the DrainPac ${ }^{\circledR}$ filter and effluent samples were collected where the catchment flume spills into the concrete channel. Triplicate influent and effluent samples were collected with one person collecting an influent sample and another person collecting the effluent sample at the same time.

Influent and effluent samples were analyzed using a modified Standard Method 5520 B Partition-Gravimetric Method (APHA, 1999a). In this method the oil is extracted into hexane and quantified gravimetrically after all the hexane has been evaporated. Oil extractions were performed in 2-L separatory funnels using a set-up similar to the apparatus described below for bromoform extraction in Figure 9. Hexane extracts were collected in 200-mL TurboVap ${ }^{\circledR}$ vials (Zymark). The Turbovap ${ }^{\circledR}$ vials were thoroughly cleaned with DI water and soap, thoroughly dried, and initially weighed. All water samples were acidified within one hour of collection with 1:1 $\mathrm{HCl}$ to $\mathrm{pH} 2$, which 
generally took $5 \mathrm{~mL}$ of $\mathrm{HCl}$ per liter of water. For oil extraction, a 100-mL water sample was added to a separatory funnel along with $30 \mathrm{~mL}$ of hexane. The separatory funnel was capped and shaken vigorously for approximately one minute, while making sure to release pressure intermittently by opening the stopcock. The separatory funnel was then set back in the ring stand and allowed to settle for 10 minutes. Hexane, being less dense than water settled on top of the aqueous layer. The aqueous layer and a small portion of the organic layer was drained into the original sample container and the rest of the organic layer was drained through approximately $10 \mathrm{~g}$ of anhydrous sodium sulfate in a funnel and collected in a clean Zymark 200-mL TurboVap ${ }^{\circledR}$ vial. The aqueous layer collected in the original sample container was shaken to collect any residual oils in the sample container and added back into the separatory funnel along with an additional 30 $\mathrm{mL}$ of hexane. This procedure was repeated twice more, and after the last extraction step, the final aqueous layer was discarded and $20 \mathrm{~mL}$ of hexane was used to rinse the funnel of anhydrous sodium sulfate to collect any residual oils, and all of the hexane rinsings were collected in the Turbovap ${ }^{\circledR}$ vial. Once extracts for all samples and final rinsings were collected, the Turbovap ${ }^{\circledR}$ vials were transferred to an automated Zymark TurboVap ${ }^{\circledR}$ concentrator (Caliper Lifesciences, Hopkinton, MA), which concentrated the extracts by evaporation with nitrogen, in a $35^{\circ} \mathrm{C}$ water bath. Once the extract finished evaporating, the Turbovap ${ }^{\circledR}$ vials were removed from the water bath, thoroughly dried, and weighed. The difference of the initial and final weights was used to determine the oil concentration in each water sample. 


\subsection{Testing Coliform Removal by a Full-Scale DrainPac ${ }^{\circledR}$ Filter}

Coliform bacteria removal efficiency was tested in the full-scale DrainPac ${ }^{\circledR}$ at flow rates of $20,60,150$, and 200 gpm. Before each test, the filter was thoroughly cleaned with tap water. Samples were collected after 200 gallons of water had passed through the filter in order to maintain a uniform buildup of pond sediment for each test. Preliminary analysis indicated that the pond water contained greater than $2420 \mathrm{CFU} / 100 \mathrm{~mL}$ coliform bacteria which seemed sufficient for coliform removal testing, so no additional bacteria were added. For each flow rate, three influent and three effluent samples were collected in 0.5 L plastic sample bottles. Paired influent and effluent samples were collected simultaneously with one person collecting the influent sample as the water spilled into the DrainPac ${ }^{\circledR}$ Filter and the other person collecting the effluent sample at the bottom of the catchment flume where the water spills into the concrete channel. The samples were diluted 10:1 and analyzed using $\operatorname{Idexx}^{\circledR}$ Colilert $^{\circledR}$ reagents in $\operatorname{Idexx}^{\circledR}$ Quanti-Tray $^{\circledR} / 2000$ trays. The trays were prepared, sealed and incubated using Idexx ${ }^{\circledR}$ equipment, and analyzed in the Cal Poly Microbiology Department. This method tests for viable coliform bacteria using fluorescent indicators. 


\subsection{BIOCIDAL BEAD TESTING}

\subsubsection{Column Apparatus}

A laboratory-scale column apparatus was constructed for testing head loss, bacterial deactivation, and leaching of bromine compounds from the biocidal beads. Two different bead sizes were tested: 0.3 and $0.8 \mathrm{~mm}$ diameter, each with slightly different bromine treatments. The test apparatus consisted of a $17.5-\mathrm{cm}$ long, $1-\mathrm{cm}$ inside diameter glass column. The column was packed with a $1-\mathrm{cm}$ bed depth of beads, corresponding to 0.62 $\mathrm{g}$ of the $0.3 \mathrm{~mm}$ beads or $0.55 \mathrm{~g}$ of the $0.8 \mathrm{~mm}$ beads. The beads were held in place with $0.2 \mathrm{~g}$ of silane-treated glass wool above and below the beads (Figure 7). Pond water was pumped in an up-flow direction with a Masterflex ${ }^{\circledR} \mathrm{L} / \mathrm{S}^{\mathrm{TM}}$ Model $7554-90$ peristaltic pump $\left(\right.$ Cole Parmer $\left.{ }^{\circledR}\right)$. Cole Parmer ${ }^{\circledR} 3$-stop purple-purple PVC Solva ${ }^{\circledR}$ tubing with a 2.06-mm inside diameter was used in the peristaltic pump. The pump tubing was connected to the column using 0.5 -cm inside-diameter Cole Parmer ${ }^{\circledR}$ Tygon ${ }^{\circledR}$ tubing connected with rubber connecters and short glass tubing connectors. Situating the beads at the top of the column and pumping water through the column in an up-flow direction, allowed us to see the direct bacterial-killing and leaching action of the beads, without the complication of additional retention time in the lower empty part of the column. Passing water through the column in an upward direction also alleviated any possible channeling effects. Fresh biocidal beads and glass wool were loaded in the column before each analysis, including for similar analyses at different flow rates. Before each test, 1 L DI water was passed through the column at $0.56 \mathrm{~mL} / \mathrm{sec}$ so that the beads were in the identical wetted condition for each run prior to analysis. 


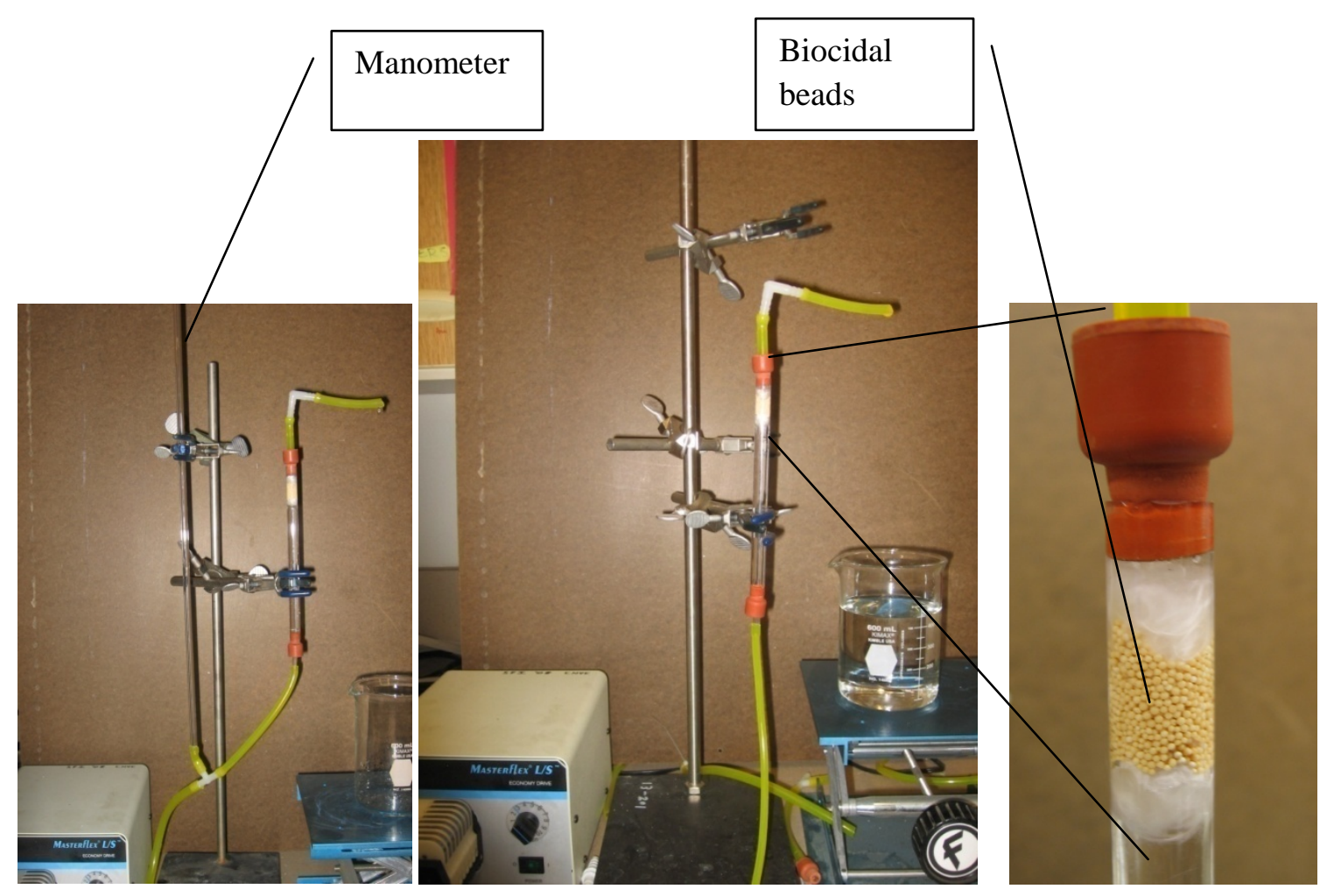

Figure 7. Photograph of column apparatus with manometer in-line for head loss testing (left) and biocidal beads packed in column apparatus (right)

\subsubsection{Column Head Loss Testing}

Head loss was measured through the biocidal beads in the glass laboratory column to estimate the expected head loss in the DrainPac ${ }^{\circledR}$ filter under natural stormwater conditions. This procedure was performed for both the $0.3 \mathrm{~mm}$ beads and the $0.8 \mathrm{~mm}$ beads to determine the head loss differences and feasibility of using the different sized beads in the DrainPac ${ }^{\circledR}$ filter. To determine the head loss of water through the beads alone, head loss was measured while water was pumped through the column under three conditions: empty, with glass wool alone, and with biocidal beads and glass wool. The head loss was measured by connecting a $0.5-\mathrm{cm}$ inside-diameter glass column between 
the peristaltic pump and biocidal bead column to act as a manometer (Figure 7). Head loss measurements were taken under the three conditions at various flow rates by measuring the height of the water in the manometer from the level of the column outlet. For all conditions, DI water was pumped through the column apparatus using a peristaltic pump at $0.28,0.56,0.84,1.12$, and $1.4 \mathrm{ml} / \mathrm{sec}$. These flow rates correspond to superficial velocities of $0.36,0.71,1.07,1.43$, and $1.78 \mathrm{~cm} / \mathrm{sec}$ which correspond to equivalent flow rates of 18, 36, 54, 72, 90 gpm, respectively, through a DrainPac ${ }^{\circledR}$ filter with dimensions of $12 \times 41$ in. (Table 3 ).

\section{Table 3. Laboratory column and $12 \times 41$ in. DrainPac ${ }^{\circledR}$ filter equivalent flow rates}

\begin{tabular}{|c|c|c|}
\hline $\begin{array}{c}\text { Flow Rate } \\
\text { in Column } \\
(\mathrm{mL} / \mathrm{sec})\end{array}$ & $\begin{array}{c}\text { Superficial } \\
\text { Velocity } \\
(\mathrm{cm} / \mathrm{sec})\end{array}$ & $\begin{array}{c}\text { Equivalent } \\
\text { Flow Rate in } \\
\text { DrainPac } \\
\text { Filter }(\mathrm{gpm})\end{array}$ \\
\hline 0.28 & 0.36 & 18 \\
\hline 0.56 & 0.71 & 36 \\
\hline 0.84 & 1.07 & 54 \\
\hline 1.12 & 1.43 & 72 \\
\hline 1.4 & 1.78 & 90 \\
\hline
\end{tabular}

DI water was pumped through the empty column to measure the head loss due to the column apparatus alone at various flow rates. $0.2 \mathrm{~g}$ glass wool was then packed into the column, DI water was pumped through the column at the flow rates of $0.28,0.56,0.84$, 1.12 , and $1.4 \mathrm{ml} / \mathrm{sec}$, and head-loss measurements were taken. Then, the glass wool was removed and $0.62 \mathrm{~g}$ of $0.3 \mathrm{~mm}$ beads were placed in the column and held in place with $0.2 \mathrm{~g}$ glass wool. DI water was pumped through the column at the same flow rates and head loss measurements were taken. For testing the $0.8 \mathrm{~mm}$ biocidal beads, the same procedure was followed using approximately $0.55 \mathrm{~g}$ of the $0.8 \mathrm{~mm}$ beads, equivalent to a 1-cm height of beads in the column. 


\subsubsection{Measurement of Leaching}

Bromine, bromoform, and bromide leaching was tested by sampling pond water that had been passed through the laboratory column containing a 1-cm deep bed of biocidal beads at three different flow rates. The biocidal beads were suspended at the top of the column in between approximately $0.2 \mathrm{~g}$ of glass wool. Both $0.3 \mathrm{~mm}$ (Lot \# 06-HPBR-0507) and $0.8 \mathrm{~mm}$ beads (Lot \# 08-HPBR-0519) were used for all leaching tests. Pond water was passed through the column in an up-flow direction at $0.28,0.56$, and $0.84 \mathrm{~mL} / \mathrm{sec}$,

equivalent to 18,36 , and 54 gpm flow rates in a Drainpac ${ }^{\circledR}$ filter measuring 12 x 41 in. (Table 3). At each of the three flow rates, $1 \mathrm{~L}$ of DI water was passed through the column of fresh beads at $0.56 \mathrm{~mL} / \mathrm{sec}$ prior to introducing pond water to the column so the beads would be at the same condition for tests at all three flow rates.

\subsubsection{Bromine Sample Collection and Analysis}

For bromine analysis, samples were collected directly in $25-\mathrm{mL}$ volumetric flasks and analyzed after collection. Approximately $200-\mathrm{mL}$ of pond water passed through the column in between the collection of each sample.

Bromine was analyzed using a $\mathrm{Hach}^{\circledR}$ bromine test kit utilizing a colorimetric N, Ndiethyl-p-phenylenediamine (DPD) Total Chlorine Reagent. The DPD Total Chlorine Reagent acts the same way with bromine as with chlorine, only with a different colorimetric scale. Leachate samples from $0.3 \mathrm{~mm}$ and $0.8 \mathrm{~mm}$ biocidal beads and 0.8 $\mathrm{mm}$ unactivated control beads were analyzed by immediately adding DPD reagent to 
each 25-mL sample. The flask was capped and gently shaken for three minutes and transferred to the $\operatorname{Hach}^{\circledR}$ bromine test kit for a color comparison of the sample to the scale on the side of the test cube. Samples were read by fellow graduate students, unaware of the experiment, so that the color interpolation would not be biased.

To test the bromine method for these analyses, a dilution experiment was conducted to determine how the DPD reagent reacts to diluted bromine samples. A 25-mL DI flush water effluent sample collected from a 1-cm depth of $0.3 \mathrm{~mm}$ beads at a flow rate of 0.56 $\mathrm{mL} / \mathrm{sec}$ was analyzed for bromine after the addition of the DPD reagent. The observed bromine concentration of the undiluted $25-\mathrm{mL}$ sample was $1.4 \mathrm{mg} / \mathrm{L}$. Then, separate 10 , 5, and 3-mL DI flush water effluent samples were collected, diluted with 15, 20, and 22 $\mathrm{mL}$ fresh DI water, respectively, and analyzed for bromine. The solution containing only $3 \mathrm{~mL}$ of effluent sample produced a very subtle pink color in the volumetric flask, but no color was observed once it was transferred to the $\mathrm{Hach}^{\circledR}$ kit containing the colorimetric scale. The DPD reagent produced a linear reaction to diluted bromine samples (Figure 8). The lower detection limit of the DPD reagent for bromine was estimated from this analysis to be $0.05 \mathrm{mg} / \mathrm{L}$. 


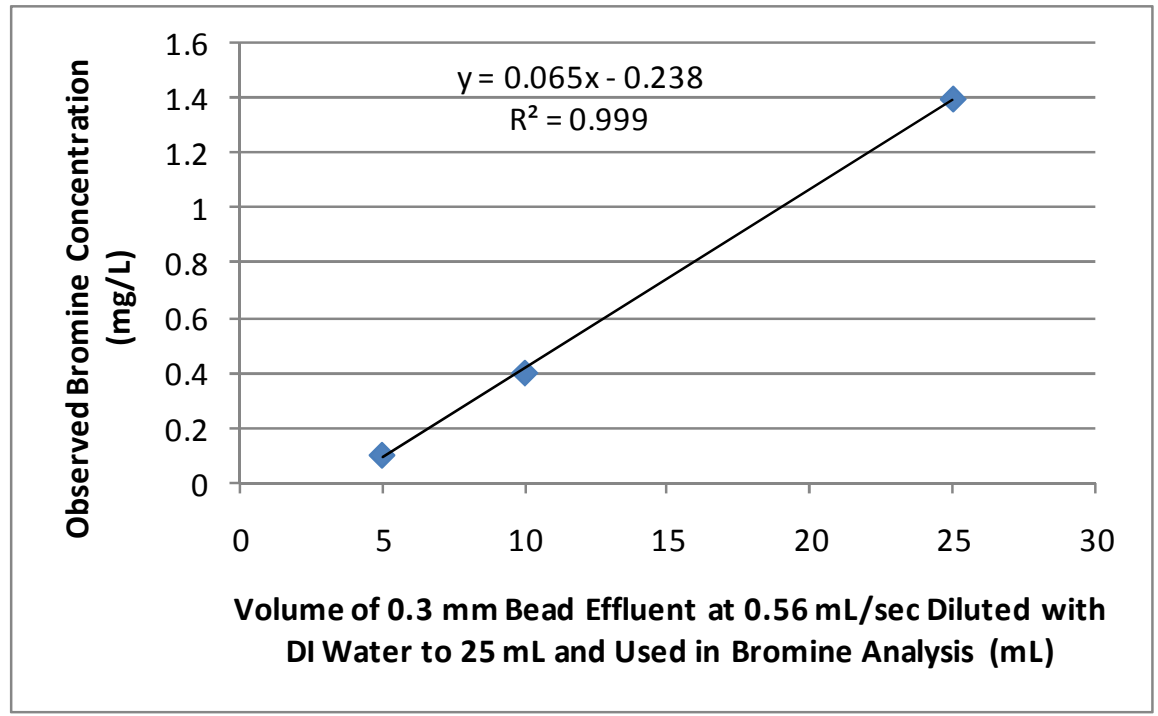

Figure 8. Reaction of DPD reagent to diluted bromine samples

\subsubsection{Bromoform Sample Collection and Analysis}

Effluent water samples for bromoform analysis were collected in a graduated cylinder. Approximately $100 \mathrm{~mL}$ of pond water was allowed to pass through the column between the collection of each pond water effluent sample. Bromoform samples were quenched with $0.04 \mathrm{~N}$ sodium thiosulfate reducing bromine into bromide, thus deactivating the disinfecting properties of the bromine. This quenching is also expected to stop additional bromoform from being formed. Four different sample quenching scenarios were used: one sample was taken without quenching with sodium thiosulfate, and other samples were quenched immediately after passing through the column (samples collected in graduated cylinder containing sodium thiosulfate), once the entire $147 \mathrm{~mL}$ sample had been taken, and after 10 minutes of an entire sample being taken. Duplicate samples for each of the four quenching scenarios were taken at all three flow rates. In addition, DI 
flush water samples from 0.3 and $0.8 \mathrm{~mm}$ beads were quenched after sample collection and analyzed for bromoform.

A modified Standard Method 6232 B (APHA, 1999b) was used to extract bromoform contained in the water samples into methylene chloride $(\mathrm{MeCl})$. Water samples were placed in the refrigerator and extracted the same day that they were collected. All glassware was washed prior to extraction with Alconox soap and DI water and then rinsed twice with $\mathrm{MeCl}$. All extractions were performed in a fume hood using ring stands to hold up 1-L separatory funnels and Pyrex $^{\circledR}$ funnels as shown in Figure 12. The Pyrex ${ }^{\circledR}$ funnels were filled with anhydrous sodium sulfate and held with ring stands below the separatory funnels. The anhydrous sodium sulfate was used to remove any water that may be in the $\mathrm{MeCl}$ phase. Glass wool was used to plug the bottom of the funnel so that anhydrous sodium sulfate wouldn't come out as the extract was trickled through it. Zymark 200-mL TurboVap ${ }^{\circledR}$ vials were clamped below the funnels to collect the extract. 


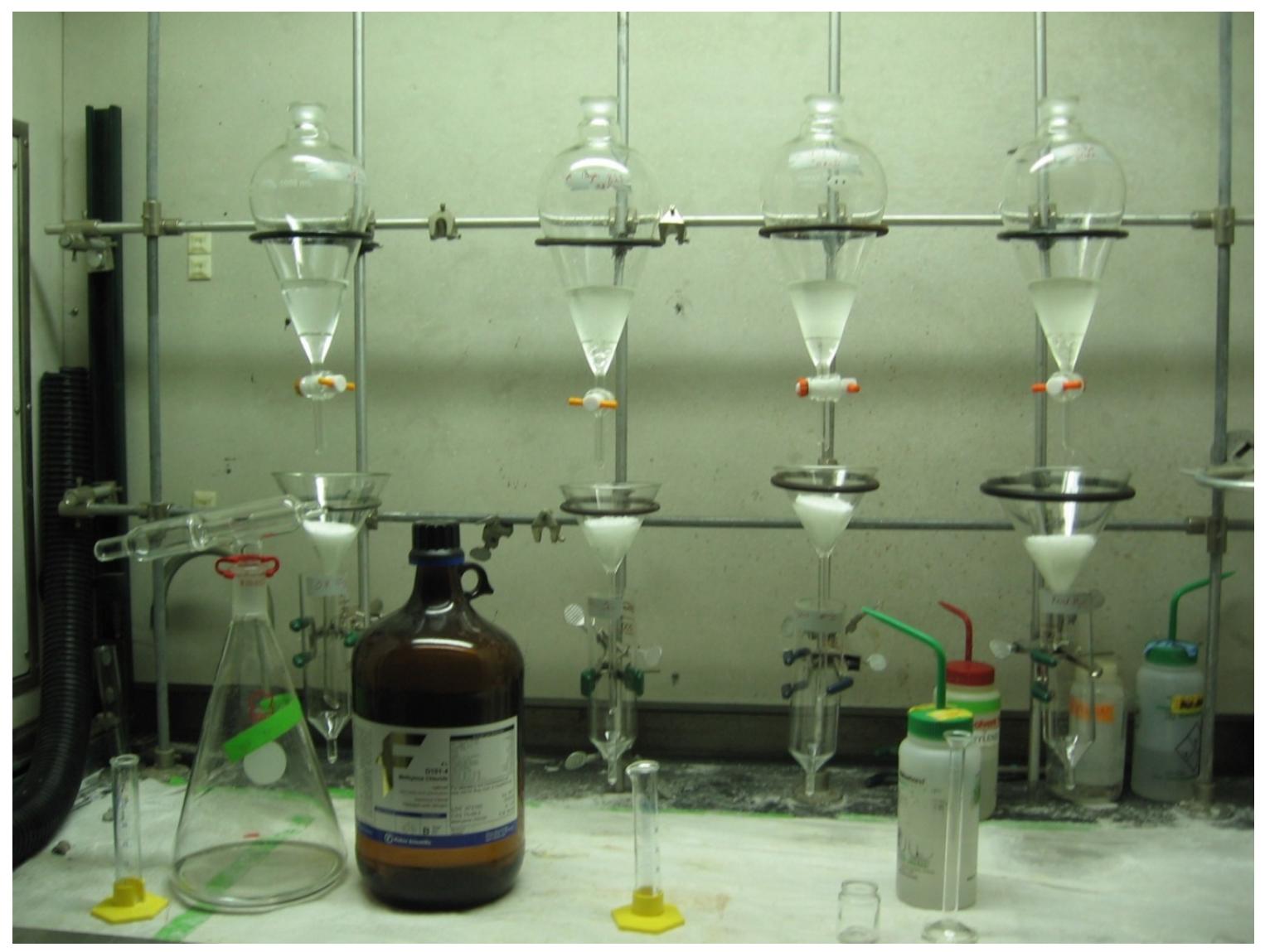

Figure 9. Photograph of bromoform extraction set-up

Bromoform water samples in 100-mL aliquots were pipetted into the 1-L separatory funnels using a $100-\mathrm{mL}$ pipette. $15 \mathrm{~mL}$ of $\mathrm{MeCl}$ was measured out using a 25-mL graduated cylinder and poured into each separatory funnel. Each separatory funnel was then capped and vigorously shaken for approximately one minute, while being careful to release built up pressure by tilting the separatory funnel back and opening the stopcock. The separatory funnel was then set back in the ring stand, uncapped, and let to sit for 10 minutes. Since the $\mathrm{MeCl}$ with dissolved bromoform phase is denser than water, it settled to the bottom below the aqueous layer. The $\mathrm{MeCl}$ extract layer was then slowly drained through the funnel filled with anhydrous sodium sulfate and into the TurboVap ${ }^{\circledR}$ vial. An 
additional $15 \mathrm{~mL}$ of $\mathrm{MeCl}$ was then added to the separatory funnel, and the extraction was repeated twice more. After the third cycle, the funnel filled with anhydrous sodium sulfate was thoroughly rinsed with approximately $30 \mathrm{~mL}$ of $\mathrm{MeCl}$ to collect any residual bromoform that may be present in the anhydrous sodium sulfate or glass wool.

Once the extract and $\mathrm{MeCl}$ final rinse were collected, the TurboVap ${ }^{\circledR}$ vials were placed in an automated Zymark TurboVap ${ }^{\circledR}$ concentrator (Caliper Lifesciences, Hopkinton, MA). This unit concentrated the extract by evaporation with nitrogen gas while the TurboVap ${ }^{\circledR}$ beakers were set in a $35^{\circ} \mathrm{C}$ water bath. The Zymark TurboVap ${ }^{\circledR}$ unit was set at an end point sensor which concentrated the extract to a final volume of $0.75 \mathrm{~mL}$. After evaporation, the TurboVap ${ }^{\circledR}$ vials were transferred back to the fume hood and set in a metal holder. The $0.75 \mathrm{~mL}$ of concentrated extract was transferred to a $10-\mathrm{mL}$ graduated cylinder with a 2-mL glass Pasteur pipette. The vial was then rinsed with approximately $1 \mathrm{~mL}$ of $\mathrm{MeCl}$ and the rinsed $\mathrm{MeCl}$ was then transferred to the 10 -mL graduated cylinder. This was repeated until the final volume in the graduated cylinder reached approximately $5 \mathrm{~mL}$. The exact final volume in the graduated cylinder was recorded and later used to calculate the actual concentration of bromoform in the water samples. The extract was then transferred into two 2-mL crimp-top vials which were then capped and stored in a freezer for future analysis by gas chromatography.

All extracted samples were analyzed in an Agilent Technologies 6890N Gas Chromatograph (GC) and an Agilent Technologies 5975 B inert mass spectrometer (MS) with an Agilent Technologies 7683 B Series injector. An Agilent Technologies HP-5ms capillary column (part number 19091S-433) containing a 5\% phenyl and 95\% dimethylpolysiloxane wall coating with nominal diameter of $0.25 \mathrm{~mm}$, nominal length of 
$30 \mathrm{~m}$, and nominal film thickness of $0.25 \mu \mathrm{m}$ was used in the GC (Table 4). Operating conditions used in the GC are displayed in Table 4. The GC temperature program used in the bromoform analysis is displayed in Table 5.

Table 4. GC operating conditions

\begin{tabular}{|l|l||l|l|}
\hline \multicolumn{3}{|c|}{ Front Inlet } \\
\hline Mode: & Splitless & Purge Flow: & $50 \mathrm{~mL} / \mathrm{min}$ \\
\hline Initial Temp: & $200^{\circ} \mathrm{C}$ & Total Flow: & $54.4 \mathrm{~mL} / \mathrm{min}$ \\
\hline Pressure: & $11.55 \mathrm{psi}$ & Gas Type: & Helium \\
\hline \multicolumn{3}{|c|}{ Column } \\
\hline Model: & Agilent 19091S-433 & Nominal Film Thickness: & $0.25 \mu \mathrm{m}$ \\
\hline Max Temp: & $325^{\circ} \mathrm{C}$ & Initial Flow: & $1.5 \mathrm{~mL} / \mathrm{min}$ \\
\hline Nominal Length: & $30.0 \mathrm{~m}$ & Average Velocity: & $44 \mathrm{~cm} / \mathrm{sec}$ \\
\hline Nominal Diameter: & $250 \mu \mathrm{m}$ & Nominal Init. Pressure: & $11.56 \mathrm{psi}$ \\
\hline Mode: & Constant Flow & & \\
\hline
\end{tabular}

Table 5. GC oven temperature program

\begin{tabular}{|c|c|c|}
\hline \multicolumn{3}{|c|}{ Initial Temperature: $35^{\circ} \mathrm{C}$} \\
\hline \multicolumn{3}{|c|}{ Final Temperature: $200^{\circ} \mathrm{C}$} \\
\hline $\begin{array}{c}\text { Rate } \\
\left({ }^{\circ} \mathrm{C} / \mathrm{min}\right)\end{array}$ & $\begin{array}{c}\text { Final } \\
\text { Temperature }\left({ }^{\circ} \mathrm{C}\right)\end{array}$ & $\begin{array}{c}\text { Final Time } \\
(\mathrm{min})\end{array}$ \\
\hline 0 & 35 & 5 \\
\hline 10 & 70 & 8.5 \\
\hline 20 & 200 & 15 \\
\hline
\end{tabular}

Bromoform standards were prepared gravimetrically at concentrations of 10, 50, 100, 250, and $350 \mathrm{mg} / \mathrm{L}$ in $\mathrm{MeCl}$. These standards were run in the $\mathrm{GC}$ and the resulting peak curves were used to make a standard curve (Figure 10). Additional bromoform standards were prepared for analysis of the dry storage longevity beads and the standard curve is displayed in the Appendix (Figure A-4). 


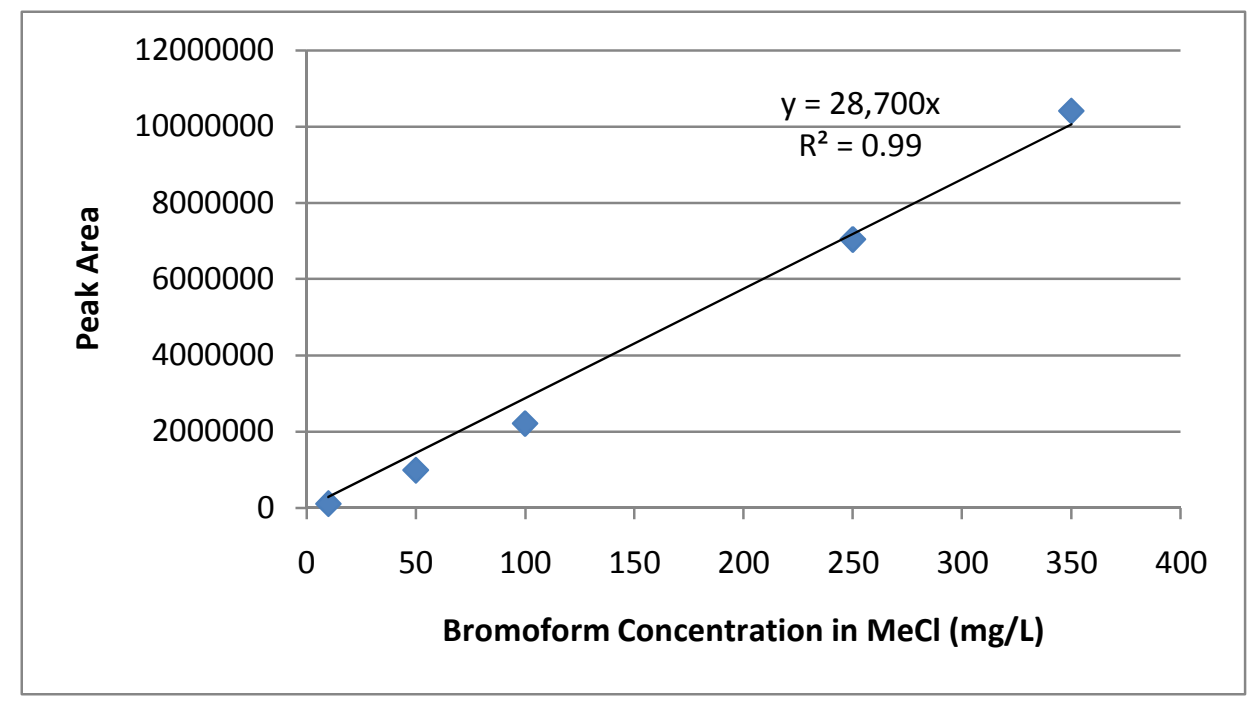

Figure 10. Bromoform standard curve

A $\mathrm{MeCl}$ blank and at least one bromoform standard were run with all sets of samples to detect any potential operating problems with the GC. The average peak area produced by $10 \mathrm{MeCl}$ blanks was 4940. The highest $\mathrm{MeCl}$ blank out of the 10 blanks produced a peak area of 9523, which corresponds to $0.33 \mathrm{mg} / \mathrm{L}$ in $\mathrm{MeCl}$ (using the bromoform standard curve in Figure A-4) or about $0.025 \mathrm{mg} / \mathrm{L}$ bromoform concentration in water. The $\mathrm{MeCl}$ blank that produced the highest peak area was taken as a conservative lower detection limit for bromoform. For quality control, a blind duplicate sample of the pond water effluent from the $0.8 \mathrm{~mm}$ beads at a $0.28 \mathrm{~mL} / \mathrm{sec}$ flow rate was analyzed for bromoform by Creek Environmental Laboratories, Inc. in San Luis Obispo. 


\subsubsection{Bromide Sample Collection and Analysis}

Bromide was measured in DI flush water and pond water passed through $0.3 \mathrm{~mm}$ beads at a flow rate of $0.56 \mathrm{~mL} / \mathrm{sec}$ and through $0.8 \mathrm{~mm}$ beads at flow rates of $0.56 \mathrm{~mL} / \mathrm{sec}$ and $0.28 \mathrm{~mL} / \mathrm{sec}$. Effluent samples were collected in $40-\mathrm{mL}$ volatile organic analysis (VOA) vials. Approximately $100 \mathrm{~mL}$ of pond water was allowed to pass through the column between the collection of each bromide sample.

Bromide effluent concentrations were analyzed using a Dionex ${ }^{\circledR}$ DX-120 ion chromatogram (IC) with an IonPac ${ }^{\circledR}$ AS22 4x250-mm column (Figure 14). Bromide effluent samples were filtered within one hour of sample collection with $0.22-\mu \mathrm{m}$ Millipore Express PLUS ${ }^{\circledR}$ membrane filters using a HDPE plunger syringe, placed in 5$m L$ Dionex ${ }^{\circledR}$ PolyVials, and capped with Dione ${ }^{\circledR} 20-\mu \mathrm{m}$ filter caps before analysis. Samples were placed in the freezer for no more than one week before analysis.

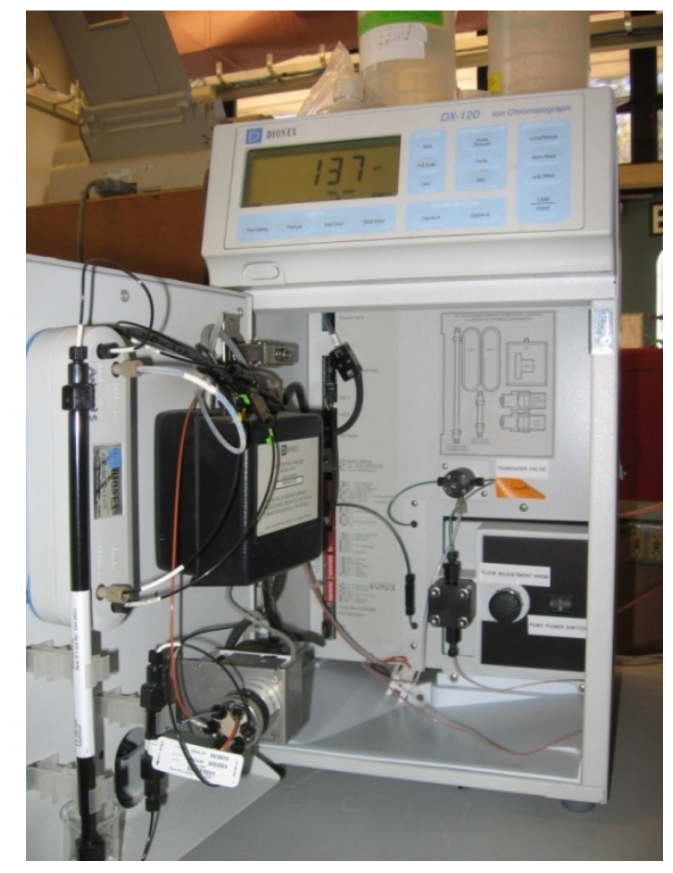

Figure 11. Dionex ${ }^{\circledR}$ DX-120 ion chromatograph 
Bromide standards were prepared by diluting Dionex ${ }^{\circledR}$ 7-Anion Standard with DI water to bromide concentrations of $0.25,0.5,0.75,1$, and $2 \mathrm{mg} / \mathrm{L}$. New standards were prepared for each set of samples run through the IC. Data for preparing the standard curve for the $0.3 \mathrm{~mm}$ bead run are displayed in Table 6 and the resulting calibration curve is in Figure 12. Other bromide standard curves can be found in Appendix A. The standard curves were created by comparing the peak areas of the bromide peaks to the known concentrations of each standard. Duplicate standards were made and the average area was used for each point on the standard curve. Sample concentrations were then calculated using the peak area of each samples' bromide peak in the bromide standard curve formula created for that specific sample run.

Table 6. Bromide standard data for $0.3 \mathrm{~mm}$ bead run

\begin{tabular}{|c|c|c|c|}
\hline $\begin{array}{c}\text { Standard } \\
\text { Concentration } \\
(\mathrm{mg} / \mathrm{L})\end{array}$ & $\begin{array}{l}\text { Peak } \\
\text { Area }\end{array}$ & $\begin{array}{l}\text { Retention } \\
\text { Time }\end{array}$ & $\begin{array}{c}\text { Average } \\
\text { Area }\end{array}$ \\
\hline \multirow{2}{*}{0.25} & 0.023 & 7.30 & \multirow{2}{*}{0.022} \\
\hline & 0.021 & 7.20 & \\
\hline \multirow{2}{*}{0.5} & 0.045 & 7.20 & \multirow{2}{*}{0.048} \\
\hline & 0.051 & 7.18 & \\
\hline \multirow{2}{*}{0.75} & 0.067 & 7.18 & \multirow{2}{*}{0.070} \\
\hline & 0.073 & 7.20 & \\
\hline \multirow{2}{*}{1} & 0.084 & 7.17 & \multirow{2}{*}{0.091} \\
\hline & 0.097 & 7.20 & \\
\hline
\end{tabular}




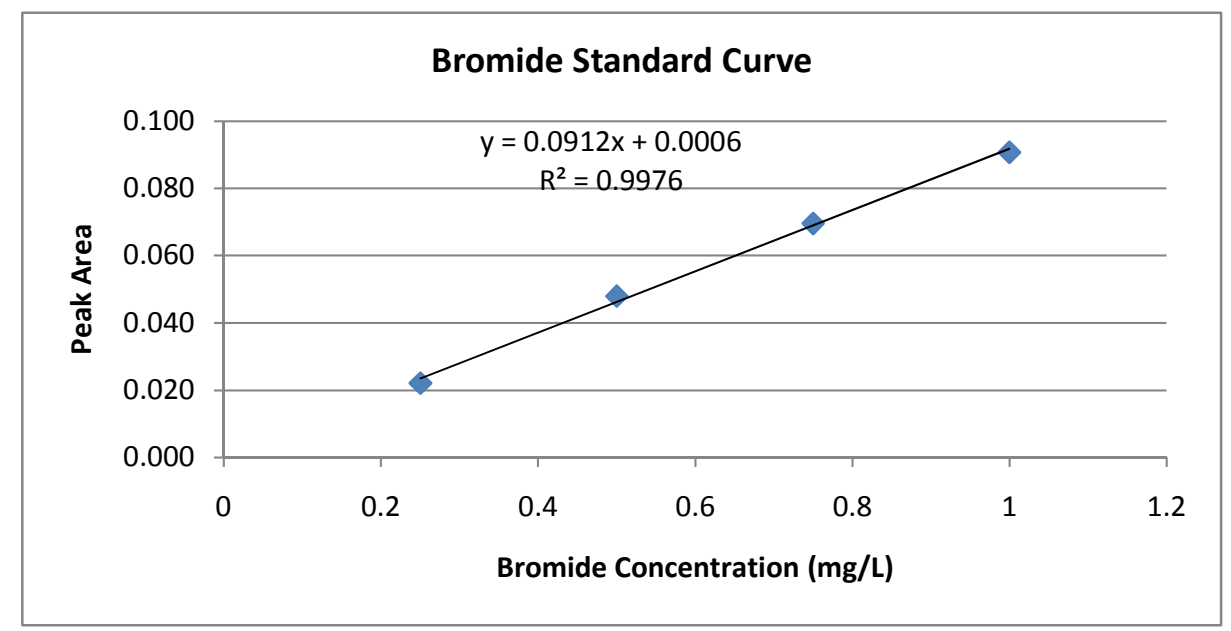

Figure 12. Bromide standard curve for $0.3 \mathrm{~mm}$ bead test

\subsubsection{Measurement of Bromine Leaching During Longevity Testing}

\section{Simulated Use Cycles}

The longevity of the $0.3 \mathrm{~mm}$ biocidal beads was tested by inducing five simulated use cycles in the laboratory column consisting of five consecutive wet and dry cycles to simulate realistic stormwater conditions in actual storm drains. Only the $0.3 \mathrm{~mm}$ biocidal beads were tested for their longevity because the $0.8 \mathrm{~mm}$ beads were not available at the time the experiment began. Each wet cycle consisted of pumping pond water through the column packed with a $1-\mathrm{cm}$ bed depth of $0.3-\mathrm{mm}$ biocidal beads for one hour at a flow rate of $0.56 \mathrm{~mL} / \mathrm{sec}$, corresponding to a superficial water velocity of $0.71 \mathrm{~cm} / \mathrm{sec}$. Each wet cycle involved approximately $2 \mathrm{~L}$ of pond water passing through the beads. To avoid accumulation of organic material from the pond water clogging the column, a separate 1.5-inch long glass column was packed with glass wool and attached before the 
bead column to filter the water prior to entering the bead column (Figure 13). The glass wool in the filter column was replaced before each wet cycle to avoid clogging.

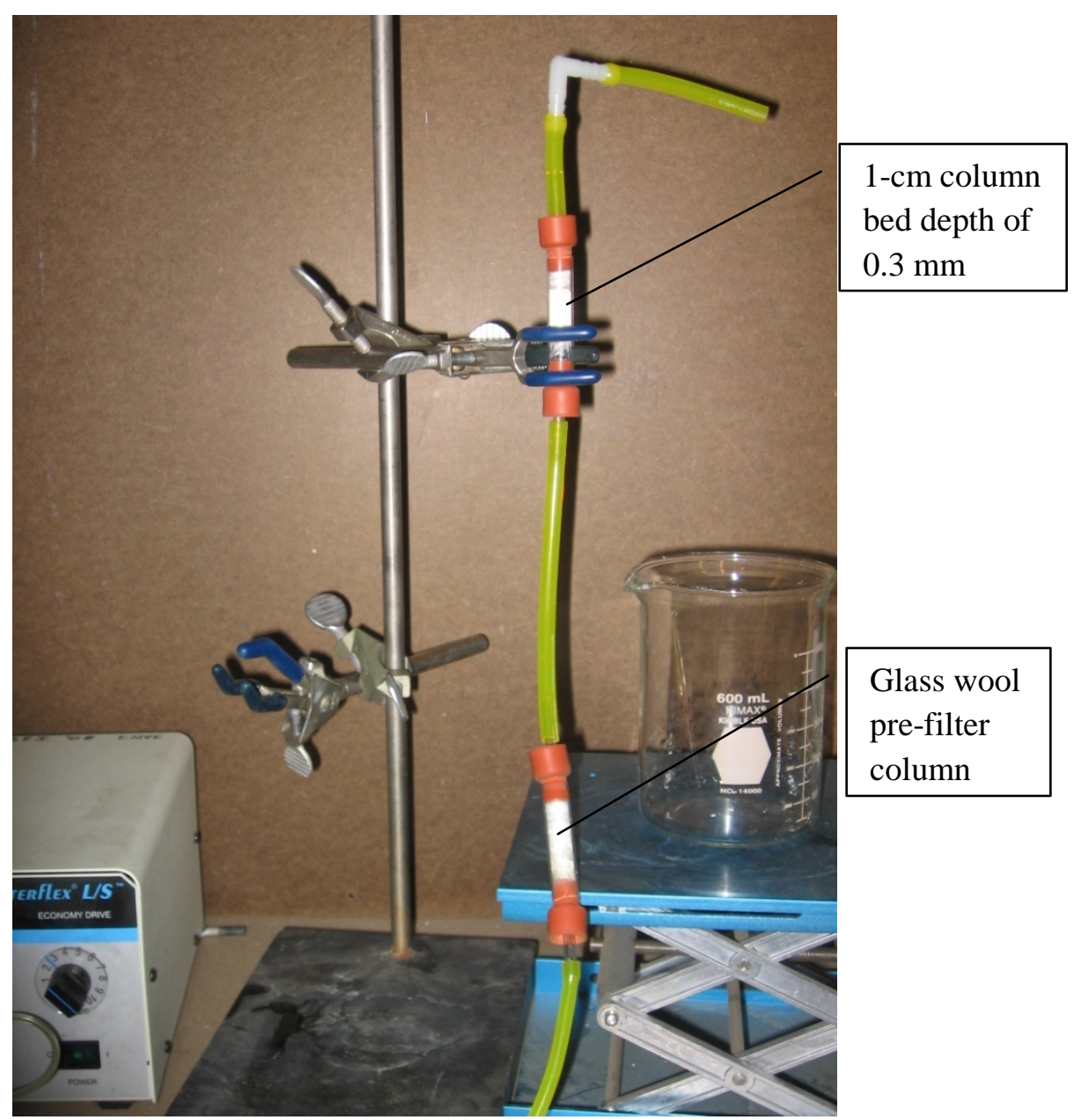

Figure 13. Simulated use cycle test apparatus with separate glass wool filter column

After each wet cycle, the bead column was attached to a Profile ${ }^{\circledR} 2900$ aquarium air pump and air was pumped through the column of beads overnight. At the end of each dry cycle, the biocidal beads were often floating around, suspended by the air being pumped through the column, suggesting that the beads were dry. The biocidal beads were initially flushed by pumping 1 liter of DI water through the column at $0.56 \mathrm{~mL} / \mathrm{sec}$ prior to the 
first wet cycle. On the fifth day, directly after the fifth wet cycle, the pond water effluent was sampled for bromine, bromide, and bromoform. Coliform bacteria removal was determined separately in a companion study.

Bromine was tested first since it requires immediate analysis. Three separate bromine samples were tested immediately after collecting each sample in a $25-\mathrm{mL}$ volumetric flask. Bromine was analyzed using a $\mathrm{Hach}^{\circledR}$ Bromine Test Cube and DPD Total Chlorine Reagent as previously described. Approximately $250 \mathrm{~mL}$ of pond water passed through the beads between the collection of each bromine sample.

Bromoform samples were collected and quenched immediately after collection with sodium thiosulfate after and placed in the refrigerator. An approximately $147-\mathrm{mL}$ effluent sample was collected in a 200-mL graduated cylinder and added to $73 \mathrm{~mL}$ sodium thiosulfate in a $250-\mathrm{mL}$ beaker. Two $100-\mathrm{mL}$ aliquots of the $220-\mathrm{mL}$ total sample were extracted into $\mathrm{MeCl}$ and analyzed with a GC/MS as described above. Approximately $50 \mathrm{ml}$ of pond water passed through the beads after the first $147-\mathrm{mL}$ sample was taken and $300 \mathrm{~mL}$ pond water passed through the beads after the collection of the last bromoform sample. Bromoform samples were then extracted into $\mathrm{MeCl}$ and the extracts were placed in two 2-mL crimp-top vials, capped, and placed in the freezer for future analysis with a GC/MS.

Three bromide effluent samples were then collected in 40-mL VOA vials. Approximately $50 \mathrm{ml}$ of pond water was allowed to pass through the beads between the collection of each sample. Bromide samples were filtered with 25-mm diameter, 0.22$\mu \mathrm{m}$ Millipore Express PLUS ${ }^{\circledR}$ membrane filters and placed in 5-mL Dionex ${ }^{\circledR}$ PolyVials 
and capped with Dionex ${ }^{\circledR}$ PolyVial $20-\mu \mathrm{m}$ filter caps and placed in the freezer until IC analysis as described above.

\section{Dry Storage}

Leachate from $0.3 \mathrm{~mm}$ biocidal beads was analyzed for bromine, bromoform, and bromide after fresh beads were initially wet and then stored in a laboratory fume hood, open to ambient air for over five months (162 days). Prior to dry storage, fresh beads were wetted by passing one liter of DI water through the beads at $0.56 \mathrm{~mL} / \mathrm{sec}$. The beads were then removed from the column and set in a beaker in the fume hood for 162

days. After dry storage, $0.62 \mathrm{~g}$ of the beads were set in the laboratory column and one liter of DI water was pumped through the beads at $0.56 \mathrm{ml} / \mathrm{sec}$, followed by pond water at the same flow rate. The pond water leachate was sampled and tested for bromine, bromoform, and bromide as described above. 


\title{
CHAPTER 4: RESULTS AND DISCUSSION
}

\author{
4.1 DrainPaC ${ }^{\circledR}$ FILTER Results
}

\subsubsection{DrainPac ${ }^{\circledR}$ Filter Head Loss Results}

\section{Head Loss of Clean DrainPac ${ }^{\circledR}$ Filter}

The head loss in the clean DrainPac ${ }^{\circledR}$ filter varied from $0.5 \mathrm{~cm}$ at $20 \mathrm{gpm}$ to $9.1 \mathrm{~cm}$ at 200 gpm (Table 7). Head loss in the full-scale DrainPac ${ }^{\circledR}$ filter increased linearly with increasing flow rate (Figure 14, $\mathrm{r}^{2}=0.955$ ). At all of these flow rates, the water did not overflow the filter (bypass the filter fabric and pass through the mesh screen). At the end of the $200 \mathrm{gpm}$ head loss measurement there was a very thin film of solids that accumulated on the bottom of the filter from solids in the pond water.

Table 7. Clean filter head loss at various flow rates

\begin{tabular}{|c|c|}
\hline Flow (GPM) & Head Loss $(\mathrm{cm})$ \\
\hline 20 & 0.5 \\
\hline 50 & 2.8 \\
\hline 80 & 3.8 \\
\hline 115 & 4.9 \\
\hline 150 & 5.5 \\
\hline 175 & 8.5 \\
\hline 200 & 9.1 \\
\hline
\end{tabular}




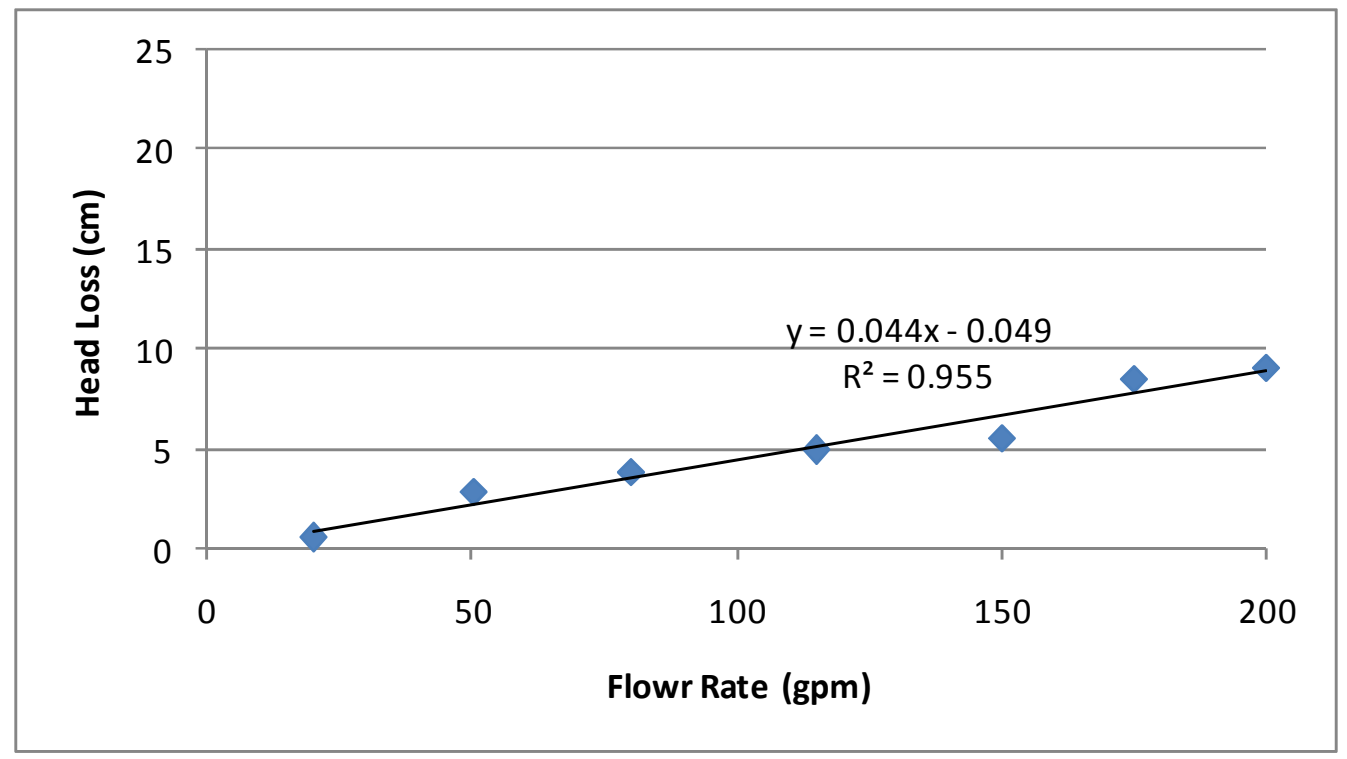

Figure 14. Clean filter head loss at various flow rates

\section{DrainPac $^{\circledR}$ Filter Loading Test at 200 GPM}

The DrainPac ${ }^{\circledR}$ filter was loaded at $200 \mathrm{gpm}$ at a solids concentration of $80-100 \mathrm{mg} / \mathrm{L}$.

The total amount of solids, including the solids present in the pond water, that caused the filter to overflow (21.5 $\mathrm{cm}$ head loss) at $200 \mathrm{gpm}$ was 625 grams (Table 8$)$. The approximate loading rate was thus $40 \mathrm{~g} / \mathrm{min}$. Head loss increased linearly as solids were added to the filter, until water began to flow over the top of the filter fabric at full loading (Figure 15). 
Table 8. Head loss of DrainPac ${ }^{\circledR}$ filter at $200 \mathrm{gpm}$ during solids loading (40 g/min)

\begin{tabular}{|c|c|}
\hline $\begin{array}{c}\text { Head Loss }(\mathrm{cm}) \\
\text { at } 200 \mathrm{gpm}\end{array}$ & Total Filter Loading $(\mathrm{g})$ \\
\hline 8 & 147 \\
\hline 11.5 & 269 \\
\hline 13.8 & 378 \\
\hline 16.7 & 511 \\
\hline 21.5 & 625 \\
\hline
\end{tabular}

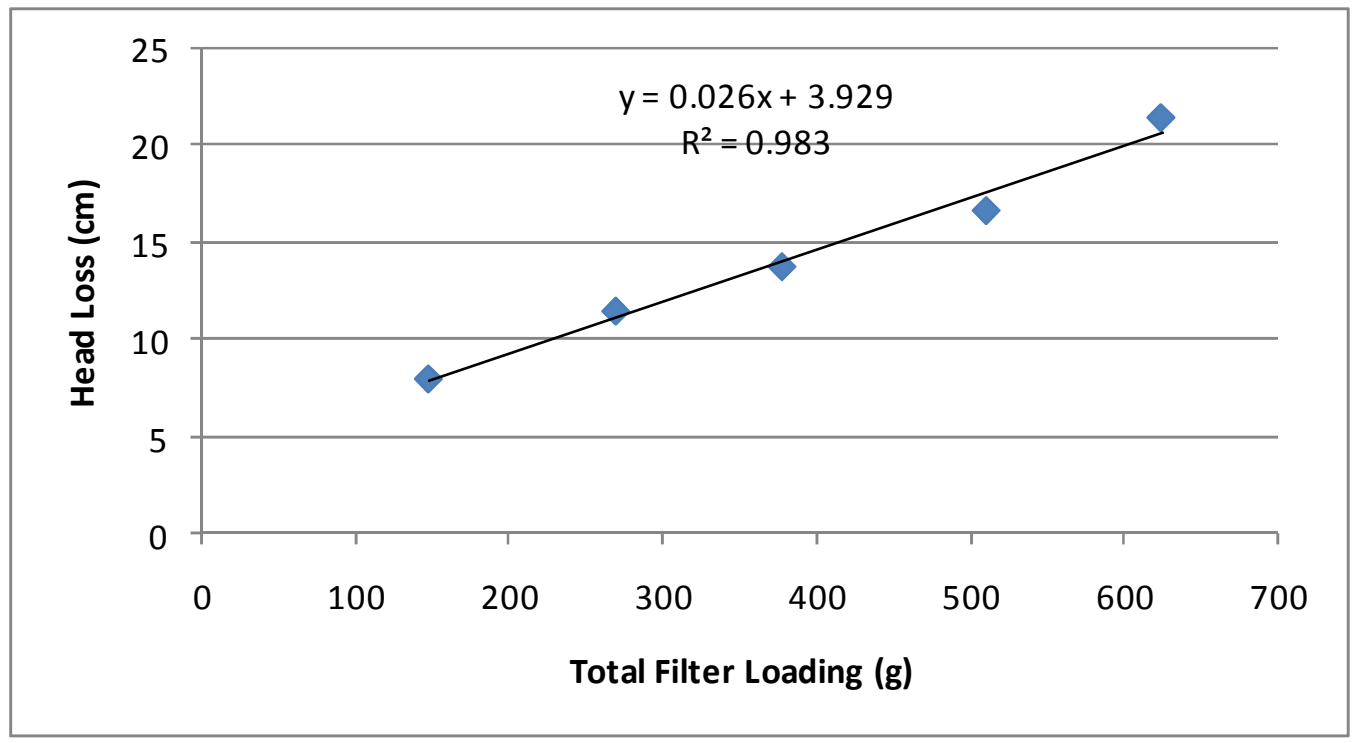

Figure 15. Head loss of DrainPac ${ }^{\circledR}$ filter at $200 \mathrm{gpm}$ during solids loading (40 g/min)

\section{Loaded DrainPac ${ }^{\circledR}$ Filter Head Loss}

This test evaluated the head loss in the DrainPac ${ }^{\circledR}$ filter at various flow rates after the filter was completely loaded by the previous test above. The filter was considered fully loaded once the addition of solids into flowing water at 200 gpm caused water to overflow through the mesh screen. The filter was completely loaded at 200 gpm once a total of $625 \mathrm{~g}$ of solids (including solids present in the pond water) was added to the filter 
as described above. The head loss in the loaded filter was measured at flow rates of 20 and $80 \mathrm{gpm}$. At higher flow rates the filter began to overflow. At $80 \mathrm{gpm}$, the loaded filter had a head loss of $17.5 \mathrm{~cm}$ (Figure 16). The DrainPac ${ }^{\circledR}$ filter was first loaded at 200 gpm, similar to high sediment loading in a catch basin filter during a large storm event, and then later failed to filter pond water at flow rates higher than $80 \mathrm{gpm}$. This proves how vital routine maintenance of the DrainPac ${ }^{\circledR}$ filter is to its performance after large storm events.

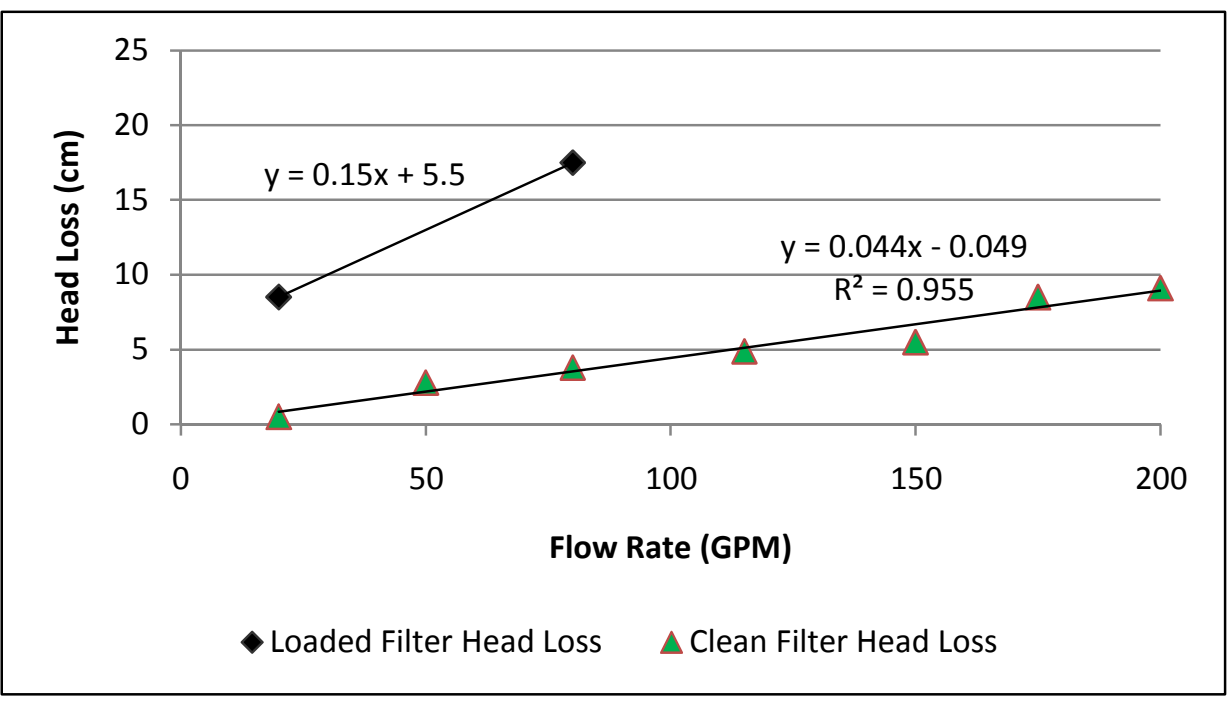

Figure 16. Head loss through DrainPac ${ }^{\circledR}$ filter loaded with $625 \mathrm{~g}$ solids compared to clean filter head loss

\subsubsection{Sediment Removal by the Full-Scale DrainPac ${ }^{\circledR}$ Filter}

Average influent and effluent TSS concentrations are displayed in Table 9 for each flow rate. Average sediment removal efficiencies ranged from $83 \%$ to $91 \%$ (Table 10). The sediment removal efficiency decreased slightly with increasing flow rate, however this trend is not statistically significant based on the error bars in Figure 17. Variation in TSS 
concentrations among influent samples in Table 9 could be partly due to sand settling along the sides of the test flume. Although sediment removal efficiencies were variable, the DrainPac ${ }^{\circledR}$ filter performed relatively well at higher flow rates, with sediment removal efficiencies ranging from $72-93 \%$ at 200 gpm (Table 10).

Table 9. Influent and effluent TSS measurements for DrainPac ${ }^{\circledR}$ filter testing at various flow rates

\begin{tabular}{|c|c|c|c|c|c|}
\hline \multirow{2}{*}{ Sample } & \multirow{2}{*}{ Replicate } & \multicolumn{4}{|c|}{ TSS (mg/L) } \\
\cline { 3 - 6 } & & $20 \mathrm{gpm}$ & $60 \mathrm{gpm}$ & $150 \mathrm{gpm}$ & $200 \mathrm{gpm}$ \\
\hline \multirow{3}{*}{ Influent } & 1 & 62.6 & 23.0 & 62.8 & 35.6 \\
\cline { 2 - 6 } & 2 & 54.6 & 37.6 & 130.5 & 39.8 \\
\cline { 2 - 6 } & 3 & 63.3 & 51.8 & 110.3 & 26.2 \\
\hline \multirow{3}{*}{ Effluent } & 1 & 5.7 & 4.7 & 18.6 & 2.6 \\
\cline { 2 - 6 } & 2 & 4.2 & 1.3 & 12.8 & 5.9 \\
\cline { 2 - 6 } & 3 & 6.5 & 4.3 & 13.1 & 7.3 \\
\hline
\end{tabular}

Table 10. DrainPac ${ }^{\circledR}$ filter sediment removal efficiency

\begin{tabular}{|c|c|c|c|c|}
\hline \multirow{2}{*}{ Sample } & \multicolumn{4}{|c|}{ Sediment Removal Efficiency (\%) } \\
\cline { 2 - 5 } & $20 \mathrm{gpm}$ & $60 \mathrm{gpm}$ & $150 \mathrm{gpm}$ & $200 \mathrm{gpm}$ \\
\hline 1 & 90.8 & 79.4 & 70.4 & 92.7 \\
\hline 2 & 92.2 & 96.5 & 90.2 & 85.3 \\
\hline 3 & 89.7 & 91.6 & 88.1 & 72.0 \\
\hline Average & 90.9 & 89.2 & 82.9 & 83.3 \\
\hline Std. Dev. & 1.3 & 8.9 & 10.9 & 10.5 \\
\hline
\end{tabular}




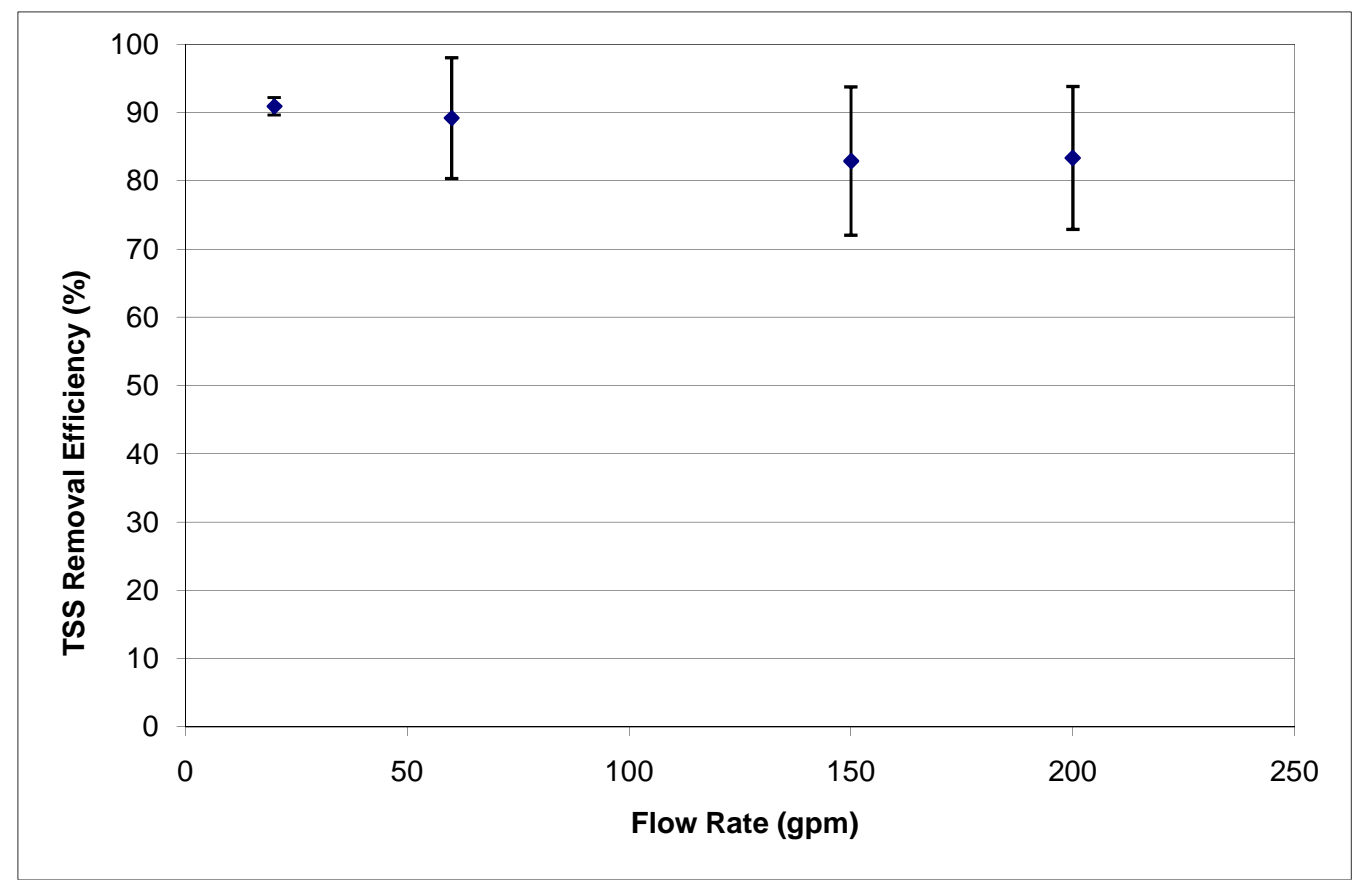

Figure 17. DrainPac ${ }^{\circledR}$ filter sediment removal efficiency (error bars indicate standard deviations)

\subsubsection{Oil and Grease Removal by the Full-Scale DrainPac ${ }^{\circledR}$ Filter}

Oil concentrations of three consecutive influent and effluent sample pairs at four different flow rates were determined gravimetrically by extracting oil/water samples into hexane and evaporating off the hexane. Influent concentrations were as high as $45.4 \mathrm{mg} / \mathrm{L}$ while effluent concentrations ranged from 2.6 to $9.7 \mathrm{mg} / \mathrm{L}$ (Table 11). Average oil removal efficiencies ranged from $40 \%$ to $82 \%$ as shown in Table 12 and Figure 18. Based on the high standard deviations (Table 12) and error bars in Figure 18, there was no discernible trend of oil removal efficiency with flow rate. High standard deviations in oil removal efficiencies could be due to the low concentrations of oil that were present in influent and effluent samples, making gravimetric measurement errors more significant. Metering in 
oil at a higher loading rate would result in higher influent oil concentrations and could lead to more consistent results.

Table 11. Oil concentration in water before and after DrainPac ${ }^{\circledR}$ filter at various flow rates

\begin{tabular}{|c|c|c|c|c|c|}
\hline \multirow{2}{*}{ Sample } & \multirow{2}{*}{ Replicate } & \multicolumn{4}{|c|}{ Oil Concentration in Water (mg/L) } \\
\cline { 3 - 6 } & & $20 \mathrm{gpm}$ & $60 \mathrm{gpm}$ & $150 \mathrm{gpm}$ & $200 \mathrm{gpm}$ \\
\hline \multirow{3}{*}{ Influent } & 1 & 16.9 & 14.3 & 11.5 & 45.4 \\
\cline { 2 - 6 } & 2 & 21.9 & 3.6 & 15.5 & 17.3 \\
\cline { 2 - 6 } & 3 & 14.6 & 14.9 & 12.2 & 27.0 \\
\hline \multirow{3}{*}{ Effluent } & 1 & 9.7 & 2.6 & 6.8 & 7.2 \\
\cline { 2 - 6 } & 2 & 8.8 & 4.9 & 6.6 & 4.6 \\
\cline { 2 - 6 } & 3 & 8.4 & 6.7 & 9.6 & 3.2 \\
\hline
\end{tabular}

Table 12. DrainPac ${ }^{\circledR}$ filter oil removal efficiency

\begin{tabular}{|c|c|c|}
\hline Flow Rate (gpm) & $\begin{array}{c}\text { Average Removal Efficiency } \\
(\%)\end{array}$ & $\begin{array}{c}\text { Standard } \\
\text { Deviation }\end{array}$ \\
\hline 20 & 48.5 & 9.7 \\
\hline 60 & 68.4 & 18.7 \\
\hline 150 & 40.0 & 18.1 \\
\hline 200 & 81.8 & 7.7 \\
\hline
\end{tabular}




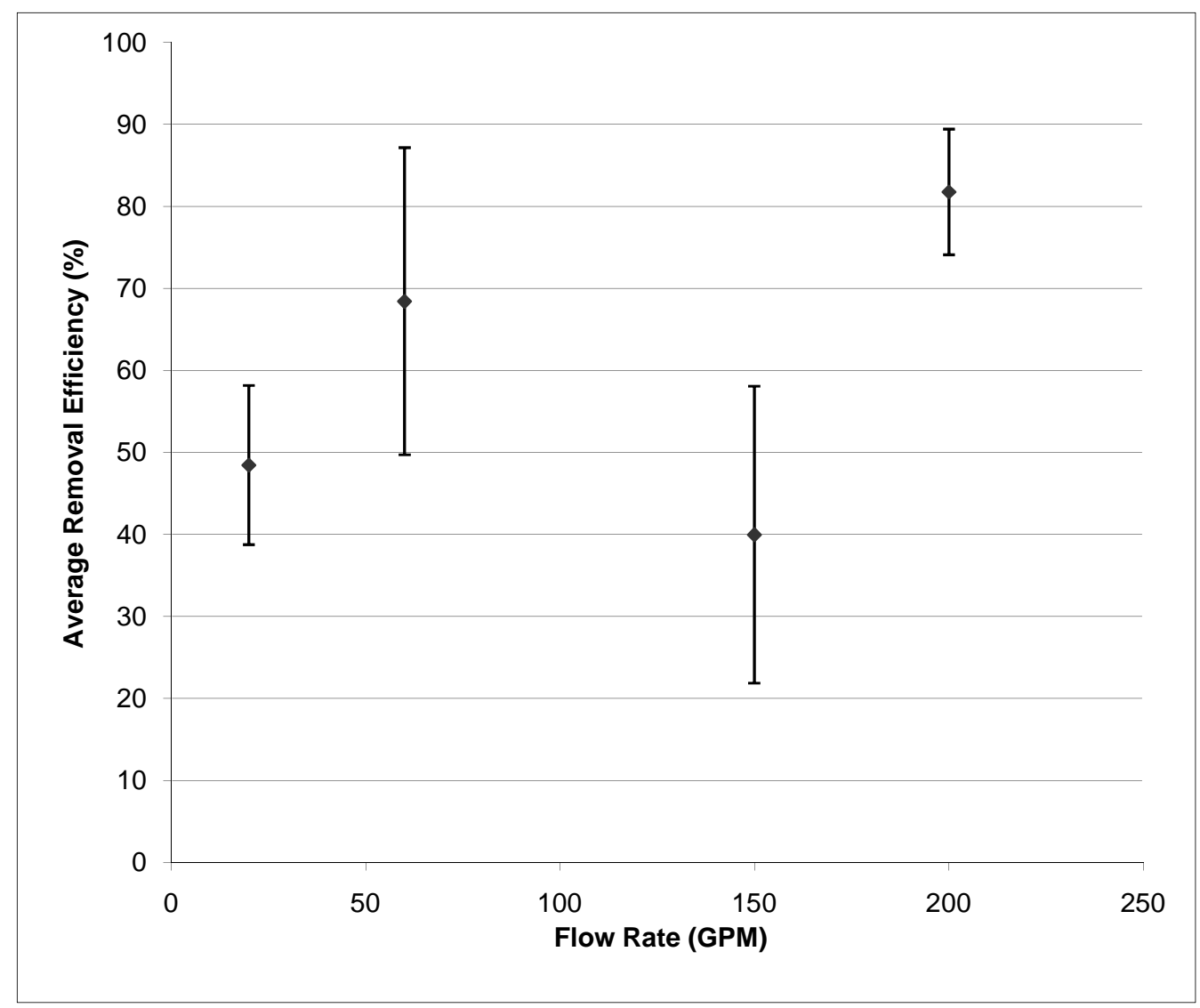

Figure 18. DrainPac ${ }^{\circledR}$ filter oil removal efficiency at various flow rates

\subsubsection{Coliform Removal by the Full-Scale DrainPac ${ }^{\circledR}$ Filter}

The DrainPac ${ }^{\circledR}$ filter showed no evidence of coliform bacteria removal, in fact higher coliform counts were observed in the effluent water than the influent water at all tested flow rates (Table 13). Higher coliform counts in the effluent water were likely due to the high variability of microbiological analyses, so it was concluded that the DrainPac ${ }^{\circledR}$ filter does not remove coliform bacteria. At flow rates of 60, 150, and $200 \mathrm{gpm}$, the average effluent coliform concentrations were 4 to $19 \%$ higher than the average influent concentrations. However, at a flow rate of $20 \mathrm{gpm}$, the average effluent coliform 
concentration was $44 \%$ higher than the average influent coliform concentration. It is likely that given the small colloidal size of bacteria, they were flowing through the fabric filter. This test was only conducted with a small accumulation of solids from the pond water. Better coliform removal might be achieved if a layer of solids develops on the filter, like a schmutzdecker in a slow sand filter. Possible future research could test whether the addition of solids and the development of a filter cake could increase the bacterial removal efficiency of the filter.

\section{Table 13. DrainPac ${ }^{\circledR}$ filter coliform removal results at various flow rates}

\begin{tabular}{|c|c|c|}
\hline \multirow{2}{*}{$\begin{array}{c}\text { Flow } \\
\text { Rate } \\
\text { (gpm) }\end{array}$} & \multicolumn{2}{|c|}{$\begin{array}{c}\text { Average Coliform Bacteria } \\
\text { Concentration (CFU/100 mL) }\end{array}$} \\
\cline { 2 - 3 } & Influent & Effluent \\
\hline 20 & $1931(430)$ & $3423(616)$ \\
\hline 60 & $2561(450)$ & $2668(219)$ \\
\hline 150 & $2495(702)$ & $2676(865)$ \\
\hline 200 & $2267(408)$ & $2783(414)$ \\
\hline
\end{tabular}

*Average of triplicate samples, standard deviations in parentheses 


\subsection{BiocidAl BEAD RESUlTS}

\subsubsection{Laboratory Column and Biocidal Bead Head Loss Results}

Head losses through a 1-cm bed of $0.3-\mathrm{mm}$ beads in the laboratory column increased with increasing flow rates (Table 14). The head loss due to the empty column apparatus alone was very low $(0.8-1.5 \mathrm{~cm})$ and considered negligible (Figure 19). The head loss due to the glass wool was significant, but much less than when the beads were present. Head loss through the glass wool increased linearly with flow rate (Figure 19). The head losses due to the beads alone were determined by subtracting the head loss of the glass wool and column apparatus from the total head loss (Table14).

Table 14. 0.3 mm Biocidal bead head loss results

\begin{tabular}{|c|c|c|c|c|c|c|}
\hline \multirow[b]{2}{*}{$\begin{array}{l}\text { Flow Rate } \\
\text { (mL/sec) }\end{array}$} & \multirow[b]{2}{*}{$\begin{array}{l}\text { Superficial } \\
\text { Velocity in } \\
\text { Column } \\
(\mathrm{cm} / \mathrm{sec})\end{array}$} & \multirow[b]{2}{*}{$\begin{array}{c}\text { Equivalent Flow } \\
\text { Rate in DrainPac } \\
\text { Filter (gpm) }\end{array}$} & \multicolumn{4}{|c|}{ Head Loss $(\mathrm{cm})$} \\
\hline & & & $\begin{array}{l}\text { Glass } \\
\text { Column }\end{array}$ & $\begin{array}{c}\text { Glass Column } \\
\text { with Glass } \\
\text { Wool }\end{array}$ & $\begin{array}{c}\text { Glass } \\
\text { Column, } \\
\text { Glass Wool, } \\
\text { and } 1 \mathrm{~cm} \text { of } \\
\text { Beads }\end{array}$ & $\begin{array}{l}\text { Beads } \\
\text { Alone }\end{array}$ \\
\hline 0.28 & 0.36 & 18 & 0.8 & 11 & 30 & 19 \\
\hline 0.56 & 0.71 & 36 & 0.9 & 17.2 & 48 & 30.8 \\
\hline 0.84 & 1.07 & 54 & 1.1 & 28 & 64 & 36 \\
\hline 1.12 & 1.43 & 72 & 1.3 & 35 & 80.5 & 45.5 \\
\hline 1.4 & 1.78 & 90 & 1.5 & 42.5 & 94.2 & 51.7 \\
\hline
\end{tabular}




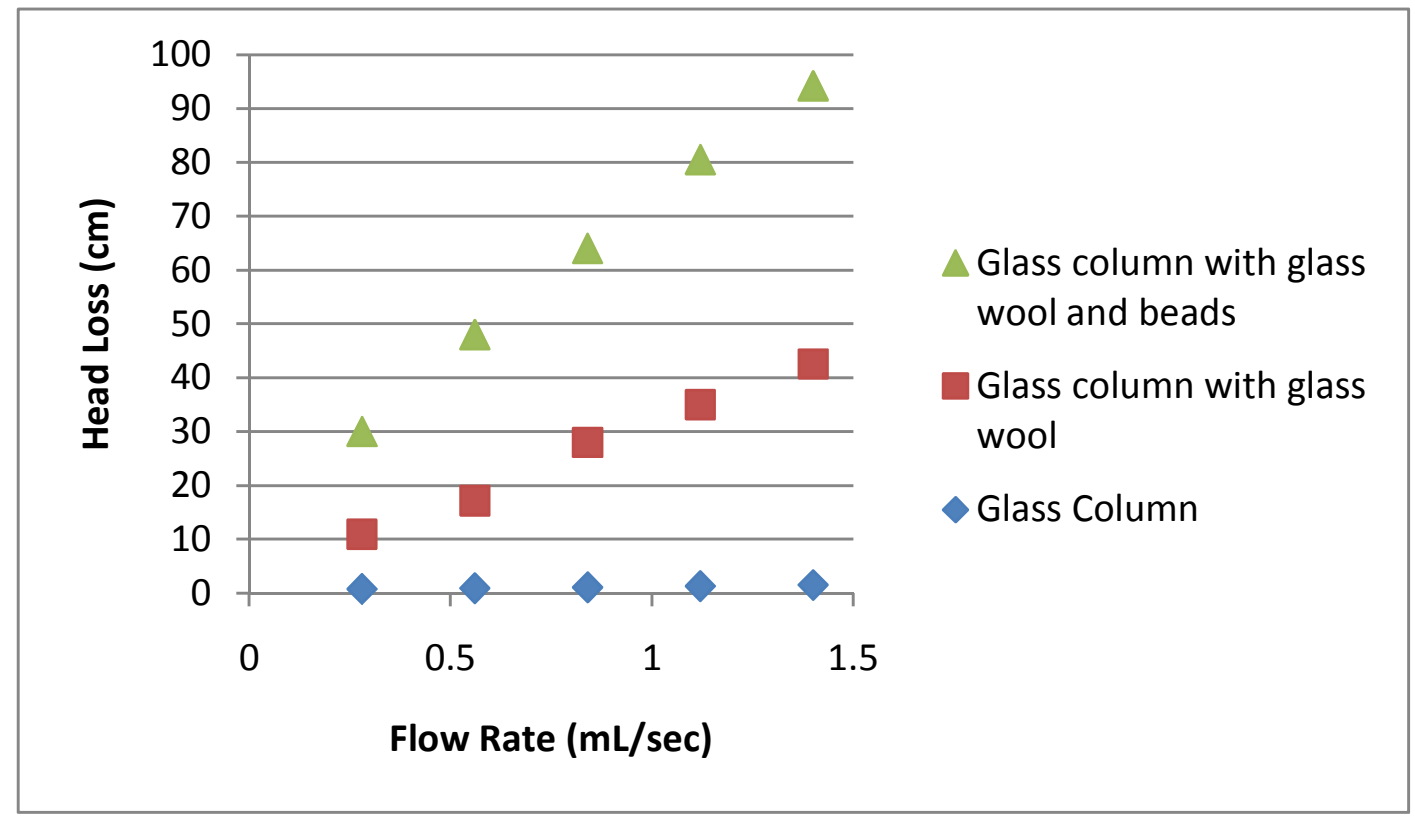

Figure 19. 0.3 mm Biocidal bead head loss results

Head loss for the 0.8 - $\mathrm{mm}$ biocidal beads followed a similar trend as the $0.3 \mathrm{~mm}$ beads, with head loss increasing linearly with flow rate (Figure 20). The head losses of the beads alone at various flow rates are displayed in Table 15. Figure 20 displays the trend of increasing head loss with an increase in flow rate.

Table 15. 0.8 mm Biocidal bead head loss results

\begin{tabular}{|c|c|c|c|c|c|c|}
\hline \multirow[b]{2}{*}{$\begin{array}{l}\text { Flow Rate } \\
\text { (mL/sec) }\end{array}$} & \multirow[b]{2}{*}{$\begin{array}{l}\text { Superficial } \\
\text { Velocity in } \\
\text { Column } \\
(\mathrm{cm} / \mathrm{sec})\end{array}$} & \multirow[b]{2}{*}{$\begin{array}{l}\text { Equivalent Flow } \\
\text { Rate in Drain } \\
\text { Pac Filter (gpm) }\end{array}$} & \multicolumn{4}{|c|}{ Head Loss $(\mathrm{cm})$} \\
\hline & & & $\begin{array}{l}\text { Glass } \\
\text { Column }\end{array}$ & $\begin{array}{c}\text { Glass Column } \\
\text { with Glass } \\
\text { Wool }\end{array}$ & $\begin{array}{c}\text { Glass } \\
\text { Column, } \\
\text { Glass Wool, } \\
\text { and } 1 \mathrm{~cm} \text { of } \\
\text { Beads }\end{array}$ & $\begin{array}{l}\text { Beads } \\
\text { Alone }\end{array}$ \\
\hline 0.28 & 0.36 & 10 & 0.4 & 9.4 & 21.3 & 11.9 \\
\hline 0.56 & 0.71 & 20 & 0.5 & 16.7 & 40.5 & 23.8 \\
\hline 0.84 & 1.07 & 30 & 0.6 & 23.1 & 56 & 32.9 \\
\hline 1.12 & 1.43 & 40 & 0.8 & 28.9 & 69.9 & 41 \\
\hline 1.4 & 1.78 & 50 & 1.1 & 37.3 & 85 & 47.7 \\
\hline
\end{tabular}




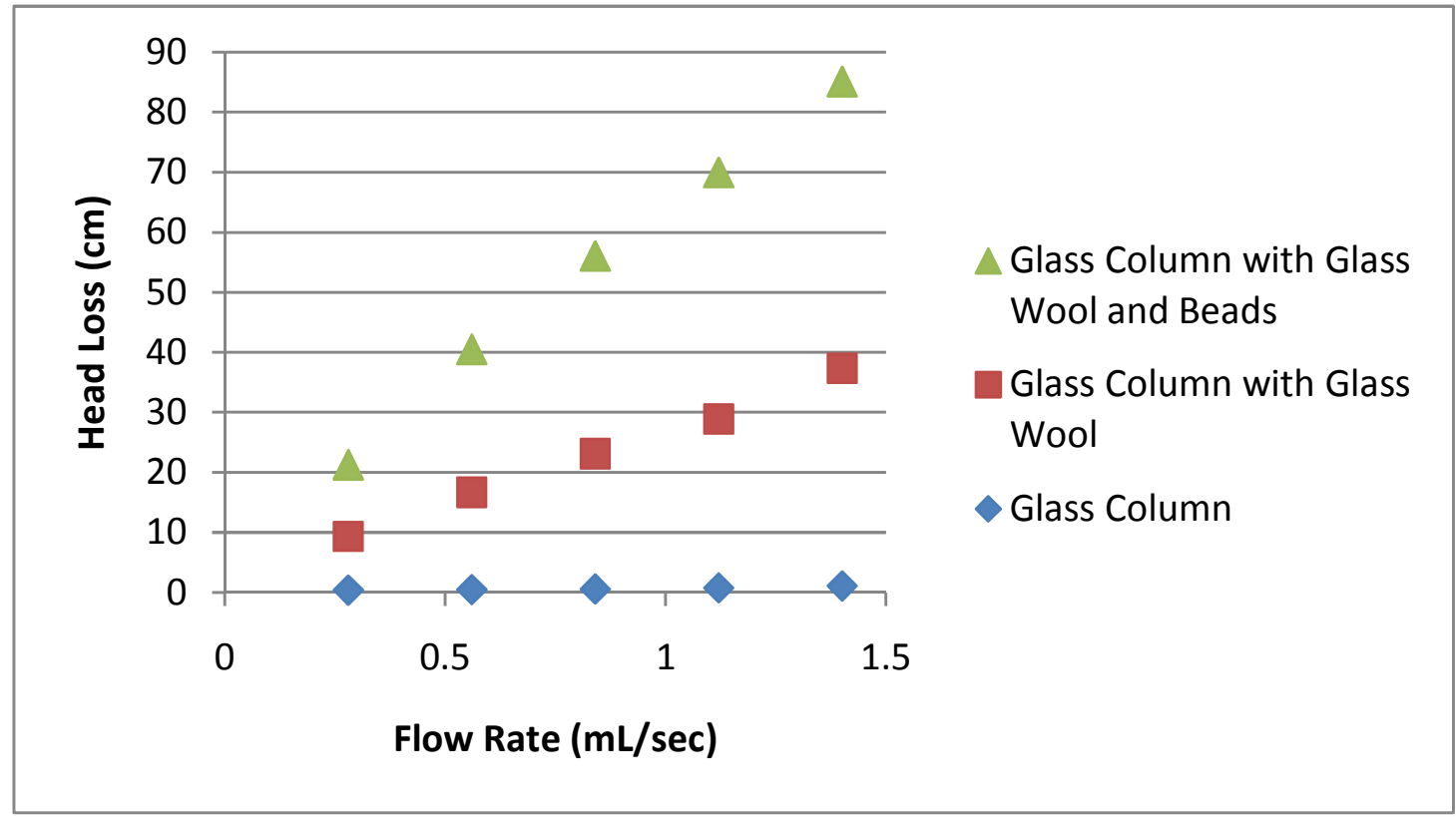

Figure 20. $0.8 \mathrm{~mm}$ Biocidal bead head loss results

Head losses of the $0.3 \mathrm{~mm}$ and $0.8 \mathrm{~mm}$ biocidal beads alone followed a linear relationship with flow rate (Figure 21). The head losses of the $0.8 \mathrm{~mm}$ beads were consistently lower than the head losses of the $0.3 \mathrm{~mm}$ beads at all flow rates, however, the difference in head losses were slightly greater at lower flow rates than at higher flow rates (Figure 21). For instance, the head loss of the $0.3 \mathrm{~mm}$ beads alone at the lowest flow rate was $37 \%$ higher than the head loss of the $0.8 \mathrm{~mm}$ beads. At the highest two flow rates $(1.12$ and $1.4 \mathrm{~mL} / \mathrm{sec})$ the head losses of the $0.3 \mathrm{~mm}$ beads alone were only $10 \%$ and $8 \%$ higher, respectively than the head losses of the $0.8 \mathrm{~mm}$ beads (Tables 14 and 15).

At the higher flow rates of 1.12 and $1.4 \mathrm{~mL} / \mathrm{sec}$, the head loss of the beads alone exceeded $38 \mathrm{~cm}$. Since this exceeds the $30.5-38 \mathrm{~cm}$ manufactured depth of the DrainPac ${ }^{\circledR}$ filter, subsequent column tests were only conducted at the lowest three flow 
rates of $0.28,0.56$, and $0.84 \mathrm{~mL} / \mathrm{sec}$, equivalent to 18,36 , and $54 \mathrm{gpm}$ through the DrainPac ${ }^{\circledR}$ filter.

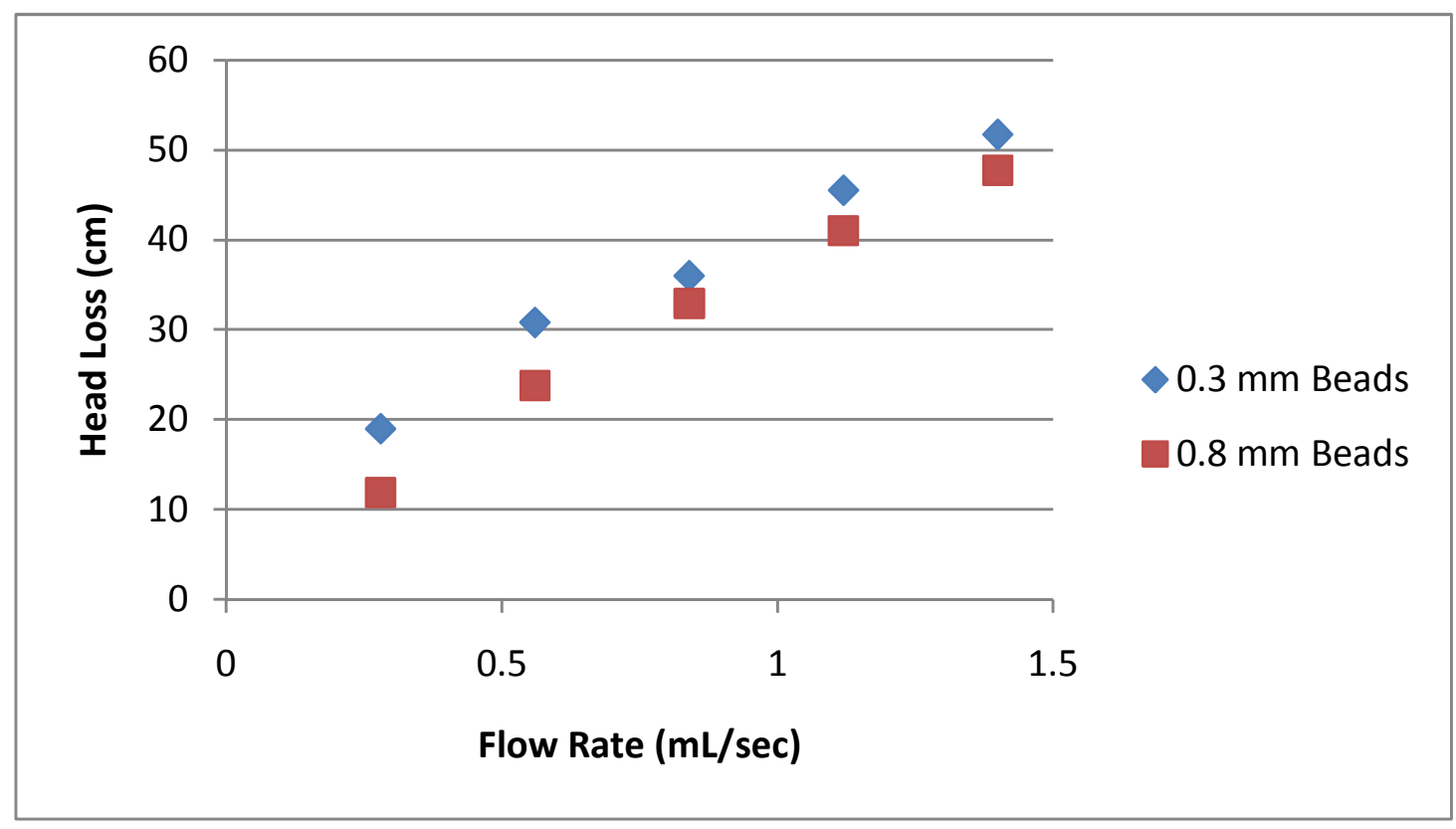

Figure 21. Biocidal bead size and head loss comparison

\subsubsection{Bromine Leaching Results}

Bromine concentrations of water passed through a 1-cm deep bed of $0.3 \mathrm{~mm}$ beads, 0.8 $\mathrm{mm}$ beads, and $0.8 \mathrm{~mm}$ unactivated control beads at a flow rate of $0.56 \mathrm{~mL} / \mathrm{sec}$ are shown in Table 16. The pond water effluent that passed through the $0.3 \mathrm{~mm}$ beads had an average bromine concentration of $0.47 \mathrm{mg} / \mathrm{L}$, which was nearly double the average concentration leached from the activated $0.8 \mathrm{~mm}$ beads $(0.27 \mathrm{mg} / \mathrm{L})$. The bromine concentration in the initial DI flush water from the $0.3 \mathrm{~mm}$ beads was also nearly double the concentration in the DI flush water of the $0.8 \mathrm{~mm}$ beads (Table 16). The higher bromine concentrations in the $0.3 \mathrm{~mm}$ bead effluent is likely partly due to the larger surface area of the $0.3 \mathrm{~mm}$ beads, allowing for greater mass transfer capabilities than the 
$0.8 \mathrm{~mm}$ beads. However, the formulation used by the manufacturer for charging the beads was different for the two bead sizes.

As expected, the $0.8 \mathrm{~mm}$ inactivated (unbrominated) control beads showed no leaching of bromine at all (Table 16). The color from the $\mathrm{Hach}^{\circledR}$ test kit was completely clear, suggesting a $0 \mathrm{mg} / \mathrm{L}$ bromine concentration.

Table 16. Effluent bromine concentrations from the laboratory column with $0.3 \mathrm{~mm}$ and $0.8 \mathrm{~mm}$ biocidal beads at $0.56 \mathrm{~mL} / \mathrm{sec}$

\begin{tabular}{|c|c|c|}
\hline $\begin{array}{l}\text { Testing } \\
\text { Scenario }\end{array}$ & Sample & $\begin{array}{c}\text { Bromine Concentration } \\
(\mathrm{mg} / \mathrm{L})\end{array}$ \\
\hline \multirow{5}{*}{$\begin{array}{l}0.3 \mathrm{~mm} \\
\text { beads }\end{array}$} & DI Flush Water & 0.9 \\
\hline & Pond 1 & 0.5 \\
\hline & Pond 2 & 0.5 \\
\hline & Pond 3 & 0.4 \\
\hline & Pond average & 0.47 \\
\hline \multirow{5}{*}{$\begin{array}{l}0.8 \mathrm{~mm} \\
\text { beads }\end{array}$} & DI Flush Water & 0.5 \\
\hline & Pond 1 & 0.3 \\
\hline & Pond 2 & 0.3 \\
\hline & Pond 3 & 0.2 \\
\hline & Pond average & 0.27 \\
\hline \multirow{4}{*}{$\begin{array}{c}0.8 \mathrm{~mm} \\
\text { Inactivated } \\
\text { beads }\end{array}$} & DI Flush Water & 0 \\
\hline & Pond 1 & 0 \\
\hline & Pond 2 & 0 \\
\hline & Pond 3 & 0 \\
\hline
\end{tabular}

To compare expected mass transfer rates of bromine from the two bead sizes, the surface area in a given bed volume for both size beads was calculated by measuring the void fraction (volume of voids divided by the total bed volume). The void fraction $(\varepsilon)$ and 
bead diameter $\left(D_{p}\right)$ were then used to calculate $a$, the surface area of the beads per bed volume $\left(\mathrm{cm}^{2} / \mathrm{cm}^{3}\right)$ using the following equation (Geankoplis, 2003):

$$
\begin{aligned}
& a_{0.3 \mathrm{~mm} \text { beads }}=\frac{6(1-\varepsilon)}{D_{p}}=\frac{6(1-0.546)}{0.03 \mathrm{~cm}}=90.8 \mathrm{~cm}^{2} / \mathrm{cm}^{3} \\
& a_{0.8 \mathrm{~mm} \text { beads }}=\frac{6(1-\varepsilon)}{D_{p}}=\frac{6(1-0.692)}{0.08 \mathrm{~cm}}=23.0 \mathrm{~cm}^{2} / \mathrm{cm}^{3}
\end{aligned}
$$

The surface area in a column packed with a 1-cm depth of beads is as follows:

$$
\begin{aligned}
& A_{0.3 \mathrm{~mm} \text { beads }}=90.8 \frac{\mathrm{cm}^{2}}{\mathrm{~cm}^{3}} * \frac{\pi}{4} *(1 \mathrm{~cm})^{2} * 1 \mathrm{~cm}=71.3 \mathrm{~cm}^{2} \\
& A_{0.8 \mathrm{~mm} \text { beads }}=23.0 \frac{\mathrm{cm}^{2}}{\mathrm{~cm}^{3}} * \frac{\pi}{4} *(1 \mathrm{~cm})^{2} * 1 \mathrm{~cm}=18.1 \mathrm{~cm}^{2}
\end{aligned}
$$

Thus the available surface area in a column packed with a $1-\mathrm{cm}$ depth of $0.3 \mathrm{~mm}$ beads is nearly 4 times greater than the total surface area in a column packed with a $1-\mathrm{cm}$ depth of $0.8 \mathrm{~mm}$ beads. This allows for much greater mass transfer of bromine from the $0.3 \mathrm{~mm}$ beads, which explains the higher leaching rate of bromine from the $0.3 \mathrm{~mm}$ beads. 


\subsubsection{Bromoform Results}

Average bromoform concentrations in the pond water that passed through the $1 \mathrm{~cm} x 1$ $\mathrm{cm}$ column of $0.3 \mathrm{~mm}$ beads ranged from $0.14 \mathrm{mg} / \mathrm{L}$ to over $13 \mathrm{mg} / \mathrm{L}$, as shown in Table 17. The quenching scenario had a dramatic effect on bromoform measured. Unquenched sample bromoform concentrations were consistently higher, most likely due to the longer contact times allowing for more formation of bromoform by the reaction of bromine with organic matter in the pond water. To compare the bromoform concentrations in water from different flow rates, data with the identical quenching scenario must be used. At a flow rate of $0.56 \mathrm{~mL} / \mathrm{sec}$ with the sample quenched after collection, the $0.3 \mathrm{~mm}$ beads leached approximately $2.45 \mathrm{mg} / \mathrm{L}$ bromoform, which is much higher than the $0.14 \mathrm{mg} / \mathrm{L}$ average bromoform concentration in the water that passed through the beads at a 0.84 $\mathrm{mL} / \mathrm{sec}$ flow rate under the same quenching condition. The bromoform concentration is likely higher from the $0.56 \mathrm{~mL} / \mathrm{sec}$ flow rate sample because at that flow rate, the water contact time with the beads is nearly 1.5 times greater than at a flow rate of $0.84 \mathrm{~mL} / \mathrm{sec}$. DI flush water at $0.28 \mathrm{~mL} / \mathrm{sec}$ contained $1.25 \mathrm{mg} / \mathrm{L}$ bromoform (Table 17), which seems high since there are no organics present in DI water, which are expected to react with bromine by reducing it to bromide, forming bromoform (Westerhoff, et al., 2004). It is possible that bromoform could have leached from the surface of the $0.3 \mathrm{~mm}$ beads since bromoform was formed without the presence of organics in the DI flush water. 
Table 17. Effluent bromoform concentrations from $0.3 \mathrm{~mm}$ biocidal beads

\begin{tabular}{|c|c|c|c|c|c|c|c|}
\hline $\begin{array}{l}\text { Flow } \\
\text { Rate }\end{array}$ & $\begin{array}{l}\text { Quenching } \\
\text { Scenario }\end{array}$ & Sample & $\begin{array}{c}\text { GC Peak } \\
\text { Area }\end{array}$ & $\begin{array}{c}\text { Concentration } \\
\text { Factor }^{*}\end{array}$ & $\begin{array}{c}\text { Bromoform } \\
\text { Concentration } \\
\text { in Water } \\
(\mathrm{mg} / \mathrm{L}) \\
\end{array}$ & $\begin{array}{c}\text { Average } \\
\text { Bromoform } \\
\begin{array}{c}\text { Concentration } \\
(\mathrm{mg} / \mathrm{L})\end{array} \\
\end{array}$ & $\begin{array}{l}\text { Coefficient of } \\
\text { Variance }\end{array}$ \\
\hline $\begin{array}{ll}\infty & 0 \\
0 \\
\stackrel{d}{0} \\
0 \\
0\end{array}$ & $\begin{array}{l}\text { Quenched } \\
\text { after sample } \\
\text { collected }\end{array}$ & $\begin{array}{l}\text { DI } \\
\text { Flush }\end{array}$ & 721007 & 20 & 1.25 & 1.25 & ----- \\
\hline \multirow{8}{*}{$\begin{array}{l}0 \\
0 \\
\infty \\
D \\
\\
E \\
0 \\
0 \\
0 \\
0\end{array}$} & \multirow{2}{*}{$\begin{array}{c}\text { Quenched } \\
\text { immediately }\end{array}$} & 1 & 455343 & 16.13 & 0.98 & \multirow{2}{*}{1.17} & \multirow{2}{*}{$22.3 \%$} \\
\hline & & 2 & 744394 & 19.23 & 1.35 & & \\
\hline & \multirow{2}{*}{$\begin{array}{l}\text { Quenched } \\
\text { after sample } \\
\text { collected }\end{array}$} & 1 & 1608096 & 20.83 & 2.69 & \multirow{2}{*}{2.45} & \multirow{2}{*}{$13.9 \%$} \\
\hline & & 2 & 1321779 & 20.83 & 2.21 & & \\
\hline & \multirow{2}{*}{$\begin{array}{l}\text { Quenched } \\
\text { after } 10 \mathrm{~min} .\end{array}$} & 1 & 150283 & 19.61 & 0.27 & \multirow{2}{*}{0.38} & \multirow{2}{*}{$42.1 \%$} \\
\hline & & 2 & 262203 & 18.52 & 0.49 & & \\
\hline & \multirow{2}{*}{ Unquenched } & 1 & 5579696 & 19.23 & 10.10 & \multirow{2}{*}{13.4} & \multirow{2}{*}{$34.7 \%$} \\
\hline & & 2 & 9978720 & 20.83 & 16.67 & & \\
\hline \multirow{8}{*}{ 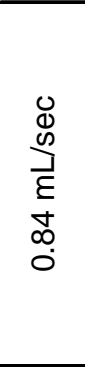 } & \multirow{2}{*}{$\begin{array}{l}\text { Quenched } \\
\text { immediately }\end{array}$} & 1 & 1340391 & 20 & 2.33 & \multirow{2}{*}{2.43} & \multirow{2}{*}{$5.8 \%$} \\
\hline & & 2 & 1192262 & 16.4 & 2.53 & & \\
\hline & \multirow{2}{*}{$\begin{array}{l}\text { Quenched } \\
\text { after sample } \\
\text { collected }\end{array}$} & 1 & 84793 & 20.83 & 0.14 & \multirow{2}{*}{0.14} & \multirow{2}{*}{$20.9 \%$} \\
\hline & & 2 & 80112 & 19.23 & 0.15 & & \\
\hline & \multirow{2}{*}{$\begin{array}{l}\text { Quenched } \\
\text { after } 10 \mathrm{~min} .\end{array}$} & 1 & 240502 & 20.83 & 0.40 & \multirow{2}{*}{0.55} & \multirow{2}{*}{$36.7 \%$} \\
\hline & & 2 & 412148 & 20.83 & 0.69 & & \\
\hline & \multirow{2}{*}{ Unquenched } & 1 & 3803805 & 20.41 & 6.49 & \multirow{2}{*}{6.98} & \multirow{2}{*}{$10.0 \%$} \\
\hline & & 2 & 4380874 & 20.41 & 7.47 & & \\
\hline
\end{tabular}

* Based on the final concentrated $\mathrm{MeCl}$ volume of the $100-\mathrm{mL}$ aliquots (roughly $5 \mathrm{~mL}$ )

The $0.8 \mathrm{~mm}$ beads were tested at 0.56 and $0.28 \mathrm{~mL} / \mathrm{sec}$ flow rates, equivalent to 18 and 36 gpm, respectively, through a 12 x 41 in. DrainPac ${ }^{\circledR}$ filter. Bromoform concentrations leached from the $0.8 \mathrm{~mm}$ beads proved to be much lower than from the $0.3 \mathrm{~mm}$ beads, with all samples less than $0.1 \mathrm{mg} / \mathrm{L}$ (Table 18). A blind duplicate of the $0.28 \mathrm{~mL} / \mathrm{sec}$ flow rate sample that was quenched after sample collection was sent to Creek Environmental Laboratories, Inc. (San Luis Obispo) and analyzed for bromoform for quality control. Creek Environmental Laboratories, Inc. reported a bromoform concentration of $0.044 \mathrm{mg} / \mathrm{L}$ in water. This compares favorably with my internal GC/MS analysis which gave a value of $0.05 \mathrm{mg} / \mathrm{L}$ (Table 18 ). Pond water that had not passed through the beads was also analyzed for bromoform by GC/MS, and this pond water 
blank produced a peak area corresponding to a concentration of $0.02 \mathrm{mg} / \mathrm{L}$ bromoform, which is below the lower detection limit $(0.025 \mathrm{mg} / \mathrm{L})$. Unlike DI flush water effluent from the $0.3 \mathrm{~mm}$ beads, the bromoform concentration of DI flush water from $0.8 \mathrm{~mm}$ beads was below detection (Table18). This is likely due to the different manufacturing process of the $0.8 \mathrm{~mm}$ beads.

Table 18. Effluent bromoform concentrations from $0.8 \mathrm{~mm}$ biocidal beads

\begin{tabular}{|c|c|c|c|c|c|c|c|}
\hline Flow Rate & $\begin{array}{l}\text { Quenching } \\
\text { Scenario }\end{array}$ & Sample & Area & $\begin{array}{c}\text { Concentration } \\
\text { Factor }\end{array}$ & $\begin{array}{c}\text { Bromoform } \\
\text { Concentration } \\
\text { in Water } \\
(\mathrm{mg} / \mathrm{L})\end{array}$ & $\begin{array}{c}\text { Average } \\
\text { Bromoform } \\
\text { Concentration } \\
(\mathrm{mg} / \mathrm{L})\end{array}$ & $\begin{array}{l}\text { Coefficient } \\
\text { of Variance }\end{array}$ \\
\hline \multirow{6}{*}{$0.56 \mathrm{~mL} / \mathrm{sec}$} & \multirow{2}{*}{$\begin{array}{l}\text { Quenched } \\
\text { immediately }\end{array}$} & 1 & 5649 & 16.13 & 0.01 & \multirow{2}{*}{0.05} & \multirow{2}{*}{$104.9 \%$} \\
\hline & & 2 & 45434 & 19.23 & 0.08 & & \\
\hline & \multirow{2}{*}{$\begin{array}{l}\text { Quenched } \\
\text { after sample } \\
\text { collected }\end{array}$} & 1 & 23762 & 20.83 & 0.04 & \multirow{2}{*}{0.06} & \multirow{2}{*}{$43.2 \%$} \\
\hline & & 2 & 44657 & 20.83 & 0.07 & & \\
\hline & \multirow{2}{*}{$\begin{array}{l}\text { Quenched } \\
\text { after } 10 \mathrm{~min} .\end{array}$} & 1 & 32949 & 19.61 & 0.06 & \multirow{2}{*}{0.04} & \multirow{2}{*}{$78.9 \%$} \\
\hline & & 2 & 8823 & 18.52 & 0.02 & & \\
\hline \multirow{4}{*}{$0.28 \mathrm{~mL} / \mathrm{sec}$} & Quenched & 1 & 31667 & 20.80 & 0.05 & \multirow{2}{*}{0.05} & \multirow{2}{*}{$1.1 \%$} \\
\hline & collected $^{*}$ & 2 & 30279 & 19.60 & 0.05 & & \\
\hline & $\begin{array}{c}\text { Quenched } \\
\text { after Sample }\end{array}$ & DI Flush & 6656 & 20 & 0.01 & 0.01 & \\
\hline & $\begin{array}{c}\text { Pond Water } \\
\text { Blank }\end{array}$ & 1 & 13974 & 20.00 & 0.02 & 0.02 & \\
\hline
\end{tabular}

*Blind duplicate sample analyzed for bromoform by Creek Environmental Inc. (San Luis Obispo) with a reported bromoform concentration of $0.044 \mathrm{mg} / \mathrm{L}$

\subsubsection{Bromide Results}

For the $0.3 \mathrm{~mm}$ beads, the average bromide concentration in the DI flush water effluent was $0.64 \mathrm{mg} / \mathrm{L}$ (Table 19.) The average pond water effluent bromide concentration for the $0.3 \mathrm{~mm}$ beads at a flow rate of $0.56 \mathrm{~mL} / \mathrm{sec}$ was $0.53 \mathrm{mg} / \mathrm{L}$. 


\section{Table 19. Effluent bromide concentrations from $0.3 \mathrm{~mm}$ biocidal beads at 0.56 $\mathrm{mL} / \mathrm{sec}$}

\begin{tabular}{|c|c|c|c|c|}
\hline Sample* & Area & Retention Time & $\begin{array}{c}\text { Bromide } \\
\text { Concentration } \\
(\mathrm{mg} / \mathrm{L})\end{array}$ & $\begin{array}{c}\begin{array}{c}\text { Average } \\
\text { Concentration } \\
(\mathrm{mg} / \mathrm{L})\end{array} \\
\end{array}$ \\
\hline DI Water 1 a & 0.055 & 7.17 & 0.60 & \multirow{2}{*}{0.64} \\
\hline DI Water $1 \mathrm{~b}$ & 0.063 & 7.25 & 0.69 & \\
\hline Pond $1 \mathrm{a}$ & 0.046 & 7.18 & 0.50 & \multirow{2}{*}{0.54} \\
\hline Pond $1 \mathrm{~b}$ & 0.053 & 7.20 & 0.58 & \\
\hline Pond 2 a & 0.050 & 7.22 & 0.54 & \multirow{2}{*}{0.52} \\
\hline Pond $2 \mathrm{~b}$ & 0.046 & 7.22 & 0.50 & \\
\hline Pond 3 a & 0.050 & 7.20 & 0.54 & \multirow{2}{*}{0.54} \\
\hline Pond $3 \mathrm{~b}$ & 0.050 & 7.22 & 0.54 & \\
\hline & & \multicolumn{2}{|c|}{ Pond Water Average $=$} & 0.53 \\
\hline
\end{tabular}

*Replicate samples labeled "a" or "b" and "DI Water" refers to DI flush water

The $0.8 \mathrm{~mm}$ beads were tested for bromide at two flow rates: 0.56 and $0.28 \mathrm{~mL} / \mathrm{sec}$, equivalent to 36 and $18 \mathrm{gpm}$ through a $12 \times 41$ in. DrainPac ${ }^{\circledR}$ filter, respectively. The average bromide concentration from pond water effluent from the $0.8 \mathrm{~mm}$ beads at 0.56 $\mathrm{mL} / \mathrm{sec}$ was $0.50 \mathrm{mg} / \mathrm{L}$ (Table 20). For this analysis, pond water blanks were also tested for bromide. Bromide in pond water was small with duplicate pond water blanks averaging $0.17 \mathrm{mg} / \mathrm{L}$ for the $0.56 \mathrm{~mL} / \mathrm{sec}$ flow rate test (Table 20) and $0.09 \mathrm{mg} / \mathrm{L}$ for the $0.28 \mathrm{~mL} / \mathrm{sec}$ flow rate test (Table 21). The average pond water effluent bromide concentration from $0.8 \mathrm{~mm}$ beads at $0.28 \mathrm{~mL} / \mathrm{sec}$ was $1.38 \mathrm{mg} / \mathrm{L}$ (Table 21), which is $64 \%$ higher than the $0.50 \mathrm{mg} / \mathrm{L}$ effluent bromide concentration from $0.8 \mathrm{~mm}$ beads at $0.56 \mathrm{~mL} / \mathrm{sec}$ (Table 20). This difference in bromide concentration is likely due to the longer retention time in the column at the lower flow rate.

In this analysis, the DI flush water contained significantly lower bromide concentrations than the pond water that was flushed through the beads. This is expected because 
bromide is formed when bromine is reduced as it oxidizes organic material such as that in the pond water. In both the $0.8 \mathrm{~mm}$ bead effluents at 0.28 and $0.56 \mathrm{~mL} / \mathrm{sec}$ flow rates, the average bromide concentration in the DI flush water was lower than the average pond water effluent (Tables 20 and 21).

Table 20. Effluent bromide concentrations from $0.8 \mathrm{~mm}$ biocidal beads at a 0.56 $\mathrm{mL} / \mathrm{sec}$ flow rate

\begin{tabular}{|c|c|c|c|c|}
\hline Sample & Area & Retention Time & $\begin{array}{c}\text { Bromide } \\
\text { Concentration } \\
(\mathrm{mg} / \mathrm{L})\end{array}$ & $\begin{array}{c}\text { Average } \\
\text { Concentration } \\
(\mathrm{mg} / \mathrm{L})\end{array}$ \\
\hline Pond Blank 1 & 0.015 & 7.07 & 0.19 & \multirow{2}{*}{0.17} \\
\hline Pond Blank 2 & 0.012 & 6.97 & 0.15 & \multirow{2}{*}{0.38} \\
\hline DI Water 1 a & 0.03 & 6.82 & 0.37 & \multirow{2}{*}{0.50} \\
\cline { 1 - 3 } DI Water 1 b & 0.032 & 6.82 & 0.39 & \\
\hline Pond 1 & 0.036 & 6.85 & 0.44 & \\
\hline Pond 2 & 0.057 & 6.92 & 0.68 & \\
\hline Pond 3 & 0.031 & 6.87 & 0.38 & \\
\hline
\end{tabular}

Table 21. Effluent bromide concentrations from $0.8 \mathrm{~mm}$ biocidal beads at a 0.28 $\mathrm{mL} / \mathrm{sec}$ flow rate

\begin{tabular}{|c|c|c|c|c|}
\hline Sample & Area & Retention Time & $\begin{array}{c}\text { Bromide } \\
\text { Concentration } \\
(\mathrm{mg} / \mathrm{L})\end{array}$ & $\begin{array}{c}\text { Average } \\
\text { Concentration } \\
(\mathrm{mg} / \mathrm{L})\end{array}$ \\
\cline { 1 - 4 } Pond Blank 1 & 0 & -------- & 0.00 & \multirow{2}{*}{0.09} \\
\cline { 1 - 3 } Pond Blank 2 & 0.014 & 7.30 & 0.17 & \multirow{2}{*}{0.30} \\
\hline DI Water 1 a & 0.026 & 7.12 & 0.30 & \multirow{2}{*}{1.38} \\
\cline { 1 - 3 } DI Water 1 b & 0.027 & 7.12 & 0.31 & \\
\hline Pond 1 & 0.164 & 7.30 & 1.77 & \\
\hline Pond 2 & 0.112 & 7.22 & 1.21 & \\
\hline Pond 3 & 0.108 & 7.18 & 1.17 & \\
\hline
\end{tabular}




\subsubsection{Bromine Compound Leaching During Longevity Testing}

\section{Simulated Use Cycles}

The laboratory column with $1-\mathrm{cm}$ bed depth of $0.3 \mathrm{~mm}$ biocidal beads, was subjected to five daily one-hour wet cycles at a flow rate of $0.56 \mathrm{~mL} / \mathrm{sec}$ and four daily drying cycles to test the longevity of the beads. Following the wet/dry cycles, leachate from the beads was tested as described above at a flow rate of $0.56 \mathrm{~mL} / \mathrm{sec}$ and analyzed for bromine, bromoform, and bromide.

The average bromine concentration leached from the $0.3 \mathrm{~mm}$ beads after five use cycles at $0.56 \mathrm{~mL} / \mathrm{sec}$ was $0.37 \mathrm{mg} / \mathrm{L}$ (Table 22). This was approximately $20 \%$ less than the average bromine concentration in the leachate from a bed of fresh $0.3 \mathrm{~mm}$ beads at the same flow rate. To put this in perspective, each wet cycle consisted of passing approximately 2 liters of pond water through the beads, equivalent to 2,135 gallons of stormwater passing through a 1 -cm thick layer of biocidal beads set in a $12 \mathrm{x} 41$ in. DrainPac ${ }^{\circledR}$ filter.

Table 22. Effluent bromine concentrations from $0.3 \mathrm{~mm}$ biocidal beads at 0.56 $\mathrm{mL} / \mathrm{sec}$ flow rate under simulated use longevity conditions

\begin{tabular}{|c|c|}
\hline Sample & Bromine Concentration (mg/L) \\
\hline Pond 1 & 0.30 \\
\hline Pond 2 & 0.40 \\
\hline Pond 3 & 0.40 \\
\hline Average & 0.37 \\
\hline
\end{tabular}

Effluent from the $0.3 \mathrm{~mm}$ longevity bead run was also analyzed for bromide. After five simulated use cycles, the average bromide concentration leached from the beads was 0.51 
$\mathrm{mg} / \mathrm{L}$ (Table 23). This is about the same as the average bromide concentration from fresh $0.3 \mathrm{~mm}$ beads tested at the same flow rate (Table 19). The average bromide concentration in the leachate from the longevity bead run is also about the same as that in the effluent from fresh $0.8 \mathrm{~mm}$ beads at the same flow rate (Table 20).

Table 23. Effluent bromide concentrations from $0.3 \mathrm{~mm}$ biocidal beads at 0.56 $\mathrm{mL} / \mathrm{sec}$ flow rate under longevity conditions

\begin{tabular}{|c|c|c|c|c|}
\hline Sample & Area & Retention Time & $\begin{array}{c}\text { Bromide } \\
\text { Concentration } \\
(\mathrm{mg} / \mathrm{L})\end{array}$ & $\begin{array}{c}\text { Average } \\
\text { Concentration } \\
(\mathrm{mg} / \mathrm{L})\end{array}$ \\
\hline 1 & 0.041 & 6.9 & 0.50 & \multirow{2}{*}{0.51} \\
\hline 2 & 0.042 & 6.9 & 0.51 & \multirow{2}{*}{0.51} \\
\hline 3 & 0.045 & 6.92 & 0.54 & \\
\hline
\end{tabular}

After the bromine was analyzed and the bromide was sampled, bromoform samples were collected and quenched with sodium thiosulfate immediately after each $147-\mathrm{mL}$ sample was collected. After the five use cycles, the average observed bromoform concentration in the leachate was $0.03 \mathrm{mg} / \mathrm{L}$ (Table 24). In comparison, the average bromoform concentration in the effluent from fresh $0.3 \mathrm{~mm}$ beads at the same flow rate and quenching scenario was $2.45 \mathrm{mg} / \mathrm{L}$.

Table 24. Effluent bromoform concentrations from $0.3 \mathrm{~mm}$ biocidal beads at 0.56 $\mathrm{mL} / \mathrm{sec}$ flow rate under longevity conditions

\begin{tabular}{|c|c|c|c|c|c|c|c|}
\hline \multirow{3}{*}{ 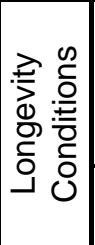 } & $\begin{array}{l}\text { Quenching } \\
\text { Scenario }\end{array}$ & Sample & Area & $\begin{array}{c}\text { Concentration } \\
\text { Factor }\end{array}$ & $\begin{array}{c}\text { Bromoform } \\
\text { Concentration } \\
\text { in Water } \\
(\mathrm{mg} / \mathrm{L})\end{array}$ & $\begin{array}{c}\text { Average } \\
\text { Concentration } \\
(\mathrm{mg} / \mathrm{L})\end{array}$ & $\begin{array}{l}\text { Coefficient } \\
\text { of Variance }\end{array}$ \\
\hline & Quenched & 1 & 21156 & 20.41 & 0.036 & \multirow[b]{2}{*}{0.03} & \multirow{2}{*}{0.53} \\
\hline & After Sample & 2 & 9646 & 20.41 & 0.016 & & \\
\hline
\end{tabular}

In summary, bromine and bromide concentrations in the leachate were similar before and after the five simulated use cycles (Figure 22). However, the leachate from the $0.3 \mathrm{~mm}$ 
beads that underwent five wet cycles and four dry cycles contained nearly 100 times less bromoform than pond water passed through fresh $0.3 \mathrm{~mm}$ beads. This suggests that much of the bromoform was exhausted sometime during the five simulated use cycles, possibly leaching off the surface of the beads. It is also possible that less bromoform was formed because less organic material was present in the pond water after the column of glass wool filtered the water prior to the column of beads. However, this may not be true since organic material also aids in the reduction of bromine into bromide, and bromide concentrations in the leachate were not significantly less than leachate from fresh $0.3 \mathrm{~mm}$ beads.

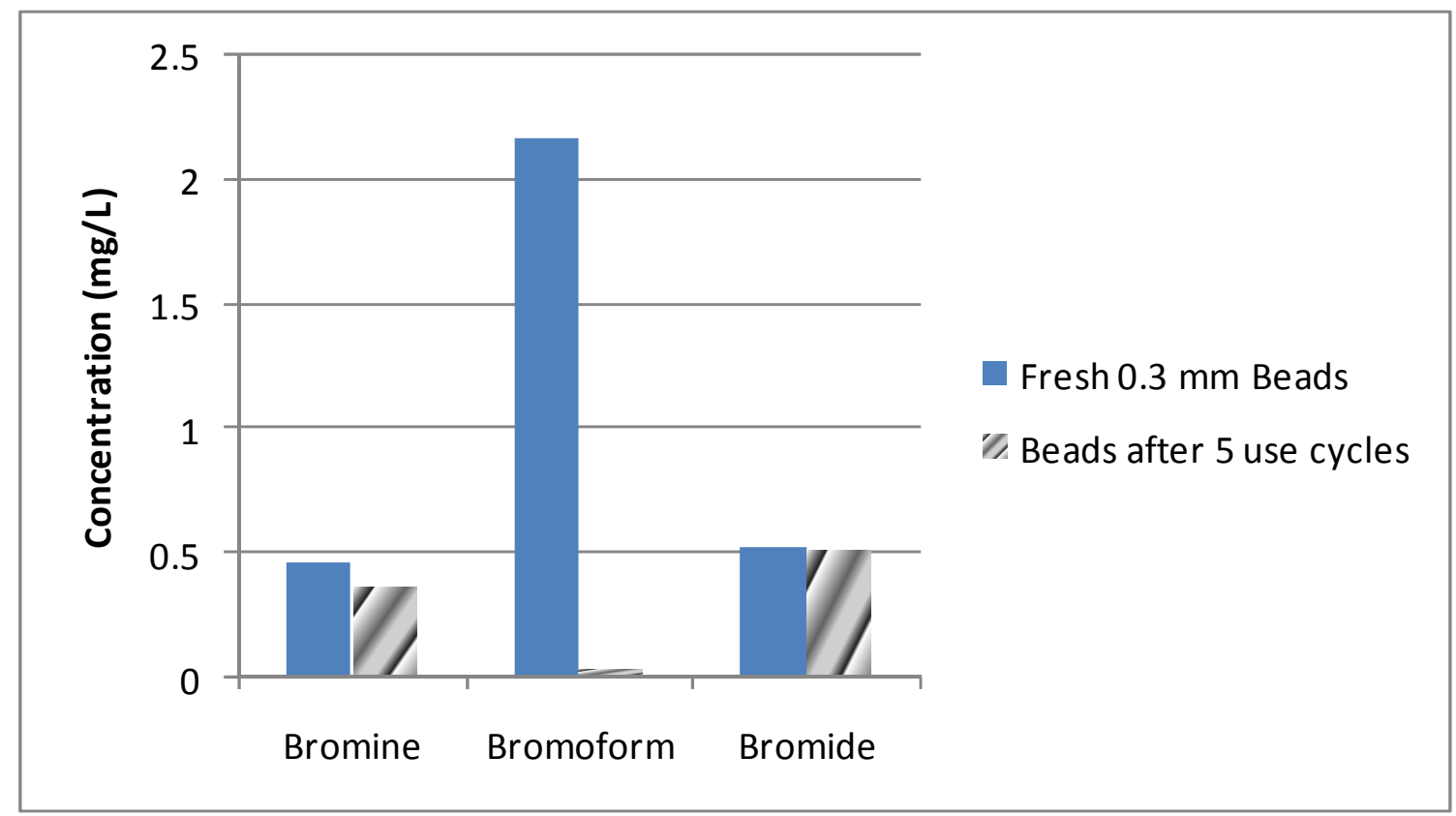

Figure 22. Bromine compound concentrations of fresh $0.3 \mathrm{~mm}$ biocidal bead effluent vs. $0.3 \mathrm{~mm}$ biocidal beads after five siumulated use cylces at $0.56 \mathrm{~mL} / \mathrm{sec}$ flow rate 


\section{Dry Storage}

After 162 days of dry storage, the $0.3 \mathrm{~mm}$ biocidal beads were set in a column and pond water was passed through the beads at $0.56 \mathrm{~mL} / \mathrm{sec}$. The bromine concentration in leachate from these beads was $0.47 \mathrm{mg} / \mathrm{L}$ (Table 25). The concentration of bromine in pond water passed through fresh $0.3 \mathrm{~mm}$ beads was exactly the same (Table16). Thus the $0.3 \mathrm{~mm}$ biocidal beads exhibited no loss of bromine after 162 days of dry storage.

Table 25. Effluent bromine concentrations from $0.3 \mathrm{~mm}$ beads at a flow rate of 0.56 $\mathrm{mL} / \mathrm{sec}$ after 162 days of dry storage

\begin{tabular}{|c|c|}
\hline Sample & Bromine Concentration $(\mathrm{mg} / \mathrm{L})$ \\
\hline Pond 1 & 0.5 \\
\hline Pond 2 & 0.5 \\
\hline Pond 3 & 0.4 \\
\hline Average & 0.47 \\
\hline
\end{tabular}

Bromide was analyzed from the same pond water leachate of the $0.3 \mathrm{~mm}$ beads that were placed in dry storage for over five months, and the effluent actually contained $43 \%$ more bromide than effluent passed through fresh $0.3 \mathrm{~mm}$ beads at the same flow rate. The effluent from fresh $0.3 \mathrm{~mm}$ beads at $0.56 \mathrm{~mL} / \mathrm{sec}$ contained an average bromide concentration of $0.53 \mathrm{mg} / \mathrm{L}$ (Table 19), while effluent from the stored beads contained an average bromide concentration of $0.76 \mathrm{mg} / \mathrm{L}$ (Table 26). 
Table 26. Effluent bromide concentrations from $0.3 \mathrm{~mm}$ beads after 162 days of dry storage

\begin{tabular}{|c|c|c||c|c|}
\hline Sample & Area & Retention Time & $\begin{array}{c}\text { Bromide } \\
\text { Concentration } \\
(\mathrm{mg} / \mathrm{L})\end{array}$ & $\begin{array}{c}\text { Average } \\
\text { Concentration } \\
(\mathrm{mg} / \mathrm{L})\end{array}$ \\
\hline Pond 1a & 0.048 & 7.1 & 0.66 & \multirow{2}{*}{0.76} \\
\hline Pond 1b & 0.063 & 7.13 & 0.86 & \multirow{2}{*}{0.75} \\
\hline Pond 2a & 0.057 & 7.1 & 0.78 & \\
\hline Pond 2b & 0.052 & 7.1 & 0.71 & \\
\hline
\end{tabular}

Leachate from the $0.3 \mathrm{~mm}$ beads that sat in dry storage for 162 days contained approximately $0.06 \mathrm{mg} / \mathrm{L}$ bromoform (Table 27 ). In comparison, the bromoform concentration was $2.45 \mathrm{mg} / \mathrm{L}$ in leachate from fresh $0.3 \mathrm{~mm}$ beads (Table 17).

Table 27. Bromoform concentrations from $0.3 \mathrm{~mm}$ bead effluent at $0.56 \mathrm{~mL} / \mathrm{sec}$ after 162 days of dry storage

\begin{tabular}{|c|c|c|c|c|c|c|c|}
\hline \multirow{3}{*}{ 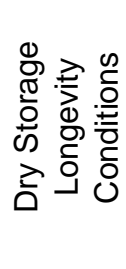 } & $\begin{array}{l}\text { Quenching } \\
\text { Scenario }\end{array}$ & Sample & Area & $\begin{array}{c}\text { Concentration } \\
\text { Factor }\end{array}$ & $\begin{array}{c}\text { Bromoform } \\
\text { Concentration } \\
\text { in Water }(\mathrm{mg} / \mathrm{L})\end{array} \mid$ & $\begin{array}{c}\text { Average } \\
\text { Concentration } \\
(\mathrm{mg} / \mathrm{L})\end{array}$ & $\begin{array}{l}\text { Coefficient } \\
\text { of Variance }\end{array}$ \\
\hline & \multirow{2}{*}{$\begin{array}{c}\text { Quenched } \\
\text { After Sample }\end{array}$} & 1 & 25361 & 19.61 & 0.07 & \multirow{2}{*}{0.06} & \multirow{2}{*}{0.10} \\
\hline & & 2 & 22600 & 20.00 & 0.06 & & \\
\hline
\end{tabular}

In summary, after 162 days of dry storage, pond water effluent from a column of the 0.3 $\mathrm{mm}$ beads contained the same concentration of bromine, nearly $98 \%$ less bromoform, and approximately $30 \%$ more bromide than effluent from fresh $0.3 \mathrm{~mm}$ biocidal beads (Figure 23). Similar to the set of $0.3 \mathrm{~mm}$ beads that underwent five simulated use cycles, the beads that were stored for 162 days also exhibited a drastic reduction in bromoform. The majority of the bromoform appears to have volatilized off the surface of the $0.3 \mathrm{~mm}$ beads. 


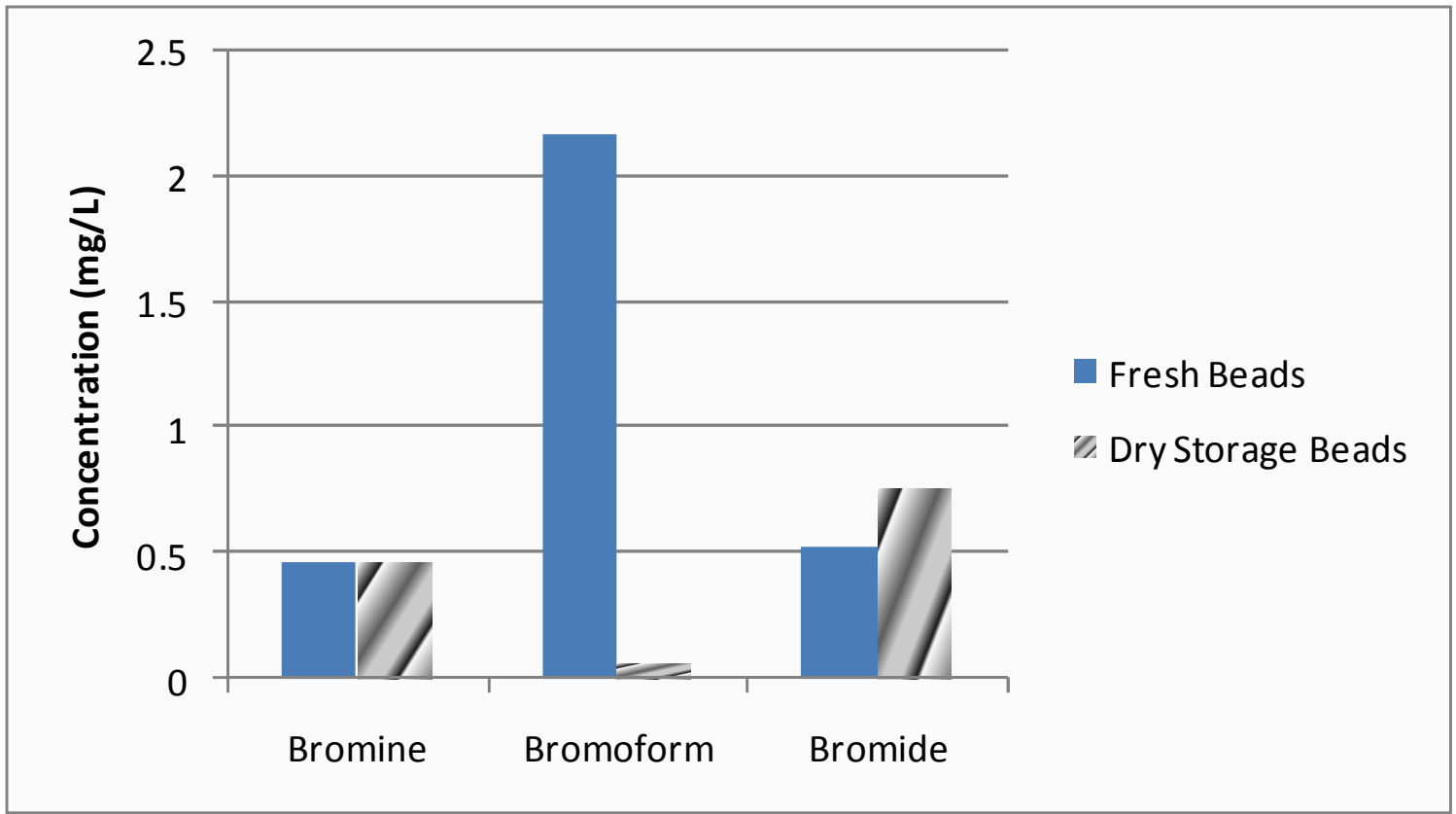

Figure 23. Bromine compound concentrations of fresh $0.3 \mathrm{~mm}$ bead effluent vs. 0.3 $\mathrm{mm}$ bead effluent after 162 days of dry storage at $0.56 \mathrm{~mL} / \mathrm{sec}$ flow rate 


\section{CHAPTER 5: CONCLUSIONS AND RECCOMENDATIONS}

\section{DrainPac ${ }^{\circledR}$ Filter Conclusions}

Maintenance is vital to the efficacy of the DrainPac ${ }^{\circledR}$ filter because solids loading reduces the flow rate at which the filter will be by-passed. The highest filterable flow rate of a DrainPac $^{\circledR}$ filter with dimensions of $12 \times 41$ in. that was loaded with $625 \mathrm{~g}$ of solids was 80 gpm. Head loss data, along with the precipitation characteristics of the specific site for the stormwater filter could be key factors in determining how often routine maintenance of the DrainPac ${ }^{\circledR}$ filters is required.

Compared to past research of the DrainPac ${ }^{\circledR}$ filter (Table 28), the results of this study were most similar to that of Stenstrom (1998). In the present study the average suspended solids removal efficiency of the DrainPac ${ }^{\circledR}$ filter ranged from $83 \%$ to $91 \%$ at various flow rates, compared to 95 to $98 \%$ reported by Stenstrom (Table 28). The higher total suspended solids removal efficiencies reported by Stenstrom, could be due to differences in the solids used for testing. Stenstrom used solids which were removed from catch basins and included sediment and larger items such as cigarette butts, small leaves, and pebbles. In comparison, the solids removed by the DrainPac ${ }^{\circledR}$ were fine sediments in the pond water and sand added to the feed water. In this study, sediment removal efficiency of the filter once it was loaded was not tested. It is possible that higher removal efficiencies could be obtained with a loaded filter if the solids act like a schmutzdecker in a slow-sand filter. Future research could explore the performance of the DrainPac ${ }^{\circledR}$ filter at removing sediments when it is loaded. 
The DrainPac ${ }^{\circledR}$ filter insert removed oil from oil-laden pond water at average efficiencies of $40 \%-82 \%$, which is similar to the $49-86 \%$ oil removal efficiency that Stenstrom (1998) reported (Table 28). There was no apparent trend in oil removal efficiency with flow rate. Solids other than those already present in the pond water were never added during oil removal tests. Future tests could add solids at the same time as the oil to determine the effect of oil adsorption to the solids on the oil removal efficiency of the filter.

Table 28. Studies of the DrainPac ${ }^{\circledR}$ filter

\begin{tabular}{|c|c|c|c|}
\hline Study & Flow Rate & Test & $\begin{array}{c}\text { Removal } \\
\text { Efficiency }\end{array}$ \\
\hline $\begin{array}{c}\text { Morgan et al., } \\
2005\end{array}$ & $207-213 \mathrm{gpm}$ & TSS & 25 \\
\hline \multirow{2}{*}{ Stenstrom, 1998 } & $75 \mathrm{gpm}$ & TSS & $95-98 \%$ \\
\cline { 3 - 4 } & Natural & Oil and grease & $49-86 \%$ \\
\hline Walch et al., & Compared & protected inlets \\
conditions & Vagainst controls & Variable Results \\
\hline \multirow{2}{*}{ This Study } & $20-200$ gpm & Oil and grease & $40-82 \%$ \\
\cline { 3 - 4 }
\end{tabular}

The DrainPac ${ }^{\circledR}$ filter showed no evidence of coliform bacteria removal. This is likely due to the small colloidal size of the bacteria allowing them to pass through the filter fabric. To date, there are no other studies of the coliform bacteria removal efficiency of the DrainPac $^{\circledR}$ filter. Solids were never added during the coliform removal tests, except the solids naturally present in the pond water. Future research could test the coliform removal efficiency of a loaded filter and also test coliform removals while adding 
sediment-laden water to an unloaded filter to determine if the accumulation of solids in the filter has any effect on the coliform removal efficiency of the filter.

\section{Conclusions for Leachate from Biocidal Beads}

The time at which leachate samples were quenched with sodium thiosulfate was found to have drastic effects on bromoform concentrations in leachate from the biocidal beads.

Past studies such as Chen et al. (2003) quenched samples with $0.02 \mathrm{~N}$ sodium thiosulfate, however, the time elapsed before quenching was not reported. Quenching samples after the collection of the total sample was probably the most realistic in terms of typical scenarios for real stormwater because there is usually some contact time in catch basins before discharge to receiving waters. Thus, it is most appropriate to use the leachate concentrations in samples quenched accordingly for predicting bromoform concentrations in the leachate from biocidal beads in a stormwater filter. Higher bromoform concentrations were generally found in samples quenched after the collection of the total sample, followed by samples quenched immediately. Samples quenched after ten minutes usually contained the lowest bromoform concentrations. More research is needed to determine the full effects of time elapsed before quenching samples on bromoform concentrations in the leachate.

The $0.3 \mathrm{~mm}$ biocidal beads leached more bromine compounds than the $0.8 \mathrm{~mm}$ beads, particularly bromoform. The greater leaching from the smaller beads can be partly explained by the greater surface area of a $1-\mathrm{cm}$ bed of the $0.3 \mathrm{~mm}$ beads. The surface area in a 1-cm diameter column packed with a $1-\mathrm{cm}$ depth of $0.3 \mathrm{~mm}$ beads is nearly 4 
times greater than the same column packed with a 1-cm depth of $0.8 \mathrm{~mm}$ beads, allowing for more mass transfer of bromine. This could explain the higher bromine concentrations in leachate from the $0.3 \mathrm{~mm}$ beads, which was $43 \%$ higher than for the $0.8 \mathrm{~mm}$ beads at a test flow rate of $0.56 \mathrm{~mL} / \mathrm{sec}$. However, $98 \%$ higher bromoform concentrations were observed for the $0.3 \mathrm{~mm}$ beads compared to the $0.8 \mathrm{~mm}$ beads, and this cannot be explained by greater surface area alone. This large amount of bromoform leaching was most likely due to the different manufacturing process used for the $0.3 \mathrm{~mm}$ beads. According to the manufacturer, the new $0.8 \mathrm{~mm}$ beads are made using different conditions which dramatically reduced the bromoform leaching from the beads. The manufacturer has discontinued production of the $0.3 \mathrm{~mm}$ brominated beads.

The source of the bromoform can be better understood by considering the chemistry of bromoform formation. As bromine leaches into the water, it is expected to react with organics present in the water and be reduced to bromide, forming bromoform (Westerhoff, et al., 2004). However, DI flush water that passed through a 1-cm bed of $0.3 \mathrm{~mm}$ beads at $0.28 \mathrm{~mL} / \mathrm{sec}$ contained $1.25 \mathrm{mg} / \mathrm{L}$ bromoform, even though no organics are present in DI water. This suggests that bromoform was already on the surface of the $0.3 \mathrm{~mm}$ beads. In contrast, the concentration of bromoform in DI flush water passed through $0.8 \mathrm{~mm}$ beads at the same flow rate was below detection. Therefore the new manufacturing process used for the $0.8 \mathrm{~mm}$ beads appears to have greatly reduced or eliminated the bromoform on the beads. Further, it was found that there was a 97\% reduction of bromoform in the leachate of $0.3 \mathrm{~mm}$ beads after the beads were stored dry for 162 days. Thus bromoform on the surface of the $0.3 \mathrm{~mm}$ beads, appears to have volatilized during dry storage. 
Although the $0.8 \mathrm{~mm}$ beads do not appear to have free bromoform on their surfaces, there is some bromoform formed by reaction of free bromine with organic material in the leachate. Pond water leachate from a $1-\mathrm{cm}$ bed of $0.8 \mathrm{~mm}$ beads contained an average bromine concentration of $0.27 \mathrm{mg} / \mathrm{L}$, an average bromoform concentration of $0.06 \mathrm{mg} / \mathrm{L}$, and an average bromide concentration of $0.5 \mathrm{mg} / \mathrm{L}$. Similar to Chen et al. (2003), the leachate contained less than $2.0 \mathrm{mg} / \mathrm{L}$ bromine. The bromoform concentrations in the leachate from the $0.8 \mathrm{~mm}$ beads were lower than the bromoform drinking water maximum contaminant level of $80 \mu \mathrm{g} / \mathrm{L}$ (U.S. EPA, 2008c).

Higher bromine compound concentrations were found at lower flow rates, likely because of the longer retention time in contact with the beads. Longer retention times allow for more mass transfer of bromine compounds. Leachate from $0.8 \mathrm{~mm}$ beads contained $64 \%$ higher bromide concentrations at a flow rate of $0.28 \mathrm{~mL} / \mathrm{sec}$ compared to a flow rate of $0.56 \mathrm{~mL} / \mathrm{sec}$.

Slight reductions in bromine and bromide concentrations were found in leachate from the $0.3 \mathrm{~mm}$ beads that underwent five simulated use cycles compared to leachate from fresh beads. A 99\% reduction in bromoform was found after five simulated use cycles. This drastic reduction in bromoform formation suggests that much of the bromoform is exhausted early on. The longevity of bromine in the leachate from the biocidal beads was only tested for the $0.3 \mathrm{~mm}$ beads. Future research could test the $0.8 \mathrm{~mm}$ biocidal beads after each simulated use cycle to determine the rate of bromoform exhaustion so that, if needed, the beads could be pre-rinsed to decrease the amount of bromoform leaching from the beads before use in actual catchment basins. The biocidal beads tested in this study seem promising for stormwater treatment in catchment basins, however, more 
research is needed to determine if the bromine compound concentrations in the leachate would have any negative effects on aquatic habitats. 


\section{REFERENCES}

American Public Health Association. (1999a). Standard methods for the examination of water and wastewater (Partition-Gravimetric Method, 5520 B.), 20th Edition. American Public Health Association, Washington, DC.

American Public Health Association. (1999b). Standard methods for the examination of water and wastewater (Trihalomethanes and Chlorinated Organic Solvents, Method 6232), 20th Edition. American Public Health Association, Washington, DC.

American Public Health Association. (1999c). Standard methods for the examination of water and wastewater (Total Suspended Solids Dried at $103-105^{\circ} \mathrm{C}$, Method \#2540 D), 20th Edition. American Public Health Association, Washington, DC.

Booth, D. B. and Jackson, C. R., (1997). "Urbanization of aquatic systems: degradation of thresholds, stormwater detection, and the limits of mitigation." Journal of the American Water Resources Association 33: 5 pp. 1077-1090.

Booth, D. B., Hartley, D., and Jackson, R., (2002). "Forest Cover, Impervious-Surface Area, and the Mitigation of Stormwater Impacts." Journal of the American Water Resources Association 38: 3 pp. 835-845.

Bratieres, K., Fletcher, T.D., Deletic, A., and Zinger, Y. (2008). "Nutrient and sediment removal by stormwater biofilters: A large-scale design optimization study." Water Research 42, pp. 3930-3940.

Brezonik P. L. and Stadelmann, T. H. (2002). “Analysis and Predictive Models of stormwater runoff volumes, loads, and pollutant concentrations from watersheds in the Twin Cities metropolitan area, Minnesota, USA." Water Research 36, pp. 17431757.

Brinkmann, W.L.F. (1983). "Dissolved and suspended loads of the regulated River Nidda in the Rhine-Main area." Proceedings of the Hamburg Symposium on dissolved loads of rivers and surface water quantity/quality relationship. IAHS Publ. no. 141,347-357

Brinkmann, W. L. F. (1985). "Urban Stormwater pollutants: Sources and Loadings." GeoJournal 11:3, pp. 277-283.

Carleton, J. N., Grizzard, T. J., Godrej, A. N., Post, H. E., Lampe, L., and Kenel, P. P. (2000). "Performance of a Constructed Wetlands in Treating Urban Stormwater Runoff." Water Environment Research 72, pp. 295-304.

Casson, L. W., Hunter, G. L., and Bess, J. W. Jr. (2006). “The Challenge of the Future: Operating Emerging Disinfection Technologies." Water Environment Federation. WEFTEC 2006. 
Chen, Y., Worley, S. D., Kim, J., Wei, C. -I., Chen, T., Santiago, J. I., Williams, J. F., and Sun, G. (2003). "Biocidal Poly(styrenehydantoin) Beads for Disinfection of Water." Ind. Eng. Chem. Res. 42, pp. 280-284.

Chen, Y., Worley, S. D., Huang, T. S., Weese, J., Kim, J., Wei, C.-I., and Williams, J.F. (2004a). "Biocidal Polystyrene Beads. III. Comparison of N-halamine and Quat Functional Groups.” Journal of Applied Polymer Science 92, pp. 363-367.

Chen, Y., Worley, S. D., Huang, T. S., Weese, J., Kim, J., Wei, C.-I., and Williams, J. F. (2004b). "Biocidal Polystyrene Beads. IV. Functionalized Methylated Polystryene." Journal of Applied Polymer Science 42, pp. 368-372.

Chiras, Daniel, D. Environmental Science, Seventh Edition. Sudbury, MA: Jones \& Bartlett, 2006.

Dietz, M. E. and Clausen, J. C. (2008). "Stormwater runoff and export changes with development in a traditional and low impact subdivision." Journal of Environmental Management 87: 4, pp. 560-566.

Devinny, J. S., Kamieniecki, S., and Stenstrom, M. (2005). Alternative Approaches to Stormwater Quality Control, Center for Sustainable Cities, University of Southern California, Los Angeles, CA.

Field, R., O'Shea, M., and Brown, M. P. (1993). "The Detection and Disinfection of Pathogens in Storm-Generated Flows." Water Science and Technology 28: 3-5, pp. 311-315.

Geankoplis, Christie, J. Transport Processes and Separation Processes Principles, Fourth Edition. Upper Saddle River, NJ: Prentice Hall, 2003.

Hascic I. and Wu JJ (2006). "Land use and watershed health in the United States." Land Econ 82:2, pp. 214-39.

Hatt, B.E., Deletic, A., and Fletcher, T.D. (2007). "Stormwater reuse: designing biofiltration systems for reliable treatment." Water Science and Technology 55: 4, 201-209.

He, L.M. and He, Z.L. (2008). "Water quality prediction of marine recreational beaches receiving watershed baseflow and stormwater runoff from southern, California, USA." Water Research 42, pp. 2563-2573.

Henderson, C., Greenway, M., and Phillips, I. (2007). "Removal of dissolved nitrogen, phosphorus and carbon from stormwater by biofiltration mesocosms." Water Science and Technology 55: 4, pp. 183-191.

Hipp, J. A., Ogunseitan, O., Lejano, R., and Smith, C. S., (2006) "Optimization of Stormwater Filtration at the Urban/Watershed Interface." Environmental Science \& Technology 40: 15 pp. 4794-4801. 
Horner, Richard (1993). "Constructed Wetlands for Urban Water Quality Control”. EPA Seminar Publication. National Conference on Urban Runoff Management: Enhancing Urban Watershed Management at the Local, County, and State Levels. March 30 to April 2, 1993. The Westin Hotel. Chicago, Illinois.

Horner, R. R. and C. W. May (1999). Regional Study Supports Natural Land Cover Protection as Leading Best Management Practice for Maintaining Stream Ecological Integrity. In: Comprehensive Stormwater and Aquatic Ecosystem Management, Conference Papers. New Zealand Water and Wastes Association, pp. 233-247.

Kayhanian, M., Hollingsworth, L., Spongberg, M., Regenmorter, L. C., and Tsay, K. (2002). "Characteristics of Stormwater Runoff from Caltrans Facilities". Presented at: Transportation Research Board, 81st Annual Conference, Washington, D.C., Jan.1317, 2002 (included in conference proceedings).

Lee, J. H. and Bank, K. W. (2000). "Characterization of Urban Stormwater Runoff." Water Research 34: 6, pp. 1773-1780.

Lee, H., Lau, S., Kayhanian, M., and Stenstrom, M.K. (2004). "Seasonal First Flush Phenomenon of Urban Stormwater Discharges." Water Research 38, pp. 4153-4163.

Lehner, P. H., Aponte Clark, G. P., Cameron, D. M., and Frank, A. G. (2001). "Stormwater Strategies: Community Responses to Runnoff Pollution." National Resources Defense Council. October 2001. Retrieved December 29, 2008 from: http://www.nrdc.org/water/pollution/storm/chap12.asp

Metcalf and Eddy, Tchobanoglous, G., Burton, F.L., and Stensel, H.D. (2003). Wastewater Engineering: Treatment and Reuse. 4th Eddition. McGraw HIl ISBN-13: 978-0-07-041878-3.

Morgan, R. A., Edwards, F. G., Brye, K. R., and Burian, S. J. (2005). “An Evaluation of the Urban Stormwater Pollutant Removal Efficiency of Catch Basin Inserts." Water Environment Research 77: 5, pp. 500-510.

Murakami, M., Sato, N., Anegawa, A., Nakada, N., Harada, A., Komatsu, T., Takada, H., Tanaka, H., Ono, Y., and Furumai, H. (2008). "Multiple Evaluations of the Removal of Pollutants in Road Runoff by Soil Infiltration." Water Research 42: 10-11, pp. 2745-2755.

Noble, R.T., Dorsey, J. H., Leecaster, M., Orozco-Borbon, V., Reid, D., Schiff, K., and Weisberg, S.B. (2000). "A Regional Survey of the Microbiological Water Quality along the Shoreline of the Southern California Bight." Environmental Monitoring and Assessment 64, pp. 435-447.

Stenstrom, M. (1998). UCLA DrainPac test paper--- UCLA 1998. letter from Dr. Michael Stenstrom, UCLA Prof Civil Eng. to Mr. Paul Corn of United Pumping Services (manufacturer of Drain Pac Filters) detailing results of lab tests performed on Drain Pac Filters. September 25. 
Stormceptor $^{\circledR}$ website. Retrieved December 29, 2008.

http://www.stormceptor.ca/index.html

Sun, G., Allen, L. C., Luckie, E. P., Wheatley, W. B., and Worley, S. D. (1995)

"Disinfection of Water by N-Halamine Biocidal Polymers." Ind. Eng. Chem. Res. 34, pp. 4106-4109.

Sun, G., Chen, T. Y., Habercom, M. S., Wheatley, W. B., and Worley, S. D. (1996). "Performance of a New Polymeric Water Disinfectant." Water Resources Bulletin 32: 4, pp. 793-797.

Thomas, V. K., Realey, G. J., and Harrington, D. W. (1990). "Disinfection of Sewage, Stormwater and Final Effluent." Water and Environment Journal 4: 5 pp. 422-429.

Unified Soil Classification System. ASTM D2487-00 Standard Classification of Soils for Engineering Purposes.

U.S. Environmental Protection Agency (2008a). Low Impact Development. Retrieved December 29, 2008 from EPA website: http://www.epa.gov/nps/lid/

U.S. Environmental Protection Agency (2008b). National Pollutant Discharge System. Retrieved December 28, 2008 from EPA website: http://cfpub.epa.gov/npdes/stormwater/swbasicinfo.cfm

U.S. Environmental Protection Agency (1999). Preliminary Data Summary of Urban Stormwater Best Management Practices. Chapter 4.2 Pollutants in Urban Stormwater. Retrieved February 3, 2009 from EPA website: http://www.epa.gov/guide/stormwater/files/usw_b.pdf

U.S. Environmental Protection Agency (2004). Report to Congress: Impacts and Control of CSOs and SSOs, April 26, 2004, EPA 833-R-04-001, p. 4-29. Retrieved January 15, 2009 from EPA website: http://cfpub.epa.gov/npdes/cso/cpolicy_report2004.cfm.

U.S. Environmental Protection Agency (2008c). Central Valley Regional Water Quality Control Board: Water Quality Goals for Bromoform. Water Quality Goals Database.

Vassilios, T.A. and Hamid, R. (1997). "Modeling and Management of Urban Stormwater Runoff Quality: A Review” Water Resources Management 11:2 pp. 136-164.

Walch, M., Cole, R., Polasko, W., Walters, D., Frost, W., DiNicola, P., and Gneo, R. (2004). "Evaluation of the Performance of Four Catch Basin Inserts in Delaware Urban Applications." Delaware Department of Transportation. Retrieved January 4, 2009. http://www.deldot.gov/stormwater/pdfs/StormCon04_Walch.pdf

Westerhoff, P., Chao, P., and Mash, H. (2004). "Reactivity of Natural Organic Matter with Aqueous Chlorine and Bromine.” Water Research 38:6, pp. 1502-1513.

Worley, S. D., Sun, G., Sun, W., and Chen, T. Y. (1996). Polymeric Cyclic N-Halamine Biocidal Compounds. U.S. Patent 5,490,983. 


\section{APPENDIX A}

Table A-1. Bromide standard data for $0.8 \mathrm{~mm}$ bead run

\begin{tabular}{|c|c|c|c|}
\hline $\begin{array}{c}\text { Standard } \\
\text { Concentration } \\
(\mathrm{mg} / \mathrm{L})\end{array}$ & Area & $\begin{array}{l}\text { Retention } \\
\text { Time }\end{array}$ & $\begin{array}{c}\text { Average } \\
\text { Area }\end{array}$ \\
\hline \multirow{2}{*}{0.25} & 0.021 & 7.07 & \multirow{2}{*}{0.021} \\
\hline & 0.020 & 7.10 & \\
\hline \multirow{2}{*}{0.5} & 0.047 & 7.08 & \multirow{2}{*}{0.045} \\
\hline & 0.042 & 7.10 & \\
\hline \multirow{2}{*}{0.75} & 0.071 & 7.12 & \multirow{2}{*}{0.072} \\
\hline & 0.073 & 7.10 & \\
\hline \multirow{2}{*}{1} & 0.091 & 7.12 & \multirow{2}{*}{0.093} \\
\hline & 0.094 & 7.10 & \\
\hline \multirow[b]{2}{*}{2} & 0.181 & 7.15 & \multirow[b]{2}{*}{0.187} \\
\hline & 0.193 & 7.12 & \\
\hline
\end{tabular}

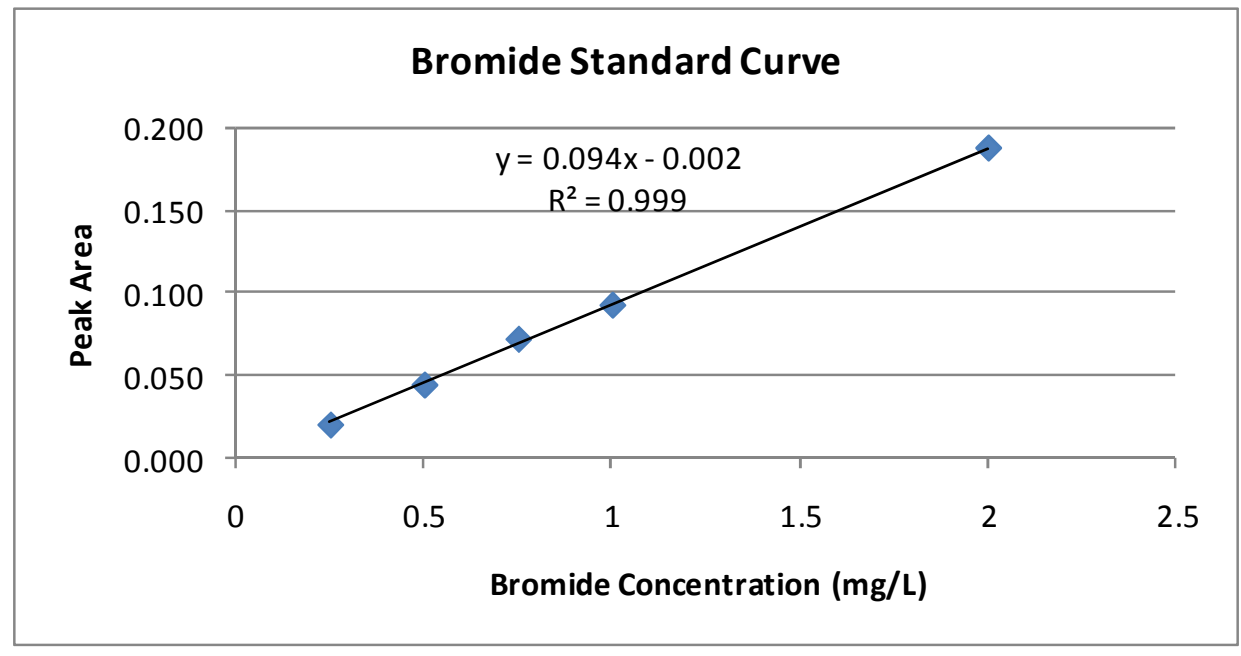

Figure A-1. Bromide standard curve for $0.8 \mathrm{~mm}$ bead run 


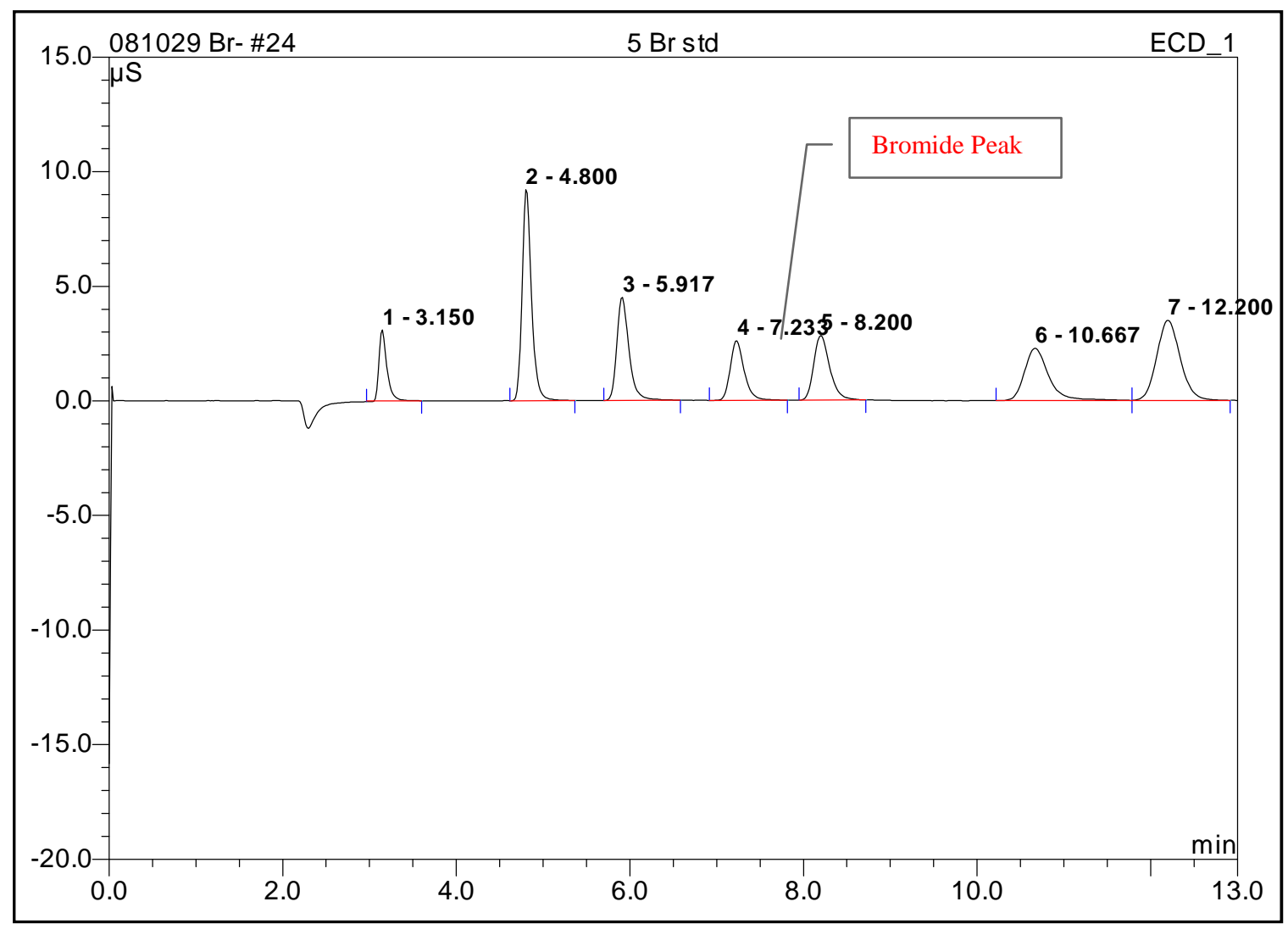

Figure A-2. $5 \mathrm{mg} / \mathrm{L}$ bromide standard ion chromatogram 


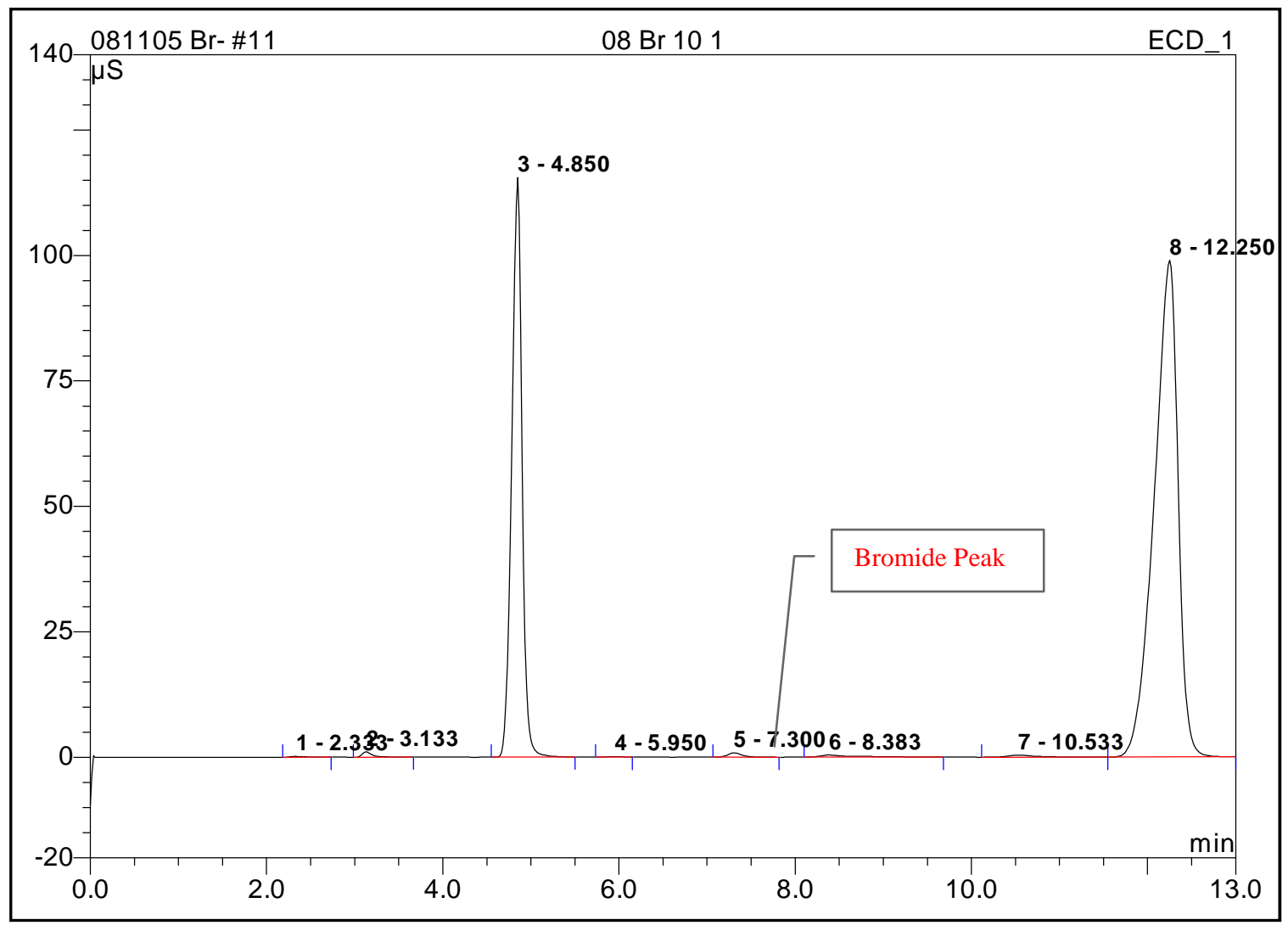

Figure A-3. Ion chromatogram of leachate from $0.8 \mathrm{~mm}$ beads at $0.28 \mathrm{~mL} / \mathrm{sec}$ - pond water sample contained $1.8 \mathrm{mg} / \mathrm{L}$ bromide

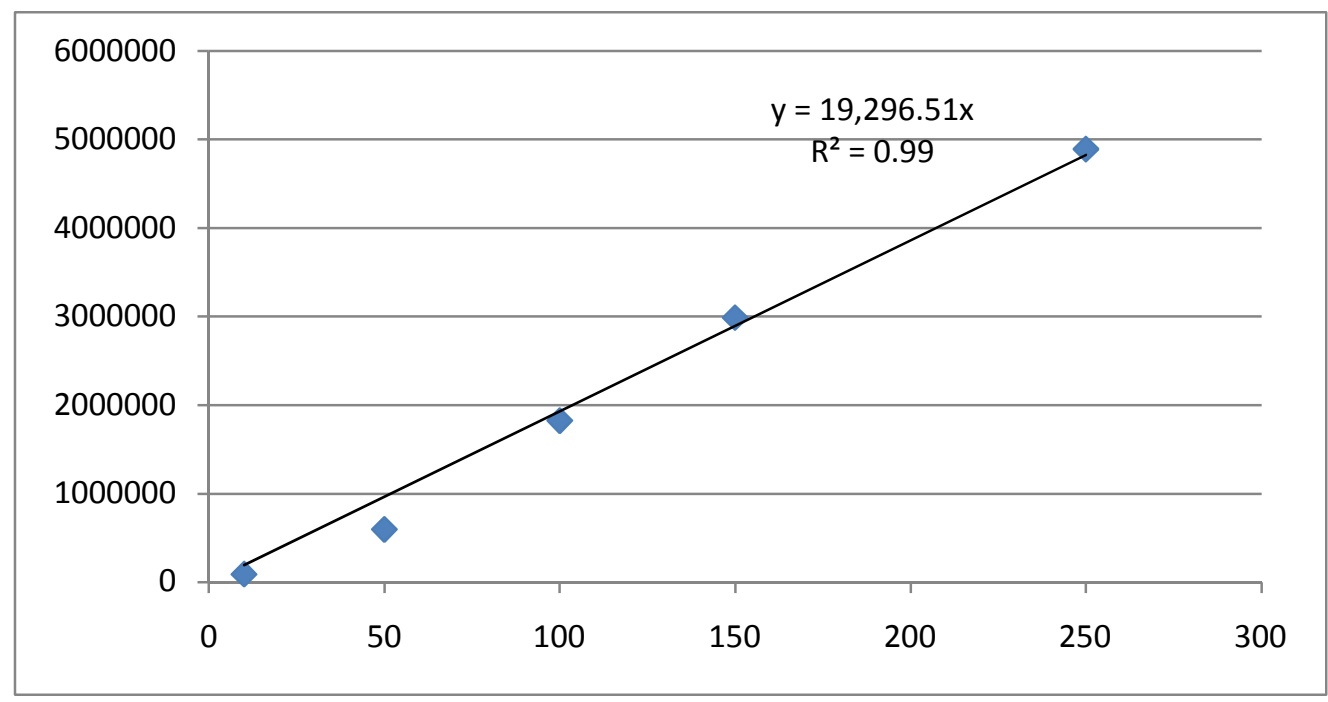

Figure A-4. Bromoform standard curve for dry storage beads 